Portland State University

PDXScholar

Spring 9-22-2017

\title{
Turbidity Dynamics during High-Flow Storm Events in the Clackamas River, Oregon 2006-2012
}

Micelis Clyde Doyle

Portland State University

Follow this and additional works at: https://pdxscholar.library.pdx.edu/open_access_etds

Part of the Hydrology Commons, and the Water Resource Management Commons Let us know how access to this document benefits you.

\section{Recommended Citation}

Doyle, Micelis Clyde, "Turbidity Dynamics during High-Flow Storm Events in the Clackamas River, Oregon 2006-2012" (2017). Dissertations and Theses. Paper 3884.

https://doi.org/10.15760/etd. 5772

This Thesis is brought to you for free and open access. It has been accepted for inclusion in Dissertations and Theses by an authorized administrator of PDXScholar. Please contact us if we can make this document more accessible: pdxscholar@pdx.edu. 
Turbidity Dynamics during High-Flow Storm

Events in the Clackamas River, Oregon 2006-2012

by

Micelis Clyde Doyle

A thesis submitted in partial fulfillment of the requirements for the degree of

\author{
Master of Science \\ In \\ Environmental Science and Management
}

Thesis Committee:

Heejun Chang, Chair

J. Alan Yeakley

Yangdong Pan

Portland State University

2017 


\section{Abstract}

Turbidity is a useful parameter that can be utilized to help understand the water quality in a river and is an expression of the optical properties of a liquid that cause light rays to be scattered and absorbed rather than transmitted in straight lines. A total of 41 storm events occurring during water years 2006-2012 were analyzed for this study. A hysteresis index ( $\mathrm{HI})$ was used to assess the difference in turbidity on the rising and falling limbs of a storm-hydrograph. The upstream Carter Bridge site exhibited a clockwise (C) hysteresis in 38 of 41 storm events and counter-clockwise (CC) hysteresis in three storm events. The downstream Oregon City site exhibited clockwise hysteresis in 29 of 41 storm events and counter-clockwise hysteresis in 12 storm events. Paired ttest comparisons of calculated $\mathrm{HI}$ measured during storm events showed that the upstream forested site Carter Bridge had a statistically significant higher HI than the downstream Oregon City site, suggesting that particles that contribute to increasing turbidity and suspended sediment at the upstream site are delivered to the river earlier in the storm event in comparison to the downstream Oregon City site. In contrast particulate matter and suspended sediment was more likely to be higher on the receding limb of the storm hydrograph at the downstream site in comparison to the upstream monitoring location.

Multiple linear regression analysis determined the major hydrological controls influencing turbidity over the period of a storm event. The log value of the change (Log 
$\Delta \mathrm{Q}$ ) in discharge explained $81 \%$ of the log value of change in turbidity (Log $\Delta T \mathrm{~Tb}$ ) at Carter Bridge and $48 \%$ of the change in turbidity at Oregon City for all storms. Log $\Delta Q$ explained $85 \%$ and $50 \%$ variations of $\log \Delta \mathrm{Tb}$ at Carter Bridge and at Oregon City, respectively in the wet season. Log $\Delta \mathrm{Q}$ explained $82 \%$ of Log $\Delta \mathrm{Tb}$ at Carter Bridge during the Dry Season and together with 3-day antecedent precipitation, Log $\Delta \mathrm{Q}$ explained $84 \%$ of variation in Log $\Delta T b$ at Oregon City during the Dry Season. The findings of this study, which offers information about the dynamics that lead to increased turbidity events, could be helpful to researchers, regulatory agencies and water resource managers in maintaining high water quality in rivers. 


\section{Dedication}

I would like to dedicate this thesis to my immediate family Kate, Malik and Mia who had to deal with me typing away in my office when they wanted to spend time with me.

They certainly need to understand that the feeling was mutual and I will make up for it. I would also like to dedicate this to my friends and family that continued to support me and give me encouragement throughout this long process. I could not have done this without all of you. 


\section{Acknowledgments}

I would like to thank my advisor, Dr. Heejun Chang for his support, wisdom and patience. I was fortunate to have such and excellent advisor in so many facets. I owe him considerably as he helped me through this process. I would also like to thank my other committee members Dr. Alan Yeakley and Dr. Yangdong Pan for their assistance and counsel throughout this process. Their critique really helped me improve the quality of my project. I really appreciated their positive encouragement as well.

I would also like to thank my colleagues at the U.S. Geological Survey that supported me thorough the entire process. Although there were many I would like to thank Stewart Rounds, Joe Rinella, Kathy McCarthy, Ian Waite, Jackie Olsen, for their assistance and continual support during my entire graduate school experience. 


\section{Table of Contents}

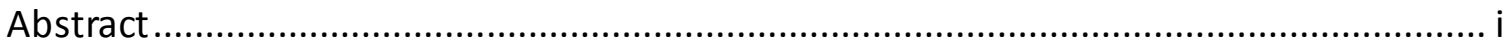

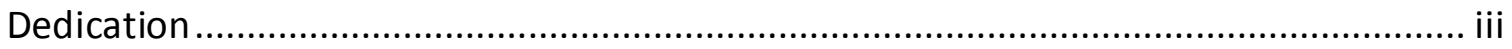

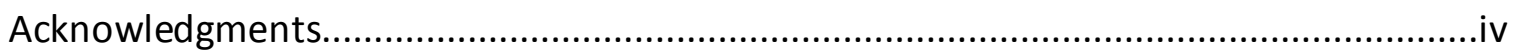

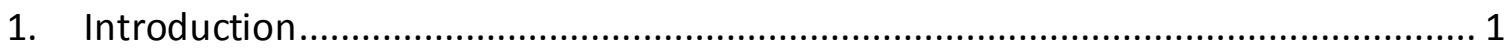

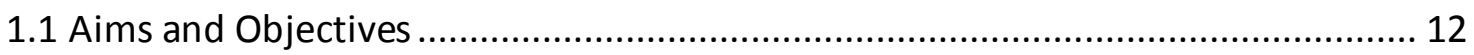

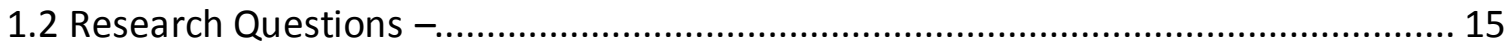

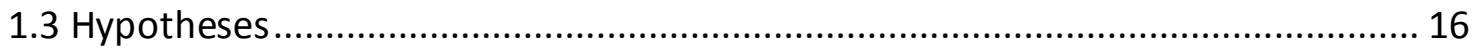

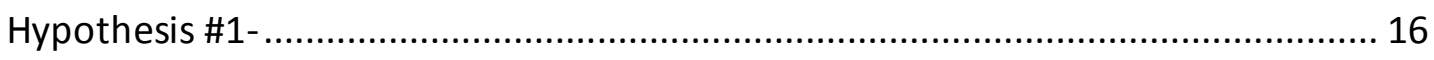

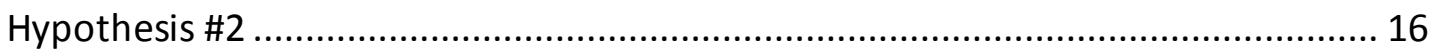

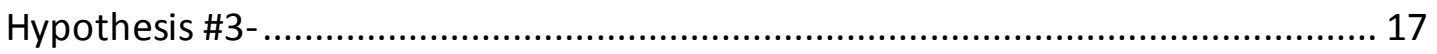

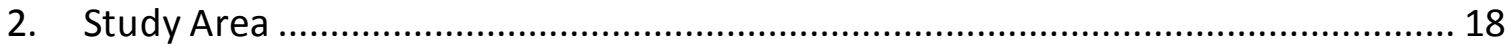

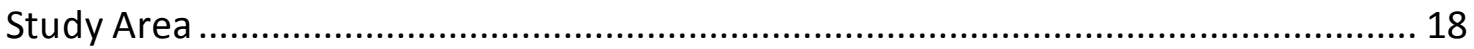

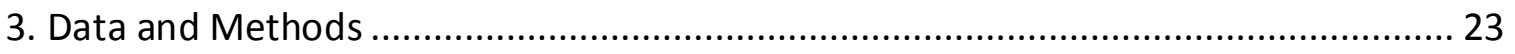

3.1 Data

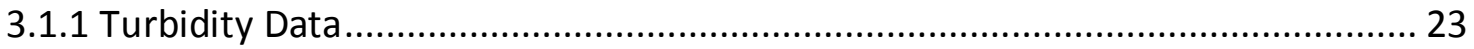

3.1.2 Discharge Data.......................................................................................... 25

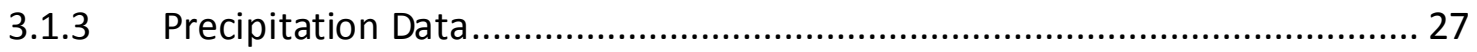

3.1.4 Clackamas Basin Land Cover Data................................................................. 27

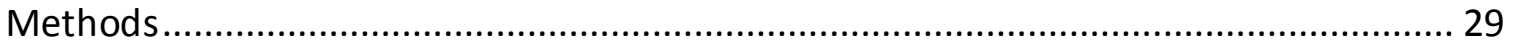

3.1 Wet Season and Dry Season Period Delineation.................................................. 29

3.2.2 Storm Selection and Identification................................................................... 31

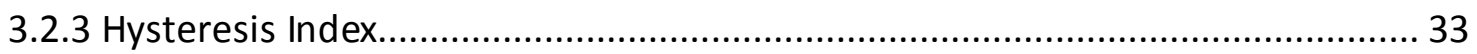

3.2.4 Antecedent Hydro-meteorological Conditions ..................................................... 36

3.2.5 GIS Land Cover Data Analysis along River Channel ........................................... 37

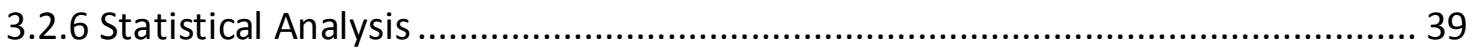

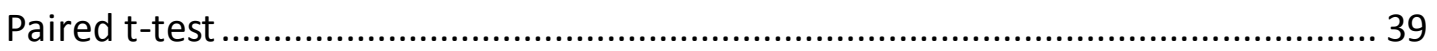

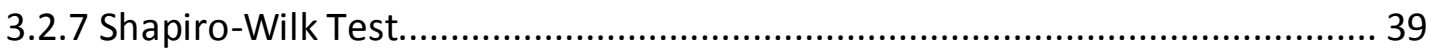

3.2.8 Regression analysis ..................................................................................... 40 


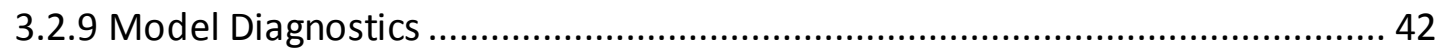

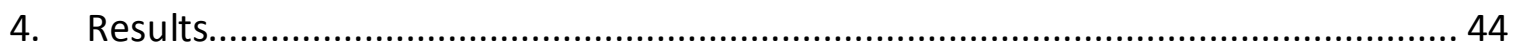

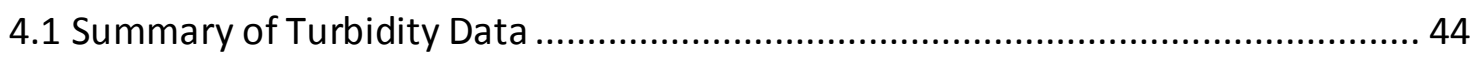

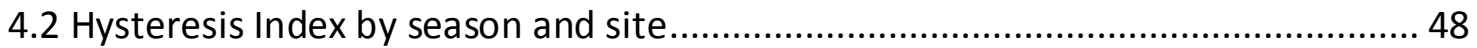

Land Cover Characterization within 100 and 200 Meter Buffer Zones of Clackamas

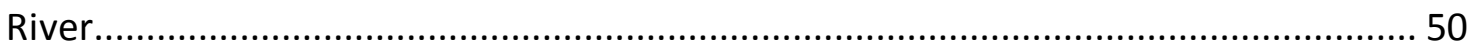

4.3 Relation between discharge and turbidity ................................................. 53

4.6 Model Diagnostics for both sites.............................................................. 58

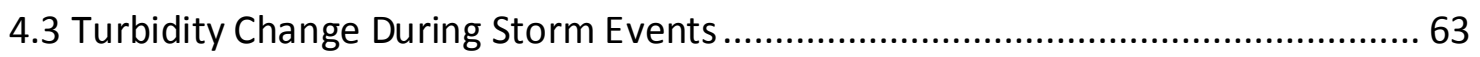

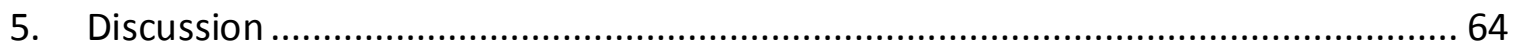

5.1 Relation between land cover and hysteresis patterns...................................... 65

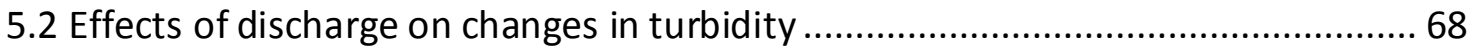

5.3 Implications for water management and potential model improvement............. 69

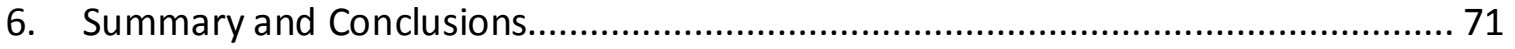

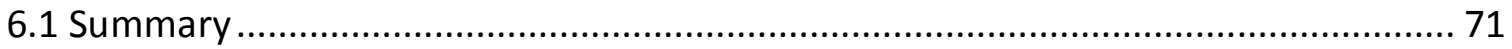

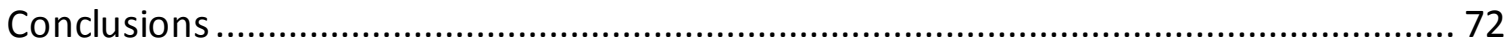

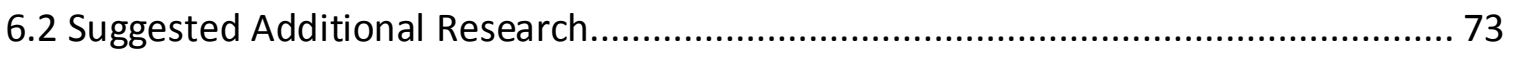

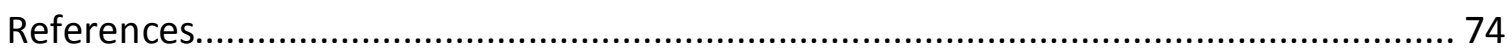

Appendices

Appendix A-Statistical Summary of Turbidity and Discharge Data for Clackamas at

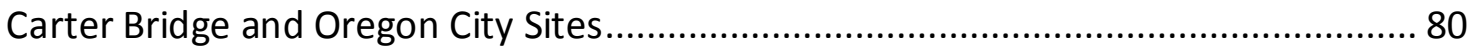

Appendix B-Annual Precipitation Data Summary Measured at Clackamas at Three Lynx for Water Years 2006-2012 ............................................................................... 81

Appendix C-Annual Precipitation Data Summary at Three Lynx and Oregon City for

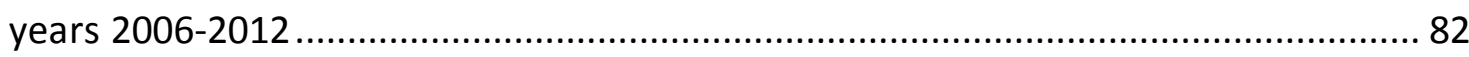

Appendix D-Summary and Statistical Information of Wet Season and Dry Season

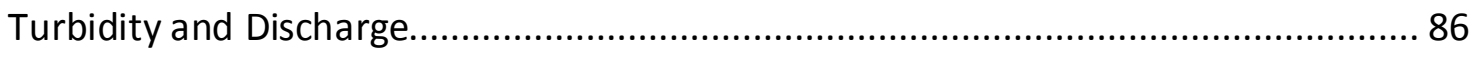

Appendix E-Hysteresis Indices for Carter Bridge................................................... 88

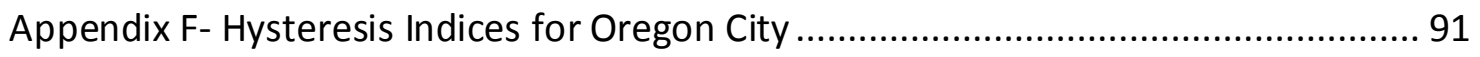


Appendix G-Shapiro-Wilk Test for Normality Results for Change in Turbidity Final

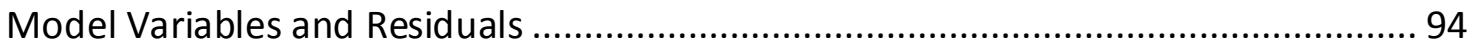




\section{LIST OF TABLES}

Table

Page

Table 1. Representative studies investigating turbidity dynamics, hysteresis and suspended sediment during storm events

Table 2. Latitude and Longitude coordinates of water quality (including turbidity), discharge monitoring stations and precipitation measuring stations.

Table 3. Comparison of basin characteristics between Clackamas above Three Lynx and Clackamas at Carter Bridge sites........................................................................ 26

Table 4. Land Cover Information for Carter Bridge and Oregon City Watersheds ...... 28

Table 5. Independent variables used for model development ................................... 42

Table 6. Statistical Summary of Hysteresis Indices Calculated at Study Sites ............ 49

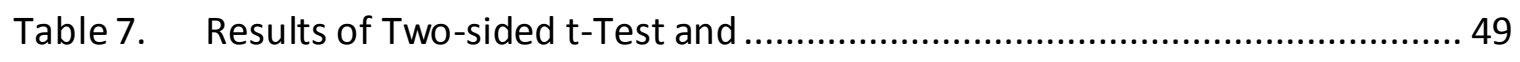

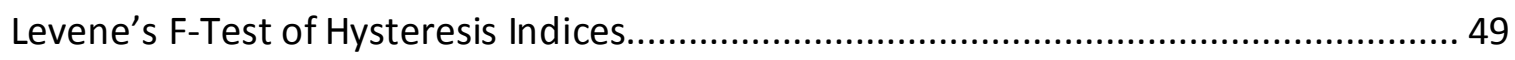

Table 8. Percentage of Land Cover Classifications within 100-meter and 200-meter Buffer Regions of the Clackamas River at Carter Bridge and Oregon City based on 2011

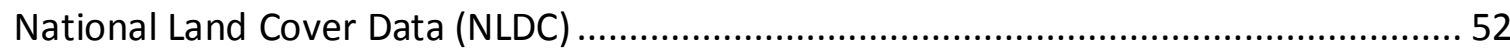

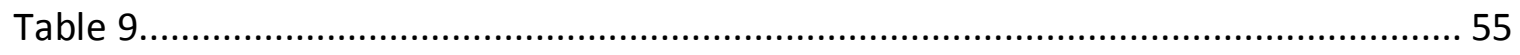

Data used for Carter Bridge Multiple Linear Regression Analysis-............................... 55

Table 10. Data used for Oregon City Multiple Linear Regression Analysis ................ 56

Table 11. Change in Turbidity Model Summary .................................................. 57

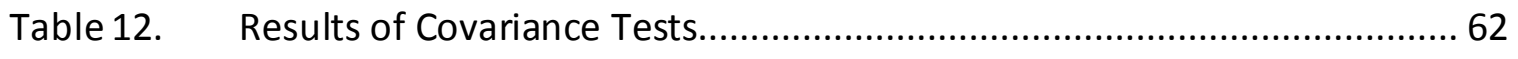




\section{LIST OF FIGURES}

Figure

Page

Figure 1. Conceptual model of elements that contribute to increased turbidity during storm events

Figure 2. Map of Clackamas River Basin showing water-quality monitors, stream discharge gauging sites and precipitation stations.

Figure 3. Schematic of how turbidity sensor operates 25

Figure 4. Hyetograph showing monthly average rainfall amount and standard deviation for water years 2006-2012 measured at Clackamas above Three Lynx, Oregon Precipitation Station, (Data from National Climate Data Center (NCDC), Carbon Dioxide Information Analysis Center (CDIAC) and Oak Ridge National Laboratory, Oak Ridge, Tennessee), $\mathrm{mm}=$ millimeters 30

Figure 5. An example of a storm hydrograph and turbidity at Carter Bridge and Oregon City showing baseflow preceding and following a storm event

Figure 6. Example of "Wet Season Storm 2012.4" storm events hydrograph and turbidity graphs. FNU=Formazin Nephelometric Units, CMS=cubic meters per second . 33

Figure 7. Example diagram using data from storm event at Oregon City occurring from 3/38/2010 to 4/2/2010 (event \# 2010.4), showing points on hydrograph where concurrent turbidity values measured at specific discharges points during an event were used to calculate a hysteresis index (HI). Qmin =the discharge prior to the rise in the hydrograph preceding the event; Qmid = the discharge at the midpoint between , Qmin and Qmax = the peak discharge during the event; FNU=Formazin Nephelometric Units; $\mathrm{CMS}=$ cubic meters per second. 36

Figure 8. Schematic diagram depicting clockwise hysteresis using equations 1 and 2. TURL =Turbidity on the rising limb of the hydrograph, TU FL = Turbidity on the falling limb of the hydrograph $\mathrm{Qmin}=$ the discharge prior to the rise in the hydrograph 
preceding the event, Qmid =the discharge at the midpoint between , Qmin= prior to the beginning of the rise in the hydrograph, Qmax=the peak discharge during the event .. 36

Figure 9. Boxplot Comparison of Mean Daily Log Turbidity at Carter Bridge and Oregon City for Study Period ( $n=41$ ). 45

Figure 10. Boxplots showing log transformed mean daily turbidity measured at Carter Bridge and Oregon City during the Wet and Dry Season in water years 2006-2012 _.. 46

Figure 11. Intrasite comparison of Turbidity in Wet and Dry Seasons from 2006-2012 at Carter Bridge and Oregon City.

Figure 12. Boxplot of Calculated HI Values from Clackamas River at Carter Bridge and Clackamas at Oregon City $(n=41)$. 50

Figure 13. Scatter plots of linear fit of Log $\Delta T$ b as a function of Log $\Delta Q$ at Clackamas at Carter Bridge and Oregon City, Log $\Delta T$ urb=Natural $\log (\operatorname{Ln})$ of change in turbidity from initial increase to peak value during storm event, $\Delta Q=$ Natural Log (Ln) of change in discharge from initial increase to peak value during storm event, " $D$ " denotes dry season storm event 54

Figure 14. a-Diagnostic plots of Carter Bridge Wet Season model, b-Diagnostic plots of Carter Bridge Dry Season model.

Figure 15. Diagnostic plots of Oregon City Wet Season model, b-Diagnostic plots of Oregon City Dry Season model

Figure 16. a-Diagnostic plots of Carter Bridge all Storms model, b-Diagnostic plots of Oregon City all Storms model 60

Figure 17. Boxplots of (a) minimum, (b) peak, and (c) change in turbidity during storm events 63 


\section{Introduction}

Turbidity is a measure of the collective optical properties of a water sample that cause light to be scattered and absorbed rather than transmitted in straight lines. The higher the concentration of suspended particles, the higher the scattering and absorbance of light, and thus, the higher the turbidity value of the water sample. Primary contributors to turbidity include clay, silt, finely divided organic and inorganic matter, soluble colored organic compounds, plankton, and microscopic organisms (American Public Health Association and others, 1998). Turbidity is caused by sediment erosion, sediment resuspension and other particulate matter affecting the clarity of a water sample. Basin geology and soil composition, land-use and soil exposure, slope of a

river channel, geomorphic structure of the channel, precipitation and runoff, origin of the water including point and nonpoint sources are all components that affect the turbidity observed in rivers and streams. A conceptual model of the environmental influences that affect turbidity are represented in Figure 1. 


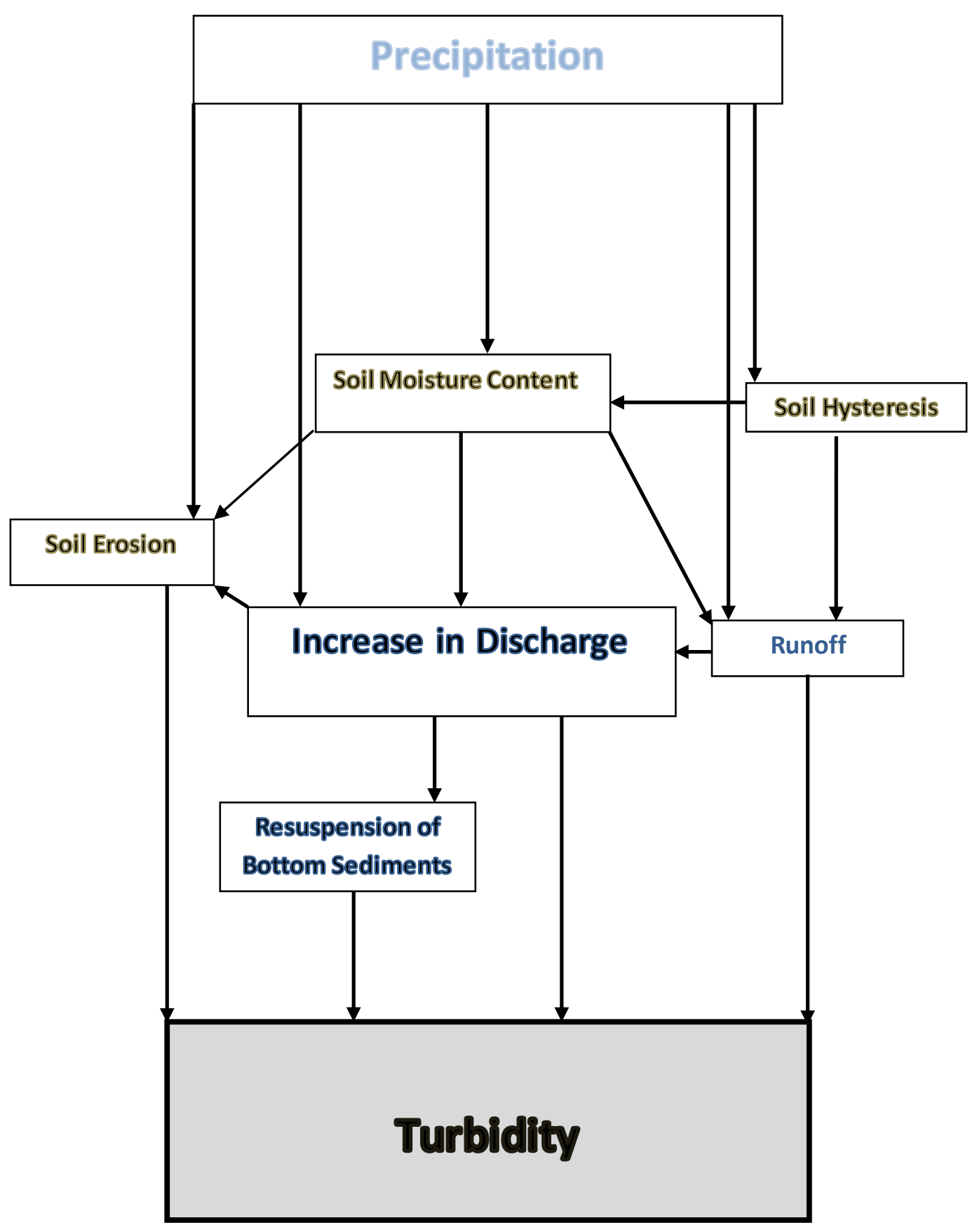

Figure 1. Conceptual model of elements that contribute to increased turbidity during storm events 
Turbidity measured in river waters during storm events exhibits a close positive relationship with suspended sediment concentration (SSC). Many studies have used turbidity measurements as a surrogate to calculate suspended sediment loads in rivers and streams (Wass et al., 1997, Uhrich et al., 2003, Chanson and Takeuchi, 2008, Uhrich and Kolasinac, 2014). This process involves measuring turbidity while simultaneously collecting water samples that are then analyzed for SSC. After the collection of sufficient samples, linear regression models are often used to calculate sediment loads (Bragg, 2007). Particle size, shape and composition can all be expected to influence light attenuation and turbidity, so any attempt to use turbidity measurements as a surrogate for direct determinations of SSC should take careful account of such factors (Gippel, 1989).

Increases in turbidity readings regularly occur during storm events when rainfall and storm runoff mobilize particles from the riparian zone, upstream locations in the watershed and the overall stream network within a catchment (Chen and Chang 2014).

Water from storm events and related runoff can increase river discharge and flow velocity. Increases in discharge are associated with increased shear velocities and turbulence and therefore an increased capacity to erode and transport sediment. Soil erosion and subsequent sediment transport into a waterway involves detachment, entrainment and eventual transport of particles via the stream network. The sources of sediment and particulate matter contributing to elevated turbidity readings can have an impact on the water quality of rivers, because various types of chemical compounds can 
be adsorbed on to the surface of sediment particles. Sediment, solids and other particulate matter can act as a substrate for transport of pollutants such as heavy metals (Horowitz, 1991), nutrients such as total phosphorus, bacteria (E. Coli), (Anderson and Rounds, 2003), nutrients (McKee and others, 2000), hydrocarbons and pesticides (Larson, 1997, Settle and Ashantha, 2007). Sediment and sediment-associated constituents are leading pollutants impacting waterbodies and undermining their values and functions for habitat, water supply, recreation, energy production, navigation and other functions (Fletcher and Deletic, 2007). Estimating the mass of pollutants (e.g. nutrients, heavy metals and sediment) is a prerequisite to the effective management of water quality in waterways (Fletcher and Deletic, 2007).

A number of studies have shown that a majority of annual sediment transport can occur during high flow storm events (Richards and Holloway, 1987; Longabucco and Rafferty, 1998; Davies-Colley and Smith, 2001; O'Donnell and Effler, 2006) (see Table 1). The dominant control on suspended sediment concentration is the supply of material to the river. The existence of a relationship between concentration and discharge is a reflection of the fact that sediment supply increases during periods of precipitation and storm runoff (Berrie, 1993). These periods are generally characterized by high discharges. These periods of high discharge will reflect not only land-use, soil and the underlying rock mineralogy, but also the antecedent soil moisture conditions as well as the spatial intensity and duration of rainfall (House and Warwick, 1998). 
Antecedent precipitation is precipitation falling before, but influencing the runoff yields of a given rainfall event. An antecedent precipitation index (API) is often used for the estimation of runoff yields from rainfall events on those watersheds whose auxiliary data are limited, or are not available (Ali et al., 2010). The importance of antecedent rainfall during intervals prior to the start of a rainstorm, in controlling the infiltration capacity of the soil profile and the initiation of runoff has been recognized for years (Istok and Boersma, 1986). The antecedent soil water content affects the infiltration rate. Wet soil has a lower infiltration rate than a dry soil. Precipitation falling on a wet soil will result in a higher runoff rate than the same amount of precipitation falling on a dryer soil.

Hysteresis in relation to soil moisture content is due to the fact that during soil wetting; the small pores fill first, while during drainage and drying the large pores empty first. Soil water hysteresis has a different relationship between soil water and soil suction during wetting and drying and will vary depending on the wetting and drying history of the soil (Ward and Trimble, 2004). As the pore size fills with water, the infiltration capacity of the soil profile decreases. Any additional rainfall occurring after soil saturation immediately becomes, runoff even if the rainfall intensity is very small (Istok and Boesrma, 1986). Hysteresis patterns in the relationship of discharge to suspended concentration have been investigated in efforts to understand the factors leading to the discharge-sediment transport patterns (Seeger et al., 2004). 
According to Nistor and Church (2005), the most common pattern is the clockwise hysteresis that indicates depletion of available sediment before the stream flow peak occurs. Counterclockwise hysteresis indicates delayed sediment travel time resulting from the downstream distance of the mea suring station from the sediment source (Williams, 1989). According to Asselman (1999), suspended sediment originating from the stream channel typically causes larger turbidity values during the rising limb of a stream flow peak (clockwise hysteresis), and sediment originating from more distant basin sources often causes larger turbidity values during the falling limb (counterclockwise hysteresis) of the storm hydrograph. The amount of particulate matter entrained in runoff is a chief determinant in turbidity to rivers during storm events.

Understanding the dynamics that lead to increased turbidity events can be helpful to researchers, regulatory agencies and water resource managers in maintaining high water quality in rivers such as the Clackamas River. 
Table 1. Representative studies investigating turbidity dynamics, hysteresis and suspended sediment during storm events

\begin{tabular}{|c|c|c|c|c|}
\hline Authors & $\begin{array}{l}\text { Study area } \\
\text { (size)/Land Use }\end{array}$ & Data Used & Methods & Findings \\
\hline $\begin{array}{l}\text { J.D. ISTOK } \\
\text { and L. } \\
\text { BOERSMA }\end{array}$ & $\begin{array}{l}\text { 5-watersheds from } \\
0.46-285 \text { hectares } \\
\text { Slopes ranging from } \\
4-15 \% \text { and } \\
\text { moderately deep, } \\
\text { well drained } \\
\text { deposits of silty } \\
\text { material overlying a } \\
\text { paleosol or } \\
\text { weathered } \\
\text { tuffaceous } \\
\text { sandstone. No } \\
\text { specific land use } \\
\text { information } \\
\text { provided, but based } \\
\text { on location in an } \\
\text { experimental } \\
\text { watershed in Polk } \\
\text { County, Oregon it is } \\
\text { likely a mostly } \\
\text { forested area. }\end{array}$ & $\begin{array}{l}\text { Various rainfall } \\
\text { parameters to } \\
\text { characterize } \\
\text { rainfall intensity } \\
\text { and rainfall } \\
\text { magnitude }\end{array}$ & $\begin{array}{l}\text { Stepwise discriminant } \\
\text { analysis to determine } \\
\text { the values and } \\
\text { combinations of rainfall- } \\
\text { event characteristics } \\
\text { that were significant in } \\
\text { predicting the } \\
\text { occurrence and amount } \\
\text { of rainfall. }\end{array}$ & $\begin{array}{l}\text { Antecedent } \\
\text { precipitation } \\
\text { falling during } \\
\text { the } 12-120 \\
\text { hours } \\
\text { preceding the } \\
\text { event was } \\
\text { most } \\
\text { important } \\
\text { variable in } \\
\text { determining } \\
\text { runoff. Mostly } \\
\text { clockwise } \\
\text { hysteresis for } \\
\text { particulate } \\
\text { nutrients ( } \mathrm{N} \\
\text { and } \mathrm{P} \text { ) }\end{array}$ \\
\hline $\begin{array}{l}\text { Y. } \\
\text { Tramblay1, } \\
\text { R. } \\
\text { Bouaicha2, }\end{array}$ & $\begin{array}{l}655 \mathrm{~km}^{2} \text { - Forested } \\
\text { land cover upstream } \\
\text { and cultivated plans } \\
\text { in the lower portions } \\
\text { of the basin. No } \\
\text { cities or urban areas }\end{array}$ & $\begin{array}{l}\text { Estimators } \\
\text { include an } \\
\text { antecedent } \\
\text { discharge index, } \\
\text { an antecedent } \\
\text { precipitation } \\
\text { index and } \\
\text { continuous daily } \\
\text { soil moisture } \\
\text { accounting } \\
\text { model (SMA) to } \\
\text { develop rainfall- } \\
\text { runoff models to } \\
\text { manage water } \\
\text { storage and } \\
\text { flooding }\end{array}$ & $\begin{array}{l}\text { Modeled } 16 \text { flood } \\
\text { events occurring over a } \\
\text { 24-year period. Rainfall, } \\
\text { discharge and satellite } \\
\text { remote sensing for soil } \\
\text { moisture using. }\end{array}$ & $\begin{array}{l}\text { The best } \\
\text { results were } \\
\text { obtained with } \\
\text { daily soil } \\
\text { moisture } \\
\text { accounting } \\
\text { (SMA) model. } \\
\text { Remote } \\
\text { sensing data } \\
\text { were deemed } \\
\text { potentially } \\
\text { useful to } \\
\text { estimate the } \\
\text { soil moisture } \\
\text { conditions in }\end{array}$ \\
\hline
\end{tabular}




\begin{tabular}{|c|c|c|c|c|}
\hline $\begin{array}{l}\text { J. Philip } \\
\text { O'KANE }\end{array}$ & $\begin{array}{l}\text { Conceptual model of } \\
\text { hysteresis in } \\
\text { hydrology. Discusses } \\
\text { rate-dependent and } \\
\text { rate-independent } \\
\text { systems in the } \\
\text { unsaturated zone of } \\
\text { the hydrological } \\
\text { cycle }\end{array}$ & $\begin{array}{l}\text { Introduces the } \\
\text { concept of rate- } \\
\text { independence in } \\
\text { a hydrological } \\
\text { context. Shows } \\
\text { how to insert } \\
\text { rate- } \\
\text { independent } \\
\text { hysteresis in } \\
\text { conceptual } \\
\text { hydrological } \\
\text { models }\end{array}$ & $\begin{array}{l}\text { Details and derives } \\
\text { equations describing } \\
\text { hysteresis in soil physics } \\
\text { and hydrology }\end{array}$ & $\begin{array}{l}\text { Resource } \\
\text { about for } \\
\text { hysteretic } \\
\text { theory. Paper } \\
\text { explained } \\
\text { rate- } \\
\text { independent } \\
\text { hysteresis that } \\
\text { contributes to } \\
\text { the goal of } \\
\text { predicting } \\
\text { hydrologic } \\
\text { response }\end{array}$ \\
\hline $\begin{array}{l}\text { WILLIAM A. } \\
\text { HOUSE**M } \\
\text { and } \\
\text { MELANIES. } \\
\text { WARWICK }\end{array}$ & $\begin{array}{l}\text { One large catchment } \\
\text { and two nested sub } \\
\text { catchments. One site } \\
54 \text { km downstream. } \\
\text { Mixed land use of } \\
\text { Agricultural, } \\
\text { livestock (cattle and } \\
\text { sheep) and urban } \\
\text { areas }\end{array}$ & $\begin{array}{l}\text { Attempted to } \\
\text { quantify and } \\
\text { model hysteresis } \\
\text { effect using } \\
\text { detailed } \\
\text { chemical and } \\
\text { river discharge } \\
\text { data collected at } \\
2 \text { hour intervals. } \\
\text { Diffuse inputs } \\
\text { related to } \\
\text { discharge }\end{array}$ & $\begin{array}{l}\text { Comparing nutrient } \\
\text { samples collected } \\
\text { during baseflow and } \\
\text { stormflow conditions. } \\
\text { An empirical mass- } \\
\text { balance model on water } \\
\text { in soil to determine } \\
\text { magnitude and } \\
\text { direction of } \\
\text { concentration/discharge } \\
\text { hysteresis }\end{array}$ & $\begin{array}{l}\text { Results } \\
\text { illustrate } \\
\text { hysteresis } \\
\text { effects for all } \\
\text { of the } \\
\text { determinants } \\
\text { and diffuse } \\
\text { inputs with } \\
\text { the majority of } \\
\text { events } \\
\text { demonstrating } \\
\text { clockwise' } \\
\text { hysteresis }\end{array}$ \\
\hline Authors & $\begin{array}{l}\text { Study area } \\
\text { (size)/Land Use }\end{array}$ & Data Used & Methods & Findings \\
\hline $\begin{array}{l}\text { Lester } \\
\text { McKee, } \\
\text { Bradley } \\
\text { Eyre and } \\
\text { Shahadat } \\
\text { Hossain }\end{array}$ & $\begin{array}{l}99,000 \mathrm{~km}^{2}- \\
4 \text { sub basins of } \\
\text { mixed land use } \\
\text { primarily forested } \\
\text { and agricultural with } \\
\text { urban areas less than } \\
10 \%\end{array}$ & $\begin{array}{l}\text { Compare and } \\
\text { contrast intra } \\
\text { and interannual } \\
\text { variations in } \\
\text { nutrient loads } \\
\text { during storm } \\
\text { events } \\
\text { Hysteresis } \\
\text { explained by } \\
\text { flushing of } \\
\text { antecedent } \\
\text { material and } \\
\text { exhaustion of } \\
\text { material during } \\
\text { single or } \\
\text { consecutive } \\
\text { storms }\end{array}$ & $\begin{array}{l}\text { Water samples } \\
\text { collected for nutrient } \\
\text { analysis nitrogen }(\mathrm{N}) \\
\text { and phosphorus }(\mathrm{P}) \text { on } \\
\text { the rising and falling } \\
\text { limb of storm } \\
\text { hydrograph }\end{array}$ & $\begin{array}{l}\text { Particulate } \\
\text { nitrogen and } \\
\text { phosphorus } \\
\text { showed a } \\
\text { clockwise } \\
\text { hysteresis loop } \\
\text { during all } \\
\text { flood events. } \\
\text { Majority of } \\
\text { nutrients } \\
\text { transported } \\
\text { during storms }\end{array}$ \\
\hline
\end{tabular}




\begin{tabular}{|c|c|c|c|c|}
\hline $\begin{array}{l}\text { Evans, C., } \\
\text { and T.D. } \\
\text { Davies. } \\
1998\end{array}$ & $\begin{array}{l}\text { Data collected in } \\
\text { Adirondacks New } \\
\text { York and the } \\
\text { Northern } \\
\text { Appalachian Plateau } \\
\text { in Pennsylvania }\end{array}$ & $\begin{array}{l}\text { Models of runoff } \\
\text { generation are } \\
\text { used to explain } \\
\text { this hysteresis } \\
\text { effect and to } \\
\text { illustrate how } \\
\text { different } \\
\text { component } \\
\text { concentrations } \\
\text { produced } \\
\text { different } \\
\text { hysteresis forms. } \\
\text { Only single peak } \\
\text { events and a } \\
\text { minimum of two } \\
\text { samples } \\
\text { collected on } \\
\text { each limb of } \\
\text { hydrograph }\end{array}$ & $\begin{array}{l}\text { Model concentration- } \\
\text { discharge hysteresis by } \\
\text { modeling a 3- } \\
\text { component approach. } \\
\text { Pre-event, event water } \\
\text { sources-and water from } \\
\text { the soil-zone is a third } \\
\text { component }\end{array}$ & $\begin{array}{l}\text { Concentration- } \\
\text { Discharge } \\
\text { relationship } \\
\text { between } \\
\text { groundwater, } \\
\text { solid water } \\
\text { and surface } \\
\text { water }\end{array}$ \\
\hline $\begin{array}{l}\text { Jack Lewis } \\
\text { and Rand } \\
\text { Eads }\end{array}$ & $\begin{array}{l}\text { 5-storms in a } 946 \\
\text { acre rain dominated } \\
\text { watershed with } \\
\text { mostly fine-grain } \\
\text { sediment. Fewer } \\
\text { than } 10 \text { storm events } \\
\text { in a } 20,000 \text { acre } \\
\text { basin with } \\
\text { predominantly sand } \\
\text { sized particles }\end{array}$ & $\begin{array}{l}\text { Provide } \\
\text { information on } \\
\text { use, benefits and } \\
\text { cautions of } \\
\text { continuous } \\
\text { turbidity } \\
\text { measurements } \\
\text { comparing and } \\
\text { contrasting two } \\
\text { basins with } \\
\text { different } \\
\text { sediment types }\end{array}$ & $\begin{array}{l}\text { Linear regression to fit } \\
\text { suspended sediment } \\
\text { concentration to } \\
\text { turbidity at } 10 \text {-minute } \\
\text { intervals }\end{array}$ & $\begin{array}{l}\text { Turbidity is } \\
\text { probably more } \\
\text { useful than } \\
\text { water } \\
\text { discharge as a } \\
\text { long-term } \\
\text { predictor of } \\
\text { SSC }\end{array}$ \\
\hline $\begin{array}{l}\text { D.M. Lawler } \\
\text { a, }{ }^{*}, \text { G.E. } \\
\text { Petts a, } \\
\text { I.D.L. Foster } \\
\text { b, S. Harper }\end{array}$ & $\begin{array}{l}\text { Upper Tames River } \\
\text { in West Midlands } \\
\text { UK. Urbanized basin } \\
\text { with numerous } \\
\text { industrial and } \\
\text { domestic water } \\
\text { supply systems. }\end{array}$ & $\begin{array}{l}\text { Investigating an } \\
\text { urban } \\
\text { headwater } \\
\text { stream during a } \\
\text { series of spring } \\
\text { storms by } \\
\text { evaluating } \\
\text { storm-event } \\
\text { turbidity } \\
\text { dynamics. A } \\
\text { hysteretic index } \\
\text { (HI) on turbidity. } \\
\text { Turbidity during } \\
\text { the initial, mid } \\
\text { and peak flow of } \\
\text { an event was } \\
\text { used to } \\
\text { investigate } \\
\text { turbidity during }\end{array}$ & $\begin{array}{l}\text { 15 spring storms } \\
\text { analyzed to investigate } \\
\text { ammonia peaks, biofilm } \\
\text { formation, bed } \\
\text { sediment stores using } \\
\text { HI and assessing } \\
\text { turbidity on rising and } \\
\text { falling limb of the storm } \\
\text { hydrograph }\end{array}$ & $\begin{array}{l}\text { Found more } \\
\text { counter clock- } \\
\text { wise hysteresis } \\
\text { in urban } \\
\text { catchments. } \\
\text { This contrasts } \\
\text { with clockwise } \\
\text { hysteresis } \\
\text { mostly } \\
\text { observed in } \\
\text { more rural } \\
\text { landscapes. }\end{array}$ \\
\hline
\end{tabular}




\begin{tabular}{|c|c|c|c|c|}
\hline & & storm events. & & \\
\hline Authors & $\begin{array}{l}\text { Study area } \\
\text { (size)/Land Use }\end{array}$ & Data Used & Methods & Findings \\
\hline $\begin{array}{l}\text { Paul V } \\
\text { Bolstad and } \\
\text { Wayne T } \\
\text { Swank2 }\end{array}$ & $\begin{array}{l}8.7 \text { stream } \\
\text { kilometers covering } \\
\text { 5-monitoring } \\
\text { stations of varying } \\
\text { land use between } \\
\text { each station. } \\
\text { Upstream mainly } \\
\text { deciduous forests. } \\
\text { Other 4-stations had } \\
\text { mix of pastures, } \\
\text { home sites, and } \\
\text { farmland and low } \\
\text { density suburban } \\
\text { mix. }\end{array}$ & $\begin{array}{l}\text { Land use } \\
\text { characterizations } \\
\text { by using 50, } 100 \\
\text { and } 300 \text { meter } \\
\text { buffers. } \\
\text { Compared } \\
\text { baseflow and } \\
\text { stormflow } \\
\text { concentrations } \\
\text { of various water } \\
\text { quality and } \\
\text { chemical } \\
\text { constituents to } \\
\text { compare } \\
\text { downstream } \\
\text { changes in water } \\
\text { quality during } \\
\text { storms }\end{array}$ & $\begin{array}{l}\text { Nutrient, metals, field } \\
\text { parameters (water } \\
\text { temperature, dissolved } \\
\text { oxygen, turbidity and } \\
\text { conductivity), bacteria } \\
\text { during baseflow and } \\
\text { storm conditions were } \\
\text { compared to assess } \\
\text { downstream changes in } \\
\text { water quality }\end{array}$ & $\begin{array}{l}\text { Cumulative } \\
\text { impacts of } \\
\text { other land } \\
\text { uses appear to } \\
\text { greatly } \\
\text { increase } \\
\text { turbidity, } \\
\text { bacteria and } \\
\text { inorganic } \\
\text { solutes during } \\
\text { stormflow. } \\
\text { Likely due to } \\
\text { overland flow } \\
\text { and transport } \\
\text { of materials } \\
\text { directly to the } \\
\text { stream }\end{array}$ \\
\hline $\begin{array}{l}\text { Milan } \\
\text { Onderka \& } \\
\text { Andreas } \\
\text { Krein }\end{array}$ & $\begin{array}{l}2.7 \mathrm{~km}^{2} \text { in a humid } \\
\text { temperate } \\
\text { catchment in } \\
\text { Luxembourg. 98\% } \\
\text { mixed forest land } \\
\text { cover and a network } \\
\text { of unsealed forest } \\
\text { roads, a primary } \\
\text { source of sediment } \\
\text { during runoff. }\end{array}$ & $\begin{array}{l}\text { Incorporated } \\
\text { antecedent } \\
\text { hydro } \\
\text { meteorological } \\
\text { data into SSC } \\
\text { prediction } \\
\text { models in a } \\
\text { headwater } \\
\text { catchment in } \\
\text { Huewelerbach } \\
\text { Luxembourg. } \\
\text { Baseflow, peak } \\
\text { flow antecedent } \\
\text { precipitation } \\
\text { indices (API), } \\
\text { total }\end{array}$ & $\begin{array}{l}\text { Comparison results } \\
\text { from } 21 \text {-storm events } \\
\text { using of a modular data } \\
\text { driven model tree to } \\
\text { results from } \\
\text { conventional power-law } \\
\text { rating curves models. }\end{array}$ & $\begin{array}{l}\text { Conclusions } \\
\text { highlight the } \\
\text { dominant } \\
\text { antecedent } \\
\text { hydro- } \\
\text { meteorological } \\
\text { conditions } \\
\text { acting as the } \\
\text { major controls } \\
\text { on the } \\
\text { magnitude of } \\
\text { sSC during } \\
\text { storm events. } \\
\text { Antecedent } \\
\text { runoff volume } \\
\text { explained }\end{array}$ \\
\hline
\end{tabular}




\begin{tabular}{|c|c|c|c|c|}
\hline & & $\begin{array}{l}\text { precipitation and } \\
\text { maximum } \\
\text { suspended } \\
\text { sediment } \\
\text { concentration } \\
\text { were used. A } \\
\text { total of } 21 \text { storm } \\
\text { events were } \\
\text { analyzed and } \\
\text { API's of } 1 \text {, } \\
5,7 \text {,and } 14 \text { days } \\
\text { were used in } \\
\text { models }\end{array}$ & & $\begin{array}{l}\text { depletion of } \\
\text { sediments }\end{array}$ \\
\hline Authors & $\begin{array}{l}\text { Study area } \\
\text { (size)/Land Use }\end{array}$ & Data Used & Methods & Findings \\
\hline $\begin{array}{l}\text { M. } \\
\text { Seegera, }{ }^{*}, \\
\text { M.-P. } \\
\text { Erreab, S. } \\
\text { Begueriab, }\end{array}$ & $\begin{array}{l}2.84 \mathrm{~km}^{2} \text { steep } \\
\text { sloped mountainous } \\
\text { area with bedrock of } \\
\text { alternating } \\
\text { sandstone and marl } \\
\text { layers which is highly } \\
\text { erodible and low } \\
\text { infiltration capacity. } \\
\text { Former land use } \\
\text { included cereal crops } \\
\text { that were } \\
\text { abandoned in the } \\
\text { middle } 20^{\text {th }} \text { century }\end{array}$ & $\begin{array}{l}\text { To understand } \\
\text { factors leading } \\
\text { to the Q-sed. } \\
\text { Transport } \\
\text { patterns. } \\
\text { Identification of } \\
\text { different } \\
\text { hysteresis loops } \\
\text { and their } \\
\text { generation Total, } \\
\text { average and } \\
\text { maximum } \\
\text { precipitation } \\
\text { were the rainfall } \\
\text { variables. } \\
\text { antecedent } \\
\text { precipitation } \\
\text { indices (API),of } \\
6 \text {-hours (AP6) } \\
\text { and API's of } \\
1,3,7,15 \text {,and } 21 \\
\text { days were used } \\
\text { to ,assess soil } \\
\text { moisture } \\
\text { conditions prior } \\
\text { to rainfall events }\end{array}$ & $\begin{array}{l}\text { Water level and } \\
\text { suspended sediment } \\
\text { load (measured by } \\
\text { turbidity) and rainfall } \\
\text { collected every 5- } \\
\text { minutes and solar } \\
\text { radiation, air } \\
\text { temperature, wind } \\
\text { speed and conductivity } \\
\text { are measured and } \\
\text { logged every 15- } \\
\text { minutes. }\end{array}$ & $\begin{array}{l}\text { Hysteresis } \\
\text { loops were } \\
\text { dependent on: } \\
\text { Total } \\
\text { precipitation, } \\
\text { antecedent } \\
\text { precipitation } \\
\text { and soil } \\
\text { moisture. Soil } \\
\text { moisture was } \\
\text { significant } \\
\text { factor } \\
\text { differentiating } \\
\text { hysteretic } \\
\text { loops. Those } \\
\text { loops are } \\
\text { expressions of } \\
\text { different } \\
\text { runoff } \\
\text { generating } \\
\text { processes and } \\
\text { of changes in } \\
\text { contributing } \\
\text { areas }\end{array}$ \\
\hline $\begin{array}{l}\text { NANCY E. } \\
\text { DRIVER and } \\
\text { BRENT M. } \\
\text { TROUTMAN }\end{array}$ & $\begin{array}{l}\text { From a database } \\
\text { comprised of } 2,813 \\
\text { storms at } 173 \text { urban } \\
\text { sites in } 300 \\
\text { metropolitan areas } \\
\text { throughout the U.S. }\end{array}$ & $\begin{array}{l}\text { Liner regression } \\
\text { models were } \\
\text { developed for } \\
\text { the estimation } \\
\text { of storm-runoff } \\
\text { loads and } \\
\text { volumes from }\end{array}$ & $\begin{array}{l}\text { Regional regression } \\
\text { models were developed } \\
\text { to relate storm-runoff } \\
\text { loads and volumes to } \\
\text { physical, land-use and } \\
\text { climatic characteristics. }\end{array}$ & $\begin{array}{l}\text { Total storm } \\
\text { rainfall and } \\
\text { total } \\
\text { contributing } \\
\text { drainage area } \\
\text { most } \\
\text { significant }\end{array}$ \\
\hline
\end{tabular}




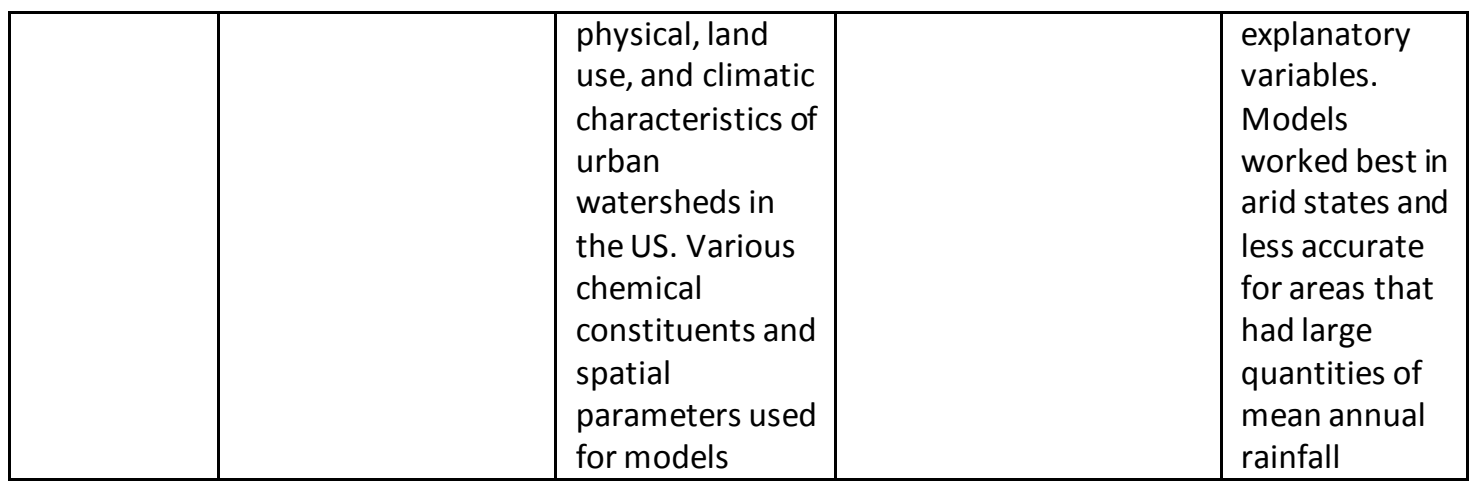

\subsection{Aims and Objectives}

The objective of this study is to use data collected at water-quality monitoring stations, discharge gauges and available precipitation data to identify the major hydro meteorological controls that determine the magnitude of turbidity measured in the Clackamas River during high-flow storm-runoff events. In-situ turbidity, acoustic and streamflow data can be used to compute a time series of suspended-sediment concentrations and loads at stream sites (Rasmussen et al., 2008). Continuous turbidity data provide a record of the changes in optical clarity of a waterbody over time and are a useful tool in efforts to study water-quality conditions, trends and other aspects concerning the dynamics and interactions within an aquatic ecosystem. Turbidity, river discharge and precipitation information will be used to understand the response of turbidity to different amounts of discharge and precipitation during high-flow storm runoff events in the Clackamas River Basin. 
Understanding mechanisms controlling the transport of solids from catchments is important for maintaining high water quality and the reduction of excessive soil erosion. Adequate knowledge of sediment transport phenomena has implications for river morphology, siltation of water reservoirs, transport of sediment-bound contaminants and soil erosion (Onderka et al., 2012). In naturally vegetated headwater catchments, suspended sediments are normally transported during flood events. The use of continuous turbidity measurements can be a useful tool to assist in efforts to investigate particle transport and sediment concentrations in rivers, lakes and other water bodies.

The U.S. Geological Survey (USGS) in cooperation with the Clackamas River Water Providers (CRWP) operates a network of continuous water-quality monitors in the Clackamas Basin. These monitors measure properties of water including, water temperature, specific conductance, $\mathrm{pH}$, dissolved oxygen, and turbidity. Continuous real-time data provide high-resolution information for water-quality parameters and a record of the physical changes in a waterbody over time. Information about instream processes at different times of day such as diurnal fluctuations in $\mathrm{pH}$ and dissolved oxygen related to algal growth, seasonal changes under various flow conditions and before/after catastrophic events such as landslides or floods. Physical properties of water, such as suspended sediments, can have substantial effects on water quality and aquatic habitat. Changes in these constituents may cause changes in other water-quality characteristics (Esralew et al., 2011). 
The two sites selected for this study represent two different flow regimes in the Clackamas River drainage basin. Carter Bridge, the upper reach is located downstream of a primarily forested landscape. , and Oregon City, the lower reach, is located downstream of a mixed land-use environment. These two sites were selected for two reasons:

1. Both stations as part of the USGS gauging stations have water-quality monitors, which provide discharge and water-quality data.

2. The upper reach (Carter Bridge) and the lower reach (Oregon City) are of particular interest because they are nested. Consequently, any differences in hydrologic response to storm events can be attributed to contributions from downstream areas of the lower reach that are not included upstream of the monitoring stations on the upper reach (Sheeder et al., 2002).

In order to understand the differences in turbidity measured at these two stations, we must consider the differences in their landscape characteristics, which have a considerable amount of influence on composition of particles entering the river and being measured by the turbidity sensor; especially during storm events. 


\subsection{Research Questions -}

1. Are there any differences in the mean concentration of turbidity measured during high-flow storm events between less developed upstream (the Carter Bridge) and more developed downstream (Oregon City) water-quality monitoring stations on the Clackamas River?

2. Are there any differences in the hysteresis index $(\mathrm{HI})$ of turbidity between the two stations? What are the dominant hysteresis regimes in both stations by season?

3. Of the following parameters: antecedent precipitation index(API), total precipitation and discharge; which one or combinations of these parameters are the major controls that determine the change in turbidity measured during storm events in the Clackamas River? 


\subsection{Hypotheses}

\section{Hypothesis \#1-}

There are statistically significant differences in turbidity measurements during storm events between the Carter Bridge and the Oregon City water-quality monitoring stations (Figure 2).

I hypothesize that turbidity measured at each site during storm events between the two stations will be different. The Clackamas River at Carter Bridge site is the furthest upstream station and located in the predominantly forested upstream reach of the basin. The Clackamas River at Oregon City station is located in the lower reach of the basin (located at river kilometer 2.6), which is about 3\% urban in comparison to only $0.4 \%$ in the upper Clackamas Basin near the Carter Bridge site (USGS, StreamStats). This study will investigate the changing turbidity during storm events between a forested rural upland sub-watershed and a downstream urban sub-watershed.

\section{Hypothesis \#2}

Seasonal hysteresis patterns, as measured by hysteresis index, are expected to be different between the two sites in wet and dry seasons. I hypothesize that hysteresis patterns will show more complex pattern in the downstream site than in the upstream site. Additionally, hysteresis patterns are expected to be less pronounced in the dry season than the wet season. 


\section{Hypothesis \#3-}

Are stream discharge $(Q)$, total precipitation $\left(P_{\text {total }}\right)$ amount, antecedent precipitation indices (API) of $3,5,7,14$ and 30 days, or combination of these variables the major control that determines the change of turbidity during storms measured at the two selected Clackamas River sites?

I hypothesize that by using discharge, $\mathrm{API}$, and $\mathrm{P}_{\text {total }}$ as independent variables in multiple linear regression analysis, it is possible to determine which variable (or combination of variables) correlates best with the change of turbidity measured at the two Clackamas River sites during storm events. 


\section{Study Area}

\section{Study Area}

Located in the Cascade Range of western Oregon, the Clackamas Basin covers approximately $2,440 \mathrm{~km}^{2}$ of forested, rural and urban land in northwestern Oregon (Figure 2). The Clackamas River originates on the western slopes of the Cascade Mountains between Mount Hood and Mount Jefferson and descends for approximately 2,190-meters on a northwesterly course winding through prominent basalt outcrops and cliffs (Carpenter, 2003). The soils in the northern part of the basin are mainly silty and many of them have a brittle hardpan in the subsoil. The soils in the southwestern portion of the basin range widely in texture and drainage, but are mostly composed of silt loam and silty clay loam (Gerig, 1985). The upper portion of the Clackamas Basin's geology and soils are primarily influenced by processes in the Cascade Mountains. In the upper portion of the basin towards the east soils are mainly well drained gravelly loam to very cobbly loam and have high content of volcanic ash, slopes are steep to very steep (Gerig, 1985). The mountains are composed of recently active volcanoes along the Cascade Crest to the east (i.e., The High Cascades), and older, inactive mountains to the west (i.e., the Western Cascades). The upper portion of the basin contains about equal portions of both of these geologic areas. The Western Cascades are steep and welleroded with shallow subsurface confining layers, while the High Cascades form a broad volcanic platform underlain by highly porous and permeable volcanic layers (Graves and 
Chang, 2007). The upper Clackamas Basin is mostly forested and contains virtually no development aside from its road network, hydropower facilities, and a few residences (Graves and Chang, 2007).

The upstream forested areas of the basin have been affected by afforestation and deforestation (Taylor, 1999). Timber harvests in the lower basin started in the early 1800s. The lack of good roads above the Estacada area (Figure 2) and easy access to trees in the lower basin tied most activities to lower basin forests until the $1940 \mathrm{~s}$ (Taylor, 1999). Between 1950 and 1994 timber harvests occurred on more than 29 percent of the upper Clackamas watershed (Taylor, 1999). Forestry operations are often associated with increased erosion. Land drainage operations, the construction of access roads and felling operations involving soil compaction and disturbance all increase erosion (Taylor, 1999). 


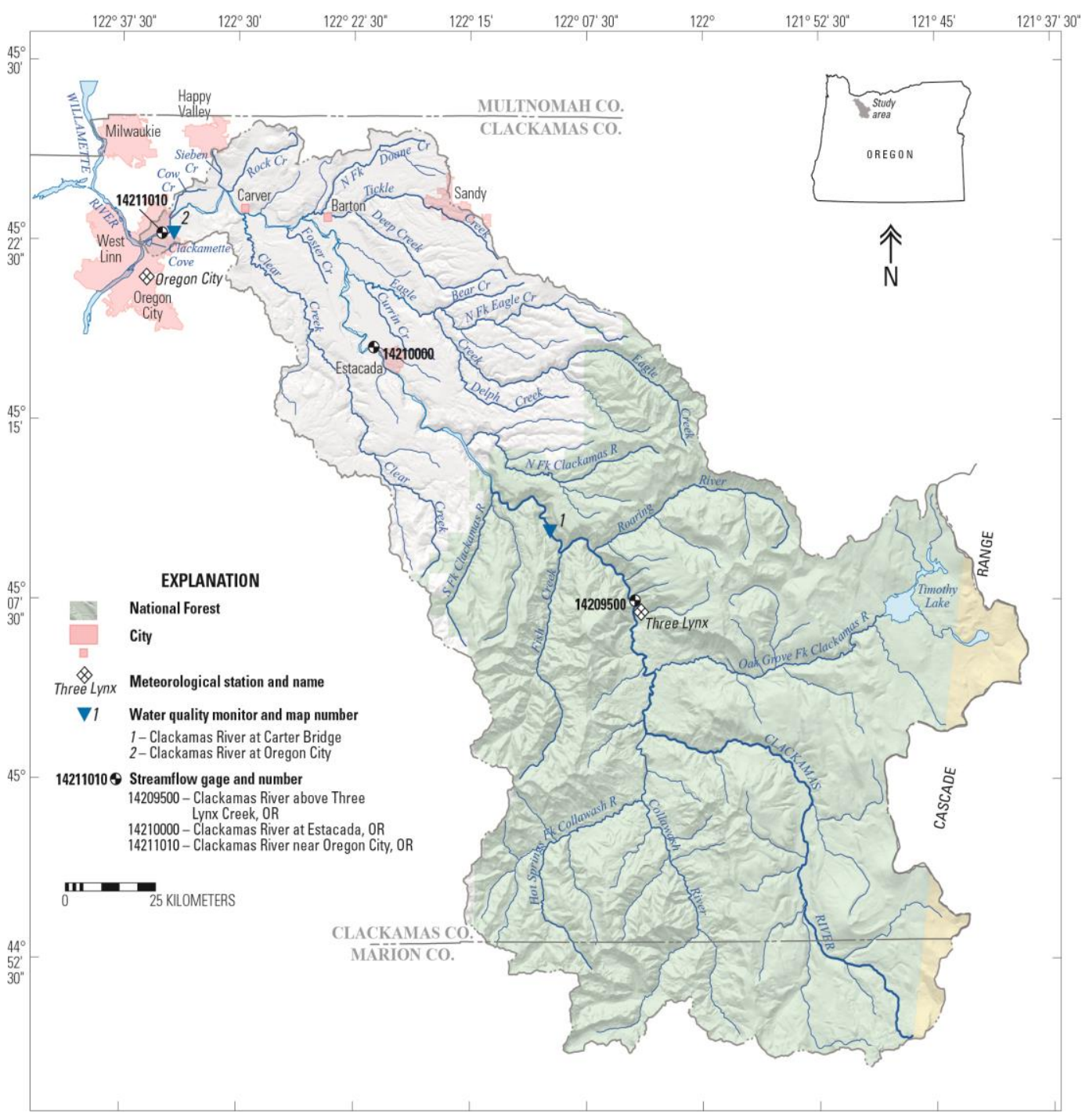

Figure 2. Map of Clackamas River Basin showing water-quality monitors, stream discharge gauging sites and precipitation stations

The Clackamas River flows for 133 kilometers from the upper-forested reaches where it meanders through a series of tributary inputs, riffle areas and side channels (Figure 2). The approximately 76-kilometer longitudinal distance of the Upper Clackamas River, from its headwaters to above of North Fork Reservoir, is included as 
part of the Federal Wild and Rivers System. Portland General Electric (PGE) operates three hydroelectric dams on the Clackamas River between river kilometers 75.3 and 35.9.

The Clackamas River from Carver (RK 12.9) to River Mill Dam near the Estacada gauging station (Figure 2) is a "recreational river area" under Oregon's Scenic Waterway Program (Taylor, 1999). The river also provides habitat for several migrating fish and other aquatic species. The Clackamas River supports many recreational activities, including fishing, rafting and kayaking, and it supplies drinking water for over 300,000 residents (Clackamas River Water Providers, 2017).

Downstream of Estacada, the Clackamas River widens into a lower-gradient, meandering system and is open to influences from agriculture and a growing urban population. The lower basin contains a predominantly alluvial valley, where the river flows through a broad floodplain of coarse material, much of which is mined for rock and gravel (Metro, 1997). Steep cliffs constrain the floodplain, and much of the Christmas tree and commercial tree plantations, agriculture, and rural residential areas are located on plateaus and terraces well above the floodplain. Other agricultural crops grown in the Clackamas Basin are red raspberries, strawberries, grass seed, hay along with some pasture and grazing (Gerig, 1985). Soil is susceptible to compaction if grazing is permitted when the soils are wet (Gerig, 1985). Compaction increases runoff and erosion during rain events. 
Human activities in the basin, including timber harvesting, construction of roads and urban developments, farming, gravel mining, and hydroelectric power generation also may affect water quality. The largest inputs of contaminants introduced by human development occur in the lower basin, particularly on the north side of the Clackamas River, where agriculture and urban land is concentrated. Water-quality problems, such as high levels of turbidity, also occasionally occur from soil erosion, particularly in the upper basin where topography and geologic instability, combined with abundant winter precipitation contribute to erosion during periods of heavy runoff (Carpenter, 2003). 


\section{Data and Methods}

\subsection{Data}

\subsubsection{Turbidity Data}

To obtain a minimum of 30 storm events for analysis, real-time continuous turbidity data measured in water years 2006-2012 on the Clackamas River at Carter Bridge and at the Clackamas River at Oregon City sites were used for this research. The location of the USGS water-quality monitoring (WQM) stations used for this study are listed below in Table 2 and shown in Figure 2. Mean, median and maximum daily values were computed from instantaneous data collected in 30-minute intervals by continuous water-quality monitors over the period of a day.

Turbidity measurements in the Clackamas River were obtained using a Yellow Springs Instrument (YSI) 6026 turbidity sensor attached to a YSI multi-parameter sonde. The YSI 6026 sensor is a self-cleaning turbidity sensor with a wiper (the wiper is necessary to minimize sensor fouling) designed for long-term, in-situ continuous turbidity monitoring. The instrument measures turbidity with an optical sensor. Light from the near-infrared light-emitting diode (LED) enters the water-sample and light rays scatter off of water particles. The light, scattered at 90 degrees, enters a detector fiber and is measured by a photodiode (Figure 2) (YSI Inc., 2009). 
Table 2. Latitude and Longitude coordinates of water quality (including turbidity), discharge monitoring stations and precipitation measuring stations

\begin{tabular}{|l|l|l|l|}
\hline $\begin{array}{l}\text { Name and USGS } \\
\text { Site Identification } \\
\text { number }\end{array}$ & $\begin{array}{l}\text { Data } \\
\text { Collected }\end{array}$ & Latitude & Longitude \\
\hline $\begin{array}{l}\text { Clackamas above } \\
\text { Three Lynx } \\
(14209500)\end{array}$ & Discharge & $45^{\circ} 07^{\prime} 30^{\prime \prime}$ & $122^{\circ} 04^{\prime} 20^{\prime \prime}$ \\
\hline $\begin{array}{l}\text { Clackamas at } \\
\text { Carter Bridge } \\
(14209710)\end{array}$ & Water-quality & $45^{\circ} 10^{\prime} 02^{\prime \prime}$ & $122^{\circ} 09^{\prime} 18^{\prime \prime}$ \\
\hline $\begin{array}{l}\text { Clackamas at } \\
\text { Oregon City } \\
\text { (14211010) }\end{array}$ & $\begin{array}{l}\text { Water-quality } \\
\text { and Discharge }\end{array}$ & $45^{\circ} 22^{\prime} 46^{\prime \prime}$ & $122^{\circ} 34^{\prime} 34^{\prime \prime}$ \\
\hline $\begin{array}{l}\text { Three Lynx } \\
358466-4\end{array}$ & Precipitation & $45^{\circ} 07^{\prime}$ & $122^{\circ} 04^{\prime}$ \\
\hline $\begin{array}{l}\text { Oregon City } \\
\text { 356334-2 }\end{array}$ & Precipitation & $45^{\circ} 21^{\prime}$ & $122^{\circ} 36^{\prime}$ \\
\hline
\end{tabular}

The sensor uses a LED with a wavelength of $840 \pm 60$ nanometers, and the detector is at an angle of $90 \pm 2.5$ degrees to the incident light beam. Turbidity measurements obtained with these specifications are measured in Formazin Nephelometric Units (FNU). Therefore, measurements of turbidity for this study will be reported in FNU. This method conforms to the International Standardization Organization (ISO) Method 7027 of turbidity measurement (International Organization for Standardization, 1999). The strengths of ISO Method 7027 include the use of a near-monochromatic light source that is stable, low absorbance interference with samples, in low stray light (Sadar, 1999). Turbidity data used for this study have been collected, checked and reviewed in 
accordance with established USGS protocols (Wagner et al., 2006). Water-quality data from 2006-2012 selected for this study were downloaded from the USGS Data Grapher webpage (http://or.water.usgs.gov/cgi-bin/grapher/graph_setup.pl). Summary and statistical information for turbidity data are listed in Appendix A.

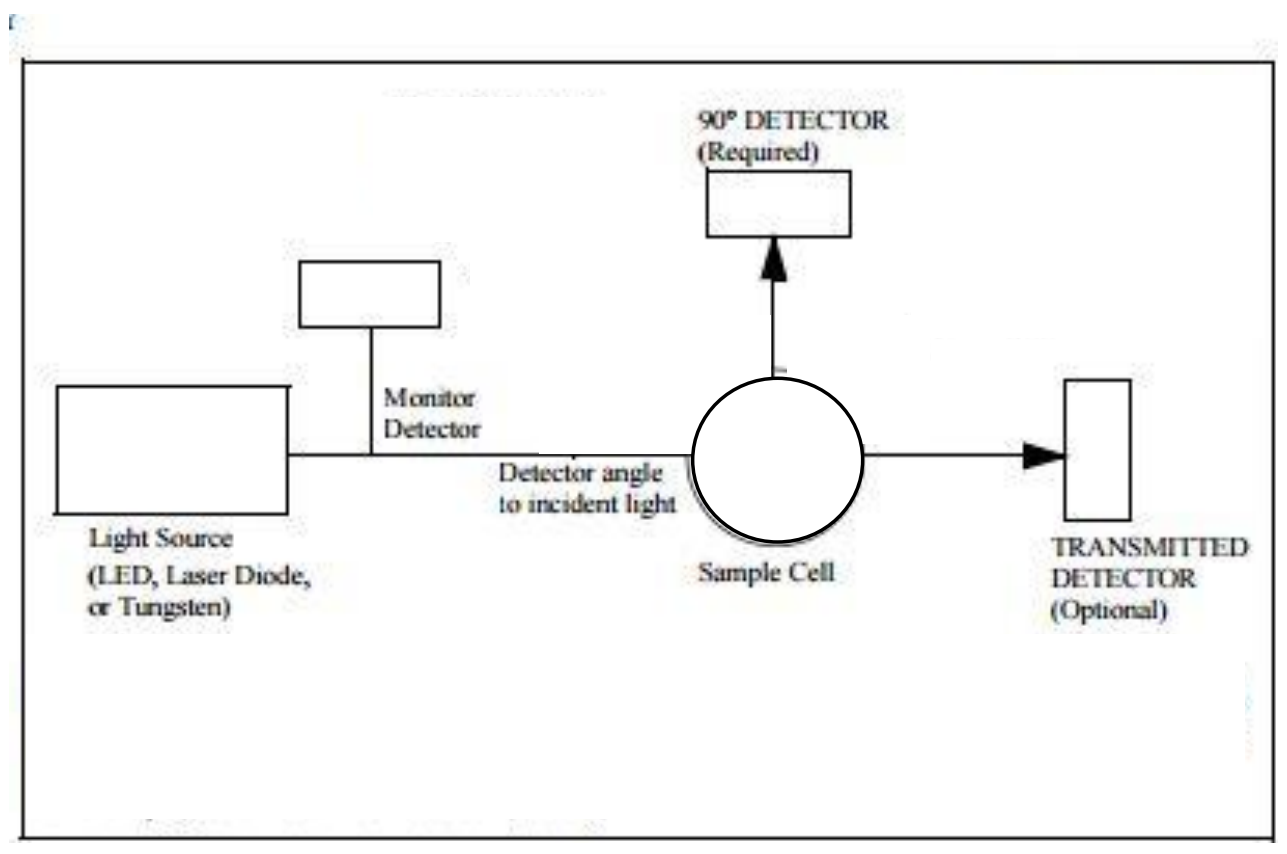

Figure 3. Schematic of how turbidity sensor operates

\subsubsection{Discharge Data}

Discharge monitoring stations in the Clackamas River above Three Lynx and Clackamas River at Oregon City were used for this study (Table 2 and Figure 2). Streamflow discharge at these stations are measured and logged continuously every 30 minutes. Mean daily values are calculated from the continuously logged readings. Streamflow discharge data are collected and reviewed in accordance with USGS protocols (Rantz et al., 1982). 
Data from Clackamas above Three Lynx were used as a surrogate for discharge at the Clackamas at Carter Bridge site, because Carter Bridge does not have a gauging station. The two locations have similar basin characteristics (see Table 3). The Three Lynx location provides suitable representation of discharge occurring downstream at Carter Bridge, which has a drainage basin area that is roughly $20 \%$ larger than Three Lynx. Table 3 shows a comparison of basin characteristics that demonstrate the landscape similarity between the two sites. Summary and statistical information of discharge data are listed in Appendix A.

Table 3. Comparison of basin characteristics between Clackamas above Three Lynx and Clackamas at Carter Bridge sites

\begin{tabular}{|l|l|l|}
\hline \multicolumn{1}{|c|}{ Metric } & \multicolumn{1}{|c|}{$\begin{array}{c}\text { Clackamas at } \\
\text { Carter Bridge }\end{array}$} & \multicolumn{1}{c|}{$\begin{array}{c}\text { Clackamas at } \\
\text { Oregon City }\end{array}$} \\
\hline $\begin{array}{l}\text { Drainage Basin } \\
\text { Area }\end{array}$ & $1,274 \mathrm{~km}^{2}$ & $1,538 \mathrm{~km}^{2}$ \\
\hline Drainage Density & $1.9 \mathrm{~km}^{2}$ & $1.9 \mathrm{~km}^{2}$ \\
\hline $\begin{array}{l}\text { Mean Basin } \\
\text { Slope }\end{array}$ & 14.1 Degrees & 15.5 Degrees \\
\hline $\begin{array}{l}\text { Total Length of } \\
\text { Mapped Streams } \\
\text { in Basin }\end{array}$ & $932 \mathrm{~km}$ & $1,106 \mathrm{~km}$ \\
\hline $\begin{array}{l}\text { Mean Annual } \\
\text { Precipitation }\end{array}$ & $185.4 \mathrm{~cm}$ & $190 \mathrm{~cm}$ \\
\hline $\begin{array}{l}\text { Percentage of } \\
\text { Impervious Area }\end{array}$ & $0.023 \%$ & $0.019 \%$ \\
\hline $\begin{array}{l}\text { Percent Forest } \\
\text { Area }\end{array}$ & $89.9 \%$ & $87.8 \%$ \\
\hline $\begin{array}{l}\text { Percent Urban } \\
\text { Area }\end{array}$ & $0.39 \%$ & $0.39 \%$ \\
\hline
\end{tabular}


$\mathrm{km}=$ kilometers, $\mathrm{km}^{2}=$ square kilometers, $\mathrm{cm}=$ centimeters $*$ Data obtained from U.S. Geological Survey, 2016, The StreamStats program (USGS, 2016), which incorporates National Land Cover Database data from NLCD 2011

\subsubsection{Precipitation Data}

Daily point station regional precipitation data were obtained from the National Climate Data Center (NCDC), Carbon Dioxide Information Analysis Center (CDIAC) and Oak Ridge National Laboratory, Oak Ridge, Tennessee website (Menne et Al., 2013). Precipitation data collected by the NCDC are part of the United States Historical Climatology Network (USHCN) and a subset of the U.S. Cooperative Observer Network operated by the National Oceanographic Atmospheric Administration (NOAA) and National Weather Service (NWS). Location of daily precipitation stations are shown in Figure 2. Data were downloaded from the NCDC website (http://www.usclimatedata.com/climate/portland/oregon/united-states/usor0275). Summary statistics and cumulative water-year data for precipitation totals at these stations are listed in Appendix B.

\subsubsection{Clackamas Basin Land Cover Data}

Land cover upstream of Clackamas Basin at Carter Bridge (Figure 2) encompasses roughly $1,540 \mathrm{~km}^{2}$ (about 63\%) of the Clackamas River Basin. The Oregon City reach (Figure 2) comprises $2,437 \mathrm{~km}^{2}$, this lower portion of the reach flows through 
agricultural lands and densely-populated areas, land cover classifications for the basin are listed in Table 3.

Table 4. Land Cover Information for Carter Bridge and Oregon City Watersheds

\begin{tabular}{|c|c|c|}
\hline Metric & $\begin{array}{c}\text { Clackamas at } \\
\text { Carter Bridge }\end{array}$ & $\begin{array}{c}\text { Clackamas at } \\
\text { Oregon City }\end{array}$ \\
\hline $\begin{array}{c}\text { Drainage Basin } \\
\text { Area }\end{array}$ & $1,538 \mathrm{~km}^{2}$ & $2,437 \mathrm{~km}^{2}$ \\
\hline $\begin{array}{c}\text { Drainage } \\
\text { Density }\end{array}$ & $1.9 \mathrm{~km} / \mathrm{km}^{2}$ & $1.9 \mathrm{~km} / \mathrm{km}^{2}$ \\
\hline $\begin{array}{c}\text { Mean Basin } \\
\text { Slope }\end{array}$ & 15.5 Degrees & 4.21 Degrees \\
\hline $\begin{array}{c}\text { Total Length of } \\
\text { Mapped }\end{array}$ & $1,106 \mathrm{~km}$ & $1,803 \mathrm{~km}$ \\
\hline $\begin{array}{c}\text { Mean Annual } \\
\text { Precipitation }\end{array}$ & $190 \mathrm{~cm}$ & $185 \mathrm{~cm}$ \\
\hline $\begin{array}{c}\text { Percentage of } \\
\text { Impervious }\end{array}$ & $0.02 \%$ & $1.3 \%$ \\
\hline $\begin{array}{c}\text { Percent Forest } \\
\text { and Shrub land } \\
\text { Area }\end{array}$ & $98 \%$ & $8.0 \%$ \\
\hline $\begin{array}{c}\text { Percent } \\
\text { Agricultural }\end{array}$ & $0 \%$ & $3.0 \%$ \\
\hline $\begin{array}{c}\text { Percent Urban } \\
\text { Area }\end{array}$ & $0.39 \%$ & $1 \%$ \\
\hline $\begin{array}{c}\text { Percent } \\
\text { Herbaceous }\end{array}$ & $1 \% \%$ \\
\hline
\end{tabular}

$\mathrm{km}=\mathrm{kilometers}, \mathrm{km}^{2}=$ square kilometers, $\mathrm{cm}=$ centimeters

*Data obtained from U.S. Geological Survey, 2016, The StreamStats program (USGS, 2016), which incorporates National Land Cover Database data from NLCD 2011 


\section{Methods}

\subsection{Wet Season and Dry Season Period Delineation}

To account for seasonal variability, stream flow data collected were separated by dividing the water year (from October 1 to September 30 ) into two separate 6 -month periods; the "wet season" (October-March) and the "dry season" (April-September). This is a typical division of seasons in marine west-coast climates (Cannon and Whitfield, 2001). A hyetograph of mean monthly precipitation totals measured at the Clackamas above Three Lynx precipitation station for the period of study are shown in Figure 3. Monthly totals were used to determine storm categorization as occurring in the wet or dry season.

The Köppen Climate Classification System, the most widely-used system for classifying the world's climates, describes the climate in the Pacific Northwest as a Mediterranean climate. Its categories are based on the annual and monthly averages of temperature and precipitation. Mediterranean climates receive rain primarily during the winter season from mid-latitude cyclones. Extreme summer aridity is caused by the sinking air of the subtropical highs and may exist for up to 5 months (Pidwirny, 2006).

Weather patterns in Northwest Oregon, west of the Cascades, are characterized by a mild climate, with moderate but near-continuous winter rainfall, dry summers, seasonal snowfall in the higher elevations and occasional low-elevation snowfall. 
Normal winter temperature lows are often in the 20s Fahrenheit (around - 6 to -7

degrees Celsius), but average in the mid 30s Fahrenheit (around 0 degrees Celsius).

Mean monthly rainfall amounts measured at Clackamas above Three Lynx, Oregon Precipitation Station from water years 2006-2012 (Figure 3) are provided as evidence to support the decision of the months selected to delineate the Wet Season and Dry Season; the monthly totals are also tabled in Appendix B.

Appendix C lists the summary and statistical information of wet and dry season turbidity and discharge data.

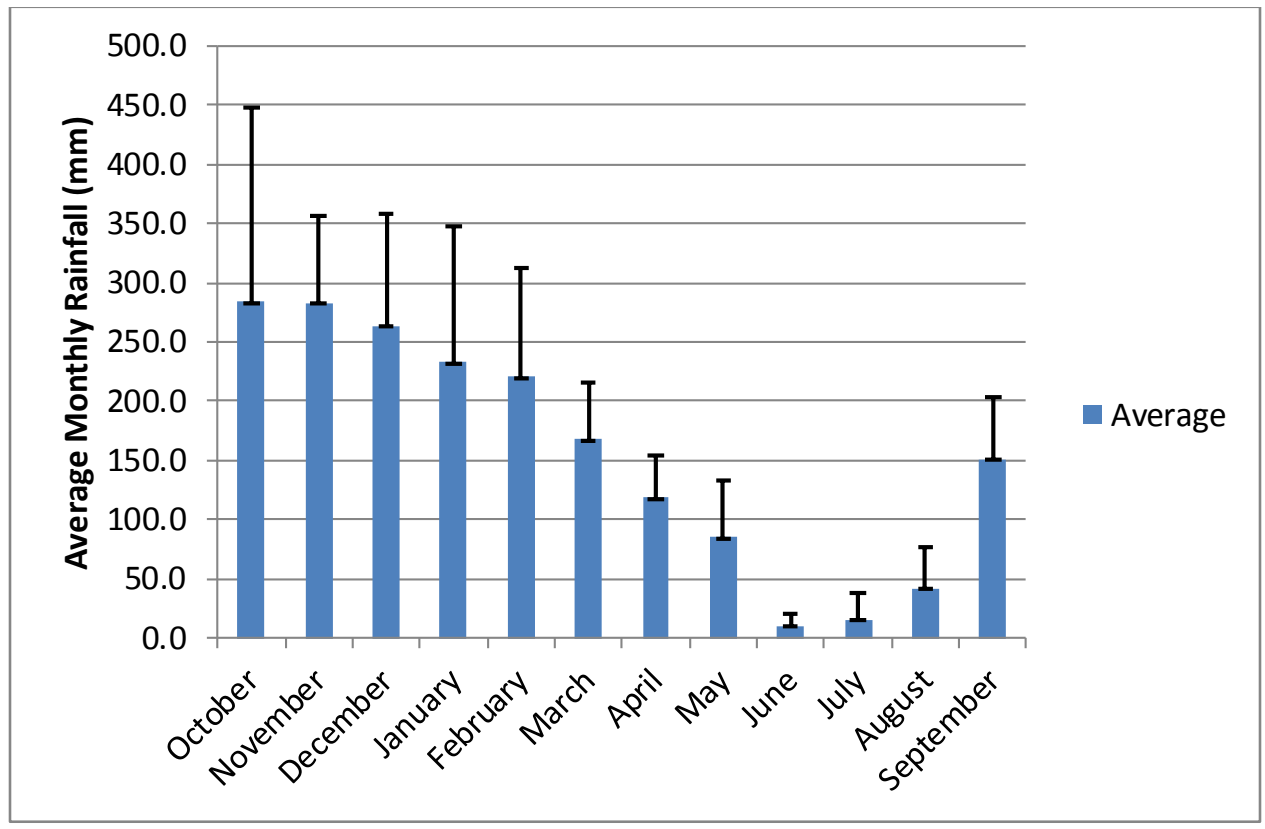

Figure 4. Hyetograph showing monthly average rainfall amount and standard deviation for water years 2006-2012 measured at Clackamas above Three Lynx, Oregon Precipitation Station, (Data from National Climate Data Center (NCDC), Carbon Dioxide Information Analysis Center (CDIAC) and Oak Ridge National Laboratory, Oak Ridge, Tennessee), mm=millimeters 


\subsubsection{Storm Selection and Identification}

A total of 41 storm events occurring in water years 2006 to 2012 were selected for analysis. Of these 41 events, 33 occurred during the wet season (October - March) and eight occurred during the dry season (April - September). Storms were selected using the following criteria (Figure 5):

1. A period of baseflow preceding the rising limb of the hydrograph

2. An recognizable peak discharge in the storm hydrograph

3. A return to baseflow condition following the storm event

Baseflow separation techniques using the U.S. Geological Survey PART program (Rutledge, 1993), were used to determine periods of baseflow preceding and following each selected storm event. The program PART uses streamflow partitioning to estimate a daily record of base flow under the streamflow record. The method designates baseflow to be equal to streamflow on days that fit a requirement of antecedent recession, linearly interpolates base flow for other days, and is applied to a long period of record to obtain an estimate of the mean rate of ground-water discharge (Ruthledge, 1993). PART was compared to six other baseflow separation techniques using data from 65 North American catchments (Eckhardt, 2008). Mean baseflow indices ( $\mathrm{BFI}$ ) ranged from 0.49 to 0.70 (PART BFI= 0.69), correlation between the different sets of $\mathrm{BFI}$ values ranged from 0.85 to 1.00 (PART=0.96) and standard 
deviations (SD) ranged from 0.10 to 0.18 , with SD for PART being 0.18 (Eckhardt,

2008). A fundamental problem is that the true BFI are unknown, but for purposes of this study PART is a suitable method for determining periods of baseflow before and after storm events in the Clackamas Basin.

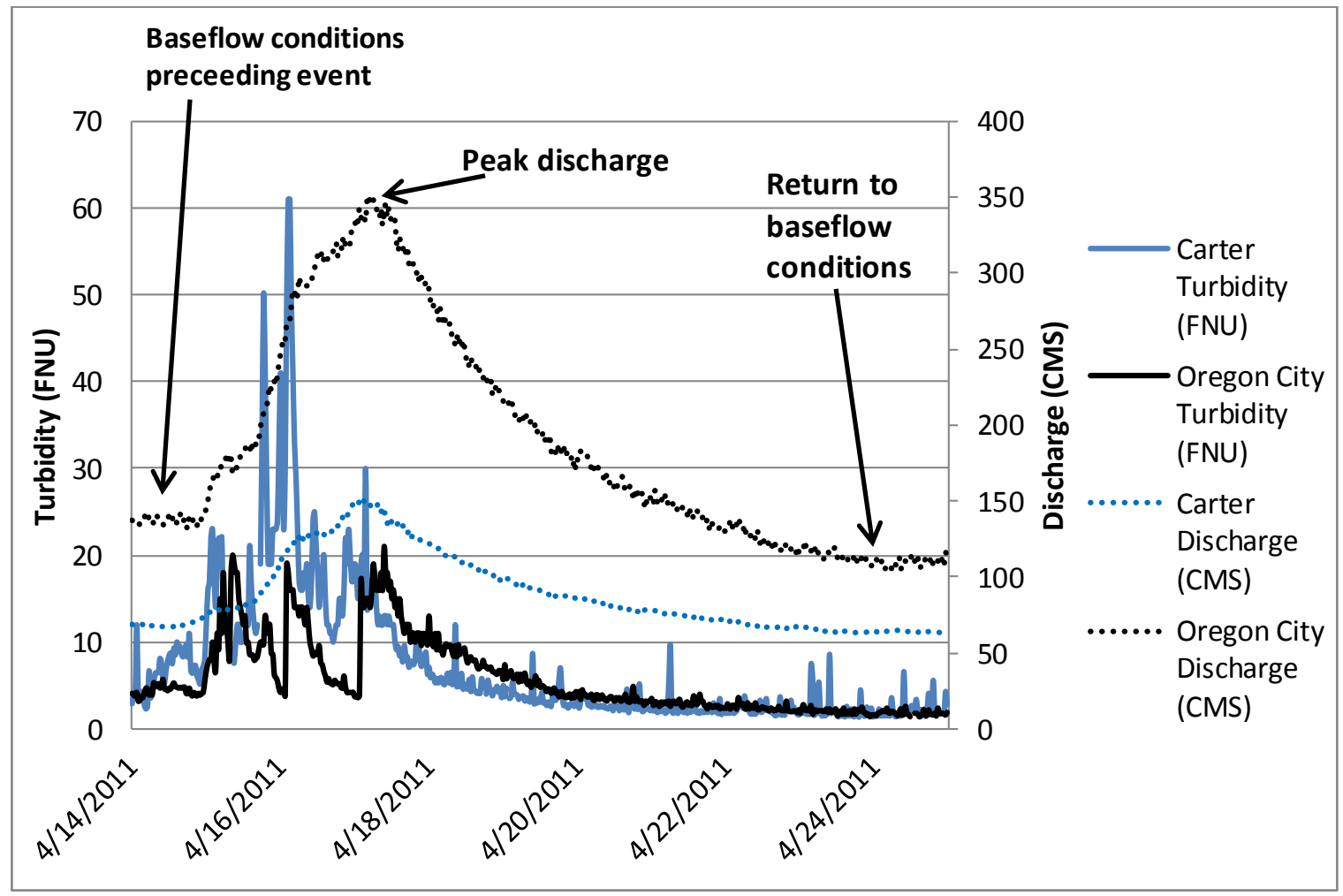

Figure 5. An example of a storm hydrograph and turbidity at Carter Bridge and Oregon City showing baseflow preceding and following a storm event.

Storms are identified by the water year (WY) and sequentially in the order that they occur during the WY. For example, the first storm in WY 2006 is named "2006.1" and the third storm in WY 2012 is identified as "2012.3". Storm identification and dates 
of each event for Carter Bridge and Oregon City are listed in Appendix D. Figure 6 is an example of a storm event hydrograph occurring in late January to early-February 2012, showing discharge and turbidity measured at both the Carter Bridge and Oregon City sites.

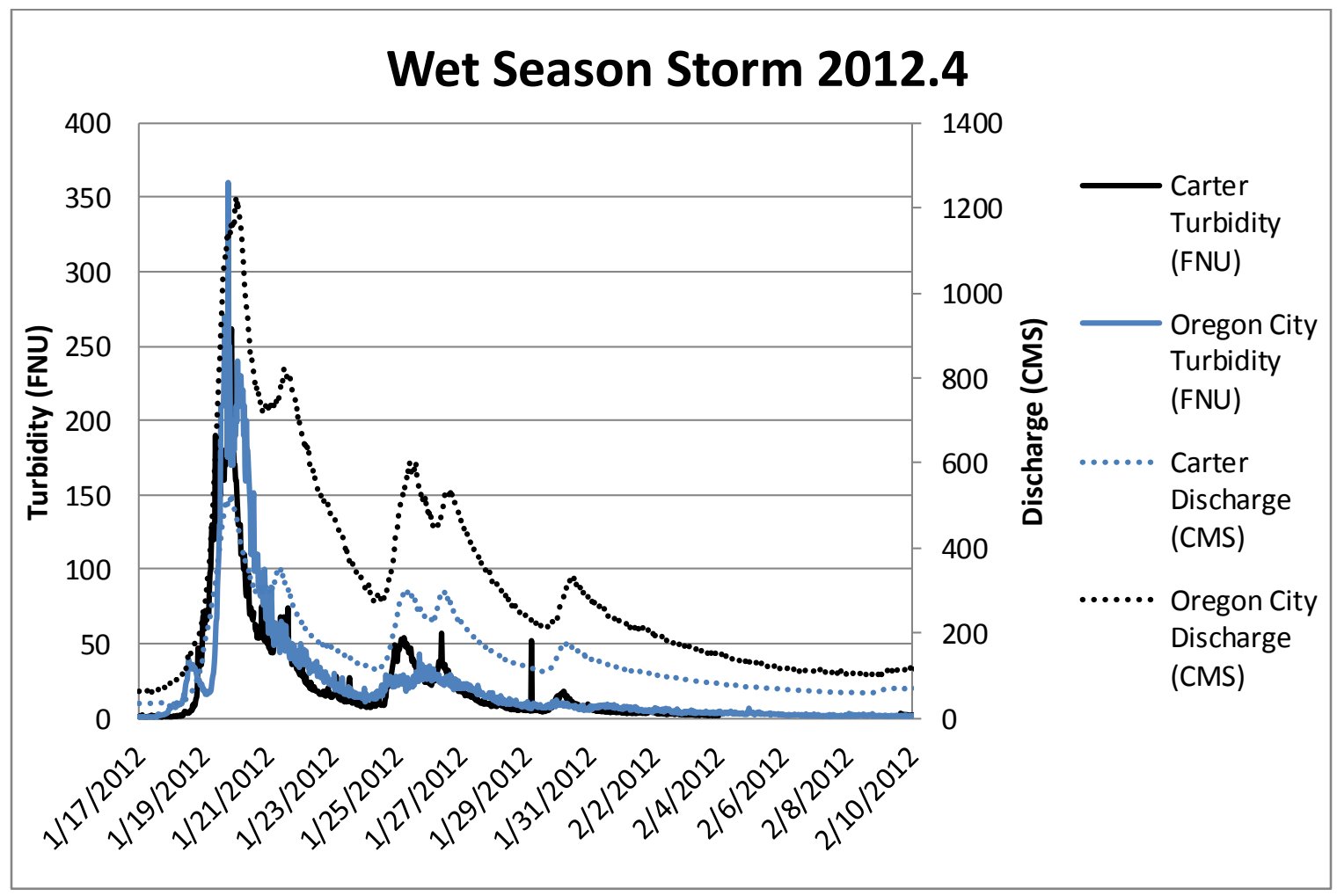

Figure 6. Example of "Wet Season Storm 2012.4" storm events hydrograph and turbidity graphs. FNU=Formazin Nephelometric Units, CMS=cubic meters per second

\subsubsection{Hysteresis Index}


A hysteresis index $(\mathrm{HI})$ was used to quantify the magnitude and direction of the hysteretic effect present in the discharge and turbidity relationship. The $\mathrm{HI}$ compares the turbidity values measured at the midpoint of discharge of the rising and falling limbs of the storm event hydrograph (Lawler et al., 2006). The HI assigns a positive direction for clockwise hysteresis (C), when turbidity is higher at the midpoint on the rising limb of the storm hydrograph than on the falling (recession) limb at the same discharge and assigns a negative value for counterclockwise (CC) hysteresis when the opposite is true. When no hysteresis is present, $\mathrm{HI}$ is given a zero value. $\mathrm{HI}$ standardizes a specific discharge at the midpoint of the storm hydrograph on the rising and falling limbs and expresses the magnitude and direction of the hysteresis symmetrically in a single number. The $\mathrm{HI}$ index is also used to assess whether or not seasonal differences exist between the storm responses at the two stations. The midpoint of discharge was calculated using the following equation:

$$
Q_{\text {mid }}=k\left(Q_{\max }-Q_{\min }\right)+Q_{\min }
$$

where $Q_{\text {mid }}$ is the discharge at the midpoint between $Q_{\max }$, the peak discharge during the event, and $Q_{\min }$, the discharge prior to the rise in the hydrograph preceding the event. The $k$ value $(0.5)$ represents the position at which the hysteresis loop is assessed in relation to discharge during the event. Figure 6 depicts a representation of the points on a storm hydrograph and turbidity graph that are used to calculate HI. Turbidity values measured at these specific discharges were used to calculate the HI. The two turbidity values at $\mathrm{Q}_{\text {mid }}$ called $T \mathrm{TU}_{\mathrm{RL}}$ on the rising limb of the hydrograph and $\mathrm{TU}_{\mathrm{FL}}$ the turbidity 
value associated with $Q_{\text {mid }}$ on the falling limb of the hydrograph are interpolated and $\mathrm{HI}_{\text {mid }}$ calculated as:

For clockwise hysteresis (Figure 7) where:

$\mathrm{TU}_{\mathrm{RL}}>\mathrm{TU} \mathrm{FL}_{\mathrm{FL}} \mathrm{HImid}=\left(\mathrm{TU}_{\mathrm{RL}} \mathrm{TU}_{\mathrm{FL}}\right)-1$

For counterclockwise hysteresis where:

$\left.\mathrm{TU}_{\mathrm{RL}}<\mathrm{TU}_{\mathrm{FL}}, \mathrm{HImid}=\left(-1 / \mathrm{TU}_{\mathrm{RL}} / \mathrm{TU}_{\mathrm{FL}}\right)\right)+1$

this method was utilized to investigate turbidity dynamics in an urban stream in the United Kingdom by Lawler and others, 2006.

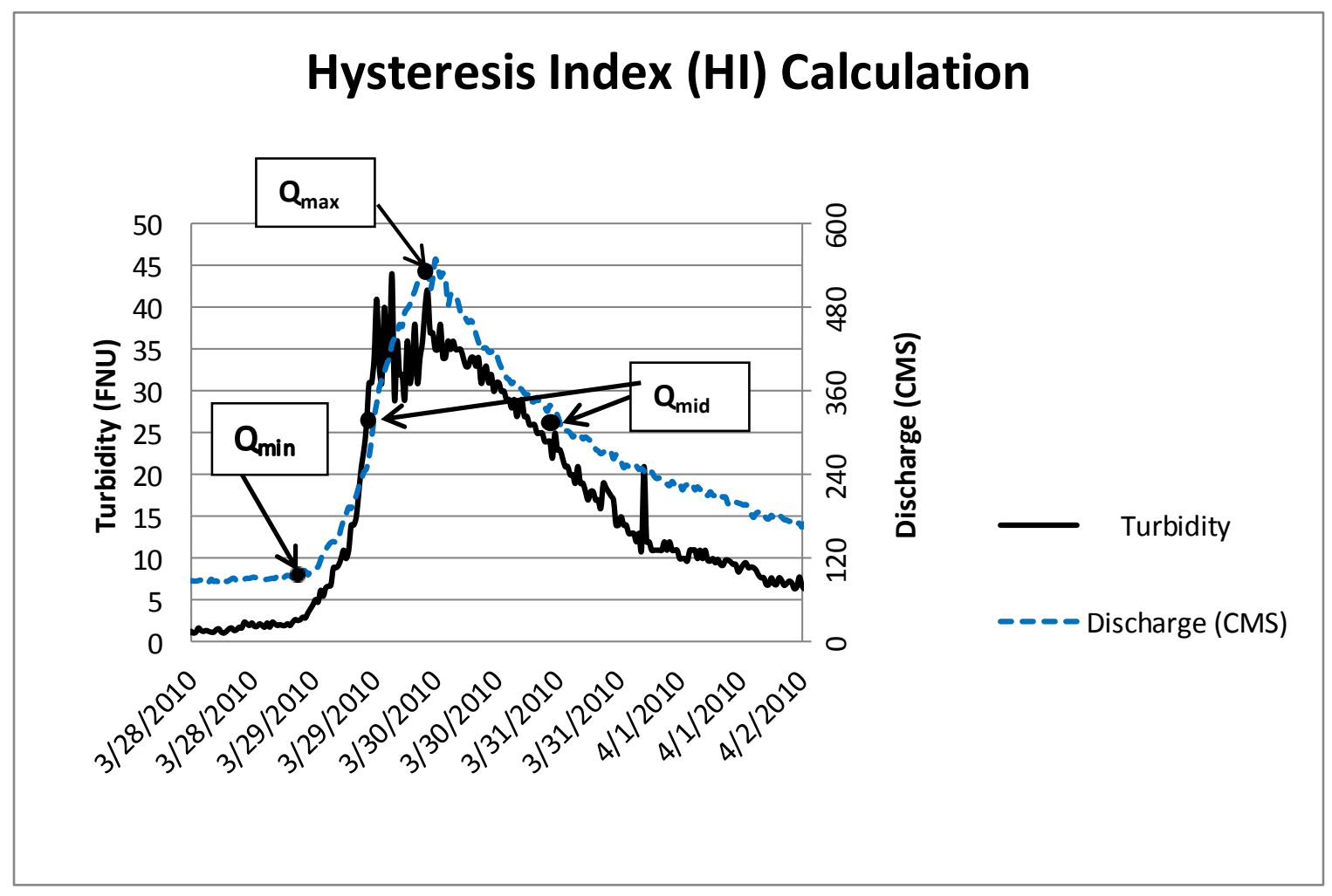


Figure 7. Example diagram using data from storm event at Oregon City occurring from $3 / 38 / 2010$ to $4 / 2 / 2010$ (event \# 2010.4), showing points on hydrograph where concurrent turbidity values measured at specific discharges points during an event were used to calculate a hysteresis index (HI). Qmin =the discharge prior to the rise in the hydrograph preceding the event; Qmid = the discharge at the midpoint between , Qmin and Qmax = the peak discharge during the event; FNU=Formazin Nephelometric Units; CMS=cubic meters per second

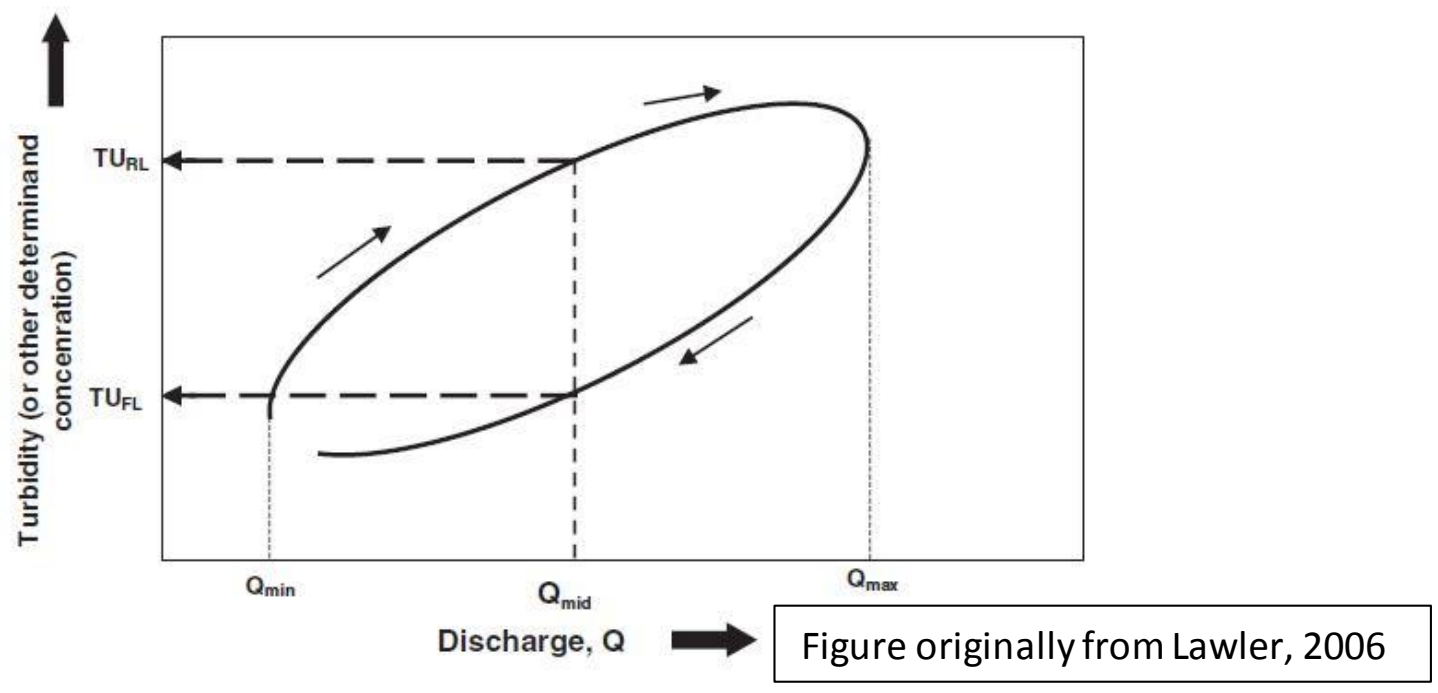

Figure 8. Schematic diagram depicting clockwise hysteresis using equations 1 and 2. TURL =Turbidity on the rising limb of the hydrograph, TU FL = Turbidity on the falling limb of the hydrograph Qmin =the discharge prior to the rise in the hydrograph preceding the event, Qmid =the discharge at the midpoint between , Qmin= prior to the beginning of the rise in the hydrograph, Qmax=the peak discharge during the event

\subsubsection{Antecedent Hydro-meteorological Conditions}

Precipitation amount and soil moisture are important controlling factors for storm runoff amounts (Sun et al., 2002). The antecedent precipitation index (API) was used to account for a composite measure of water storage in the basin including 
depression storage, surface water conditions and also as a way to gage soil moisture conditions prior to a rainfall runoff event. Several researchers have used API as a variable in rainfall runoff models and other studies as a method to describe soil moisture conditions (Fedora and Beschta, 1989, Ali et. al, 2010, Onderka et.al, 2012). API was calculated for $3,5,7,14$, and 30 days as:

$\mathrm{API}_{\mathrm{n}}=\sum_{i}^{n} P i$

Where $n$ is the number of days for which API is calculated starting from the day of an event and $P i$ in millimeters per day is the total precipitation on the $i$ th day before the event. These API indices were selected in effort to test a range of API values to represent soil moisture conditions for use in the multiple linear regression analysis.

\subsubsection{GIS Land Cover Data Analysis along River Channel}

GIS analysis was used to identify land cover type within a 100 and 200-meters of the main Clackamas River channel. This was done to categorize the land use of the riparian zone near the Carter Bridge and Oregon City water quality monitoring stations. Land cover classification data near the riparian zone will provide additional information that could further explain differences in turbidity due to runoff during storms between the two stations. The 2011 National Land Cover Database (NLCD) was used for this analysis. The NLCD provides spatial reference and descriptive data for characteristics of the land surface (Homer et al., 2012). 
The following methods were used calculate land cover near the main stem Clackamas River to create 100 and 200-meter buffers of the Clackamas River:

1. The USGS StreamStats basin delineation tool was used to create shape files of the watersheds upstream of each site.

2. A 2011 NLCD Land Cover of the State of Oregon that also contained National Hydrologic Dataset (NHD) Layer the was obtained from USGS data base

3. The "Clip" tool in Arc GIS (version 10.4.1) was used to "Clip" the shape files delineating the Clackamas Basin

4. The Clackamas River was selected from the Attribute Table and 100 and 200 meter buffers were created using the "Buffer" tool

5. The "Tabulate Area" function was then used to calculate land cover types within each of the buffers

6. "dbf" files created where then opened in Excel to tabulate the calculated land cover areas.

Land cover type within the selected buffer distances were calculated to characterize land-use near each turbidity monitoring site 


\subsubsection{Statistical Analysis}

\section{Paired t-test}

A paired t-test comparing $\mathrm{HI}$ values between storm events at the Carter Bridge and Oregon City sites was performed using the R statistical software (version 3.0.2).

The paired t-test was used to test the null hypothesis $\mathrm{H}_{0}$, and the alternative hypothesis $\mathrm{H}_{\mathrm{a}}$ :

$\left(H_{\circ}\right)$ : Calculated hysteresis index during selected storm events is the same at both sites.

$\left(H_{a}\right)$ : Calculated hysteresis index during selected storm events are not the same at both sites

Calculated hysteresis indexes during each storm event analyzed for this study were compared.

The null hypothesis $\left(\mathrm{H}_{0}\right)$ was rejected if the $p$-value from the paired t-test was less than or equal to 0.05 . Test statistics and results for each comparison are listed in Appendix D.

\subsubsection{Shapiro-Wilk Test}

The Shapiro-Wilk test was performed on turbidity and discharge values used for multiple linear regression analysis. Transformations such as logarithms are used to better meet the assumptions of parametric analysis (normality, linearity, and constant variances) and they are used as a diagnostic tool to aid in the identification of outliers 
and extreme data points. Shapiro Wilk test values for turbidity and log transformed turbidity are listed in Appendix F. Transformed and untransformed turbidity values were compared and log transformed turbidity values were used for model development. Log transformed values better met the conditions for normality tests.

\subsubsection{Regression analysis}

Multiple linear regression (MLR) was used to determine which explanatory variables or combination of variables best correlate with turbidity during storm events. Variable selection was performed using backward stepwise selection. Backward stepwise linear regression in $\mathrm{R}$ (version 3.0.2) was used to select the best model to determine which independent variable or group of variables best explain turbidity response during storm events. Linear regression models were developed that related the change in turbidity during storm events to measurable physical conditions and meteorological parameters. When evaluating the importance of a set of independent variables for prediction of a dependent variable, a stepwise technique is important in exploring behavior in a process-response model. Any attempt to develop a model of this form is limited by implicit assumptions of data normality, problems of multi-collinearity amongst the independent variables and serial correlation in the residuals (Foster, 1978). Independent variables used for developing the models are listed below in Table 5, and data table matrices used for Carter Bridge and Oregon City multiple linear regression models are shown in Appendix G. 
Model selection was performed in $\mathrm{R}$ which uses Akaike Information Criteria (AIC) as a best-fit measure for model selection. The following hydrological and meteorological variables were used as independent variables:

1. Change in stream flow $(\Delta Q)$

2. 3, 5, 7, 14, 30-day antecedent precipitation index (API\#)

3. Total precipitation (P) amounts measured during storms events 
Table 5. Independent variables used for model development

\begin{tabular}{|c|c|c|}
\hline Parameter & Symbol & Unit of Measure \\
\hline Change in Discharge & $(\Delta \mathrm{Q})$ & $\mathrm{mm}$ (total) \\
\hline Total Precipitation & $\mathrm{P}$ & $\mathrm{mm}$ (total) \\
\hline $\begin{array}{c}\text { 3-Day antecedent } \\
\text { precipitation }\end{array}$ & API3 meters per second $\left.\mathrm{m}^{3} / \mathrm{sec}\right)$ \\
\hline $\begin{array}{c}\text { 5-Day antecedent } \\
\text { precipitation }\end{array}$ & API5 & $\mathrm{mm}$ (total) \\
\hline $\begin{array}{c}\text { 7-Day antecedent } \\
\text { precipitation }\end{array}$ & API7 & $\mathrm{mm}$ (total) \\
\hline $\begin{array}{c}\text { 14-Day antecedent } \\
\text { precipitation }\end{array}$ & API14 & $\mathrm{mm}$ (total) \\
\hline $\begin{array}{c}\text { 30-Day antecedent } \\
\text { precipitation }\end{array}$ & API30 & $\mathrm{mm}$ (total) \\
\hline
\end{tabular}

The combination of variables (or variable) that provides the "best fit" in the regression analysis will be considered the major hydrological and meteorological control best determines turbidity during storm events.

\subsubsection{Model Diagnostics}

A number of graphical and statistical tools were used to examine the results of regression models. Leverage is a measure of an "outlier" in the $\mathrm{x}$ direction. It is a function of the distance from the ith $x$ value to the middle (mean) of the $x$ values used in the regression (Helsel, 2002). The Durbin Watson and Bruessch-Godfrey tests were performed on the final models to check for serial autocorrelation of the residuals. In 
regression analysis, variance may be biased because of dependence of the error residuals as a result of serial autocorrelation (Helsel and Hirsch, 2002). Serial autocorrelation is correlation between a data point and its adjacent points in a time series (Helsel and Hirsch, 2002).

Another model diagnostic tool is Cook's distance. Cook's distance measures the effect of a particular data point. Points with a large Cook's distance should be examined closely and considered for deletion. When cases are outside of the Cook's distance they are influential to the regression results. The regression results are altered if we exclude those cases. The Durbin Watson and Bruesch-Godfrey tests were performed on the final models to check for serial autocorrelation of the residuals. 


\section{Results}

\subsection{Summary of Turbidity Data}

In water years (WY) 2006-2012 the mean daily turbidity at Carter Bridge was 5.1 FNU, and the mean daily turbidity at Oregon City was 4.5 FNU with a standard deviation of 18.5 and 14.2, respectively. Median turbidity at Carter Bridge and Oregon City was 1.5 FNU and 1.4 FNU, respectively with an inter-quartile range of 2.7 FNU at both sites. Minimum daily turbidity during the study period was $0 \mathrm{FNU}$ at both sites, and the maximum daily turbidity during the study period at both sites was $340 \mathrm{FNU}$. Figure 8 illustrates the range of log turbidity values at Carter Bridge and Oregon City during water years 2006-2012. Turbidity values were log transformed for improved visual comparison. Summary statistics of turbidity values during the study period are in AppendixA. 


\section{Carter Bridge and Oregon City 2006-2012}

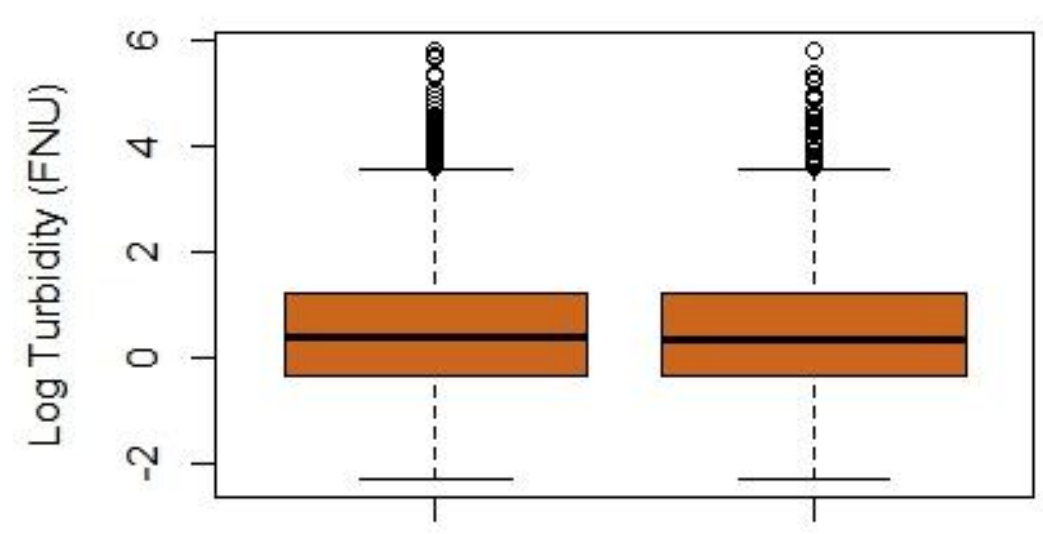

\section{Carter Bridge Oregon City}

Figure 9. Boxplot Comparison of Mean Daily Log Turbidity at Carter Bridge and Oregon City for Study Period ( $n=41)$

In water years (WY) 2006-2012 the mean daily turbidity at Carter Bridge and Oregon City during the "Wet Season" was 8.2 FNU and the mean daily turbidity at Oregon City was 7.3 FNU, with a standard deviation of 22.6 and 19.5 respectively. Median turbidity at Carter Bridge and Oregon City was 2.2 FNU and 2.4 FNU, respectively with an inter-quartile range of 4.0 FNU at Carter Bridge and 5.0 at Oregon City. Minimum daily "Wet Season" turbidity during the study period was $0.0 \mathrm{FNU}$ at both sites. The maximum daily turbidity during the "Wet Season" was 340 FNU at both sites. Figure 9 is a boxplot comparing turbidity at both sites during the "Wet Season" of water years 2006-2012. Turbidity values were log transformed to aide comparison. Summary 
statistics of turbidity "Wet and Dry Season" turbidity during the study period are shown in Appendix C.

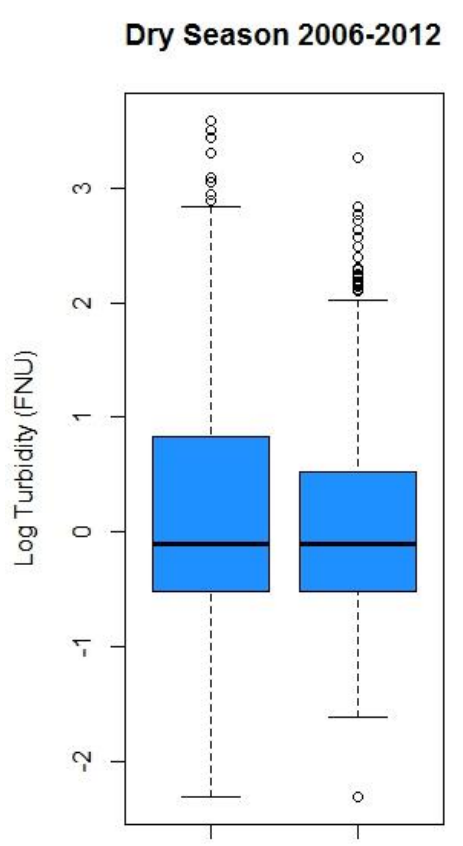

Carter Bridge Oregon City
Wet Season 2006-2012

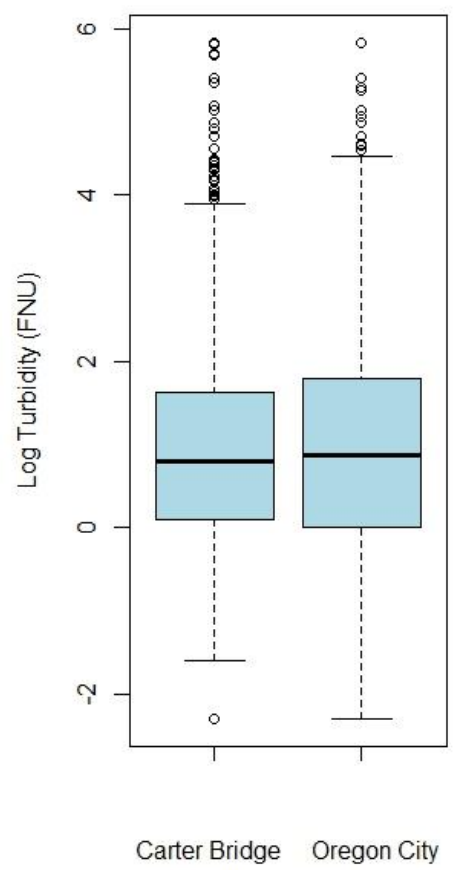

Figure 10. Boxplots showing log transformed mean daily turbidity measured at Carter Bridge and Oregon City during the Wet and Dry Season in water years 2006-2012

In water years WY 2006-2012 the mean daily turbidity during the "Dry Season" at Carter Bridge was 2.0 FNU and at Oregon City it was 1.6 FNU with a standard deviation of 3.1 and 2.1, respectively. Median turbidity at both sites was 0.9 FNU, with an inter-quartile range of 1.7 at Carter Bridge and 1.1 at Oregon City. Minimum daily turbidity during the study period was $0.0 \mathrm{FNU}$ at both sites. The maximum daily turbidity during the "Dry Season" was 36 FNU at Carter Bridge and 26 FNU at Oregon City. Figure 
10 illustrates an intrasite comparison of log transformed "Wet and Dry Season" turbidity at Carter Bridge and Oregon City during WY 2006-2012. Turbidity values were log transformed to aide comparison. Summary statistics of turbidity "Wet and Dry Season" turbidity during the study period are in shown in Appendix C.

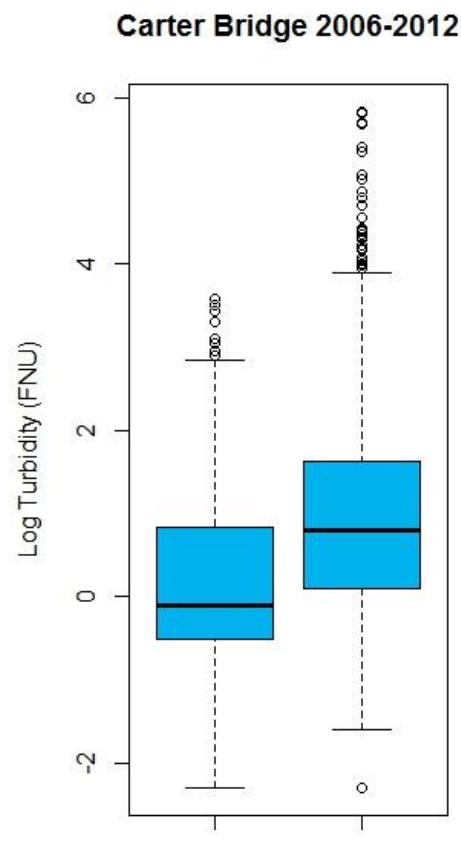

Dry Wet
Oregon City 2006-2012

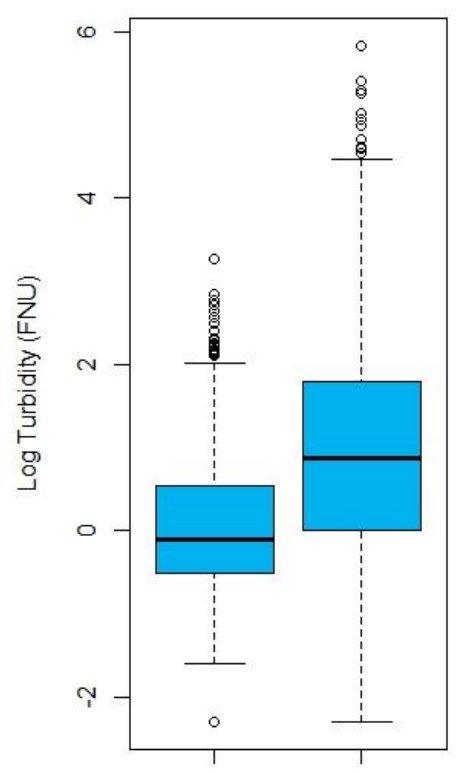

Dry Wet

Figure 11. Intrasite comparison of Turbidity in Wet and Dry Seasons from 2006-2012 at Carter Bridge and Oregon City

Turbidity values measured during the "Wet Season" were higher than those measured in the "Dry Season" at both sites. 


\subsection{Hysteresis Index by season and site}

The Carter Bridge site exhibited clockwise (C) hysteresis index (HI) in 38 of the 41 storm events (92.6\% of the time) and counter clockwise (CC) HI value in 3 events. The mean $\mathrm{HI}$ value for all storms at Carter Bridge was 1.86; the median $\mathrm{HI}$ value was 1.43 with a standard deviation of 2.25. HI values ranged from -2.25 to 9.00 . The lowest $\mathrm{HI}$ value occurred during storm 2006.8 from March 7, 2006 to March 12, 2009. The highest HI value occurred during storm 2006.7 from February 27, 2006 to March 5, 2006.

The Oregon City site exhibited clockwise hysteresis in 29 of the 41 storms $(73.1 \%$ of the time); counter clockwise in 11 and one storm's calculated HI was " 0 ". The mean $\mathrm{HI}$ value for all storms at Oregon City was 0.96 ; the median $\mathrm{HI}$ value was 0.39 with a standard deviation of 1.95. HI values ranged from -2.04 to 8.06 . The lowest HI value occurred during storm 2009.5 from May 4, 2009 to May 22, 2009. The highest HI value occurred during storm 2007.1 from October 31, 2006 to November 12, 2006.

$\mathrm{HI}$ values for the Carter Bridge and Oregon City and the data used to compute the values are shown in Appendix E.

The Carter Bridge site ( $n=41)$ had a mean HI of " 1.86 " and a standard deviation (SD) of " 2.25 ". By comparison Oregon City $(n=41)$ had a numerically smaller mean HI value of "0.96" (almost half) and a SD of "1.95". To test the hypothesis that HI values calculated for storms at Carter Bridge and Oregon City were associated with statistically significant different $\mathrm{HI}$ values a two-sided t-test was performed. Results are shown in Table 5. The 
assumption of equal variance was tested and satisfied via a Levene's $F$ test, $d f(39)=$ 1.17, $p$-value $=0.632$, results are shown in Table 6 . The two-sided t-test was associated with a statistically significant effect, $\mathrm{df}(39)=1.81, \mathrm{p}=0.078$. Thus Carter Bridge HI values were associated with a statistically significant larger HI than Oregon City. Box and whisker plots of calculated HI values are shown in Figure 11.

Table 6. Statistical Summary of Hysteresis Indices Calculated at Study Sites

\begin{tabular}{|l|l|l|l|l|l|}
\hline Site & $\begin{array}{l}\text { Hysteresis } \\
\text { Index (HI) } \\
\text { Values } \\
\text { Compared } \\
\text { (N) }\end{array}$ & $\begin{array}{l}\text { Degrees } \\
\text { of } \\
\text { Freedom } \\
\text { (df) }\end{array}$ & $\begin{array}{l}\text { Mean } \\
\text { Hysteresis } \\
\text { Index (HI) }\end{array}$ & $\begin{array}{l}\text { Standard } \\
\text { Deviation } \\
\text { (SD) }\end{array}$ & $\begin{array}{l}\text { Interquartile } \\
\text { Range (IQR) }\end{array}$ \\
\hline $\begin{array}{l}\text { Carter } \\
\text { Bridge }\end{array}$ & 41 & 39 & 1.86 & 2.25 & 2.05 \\
\hline Oregon City & 41 & 39 & 0.96 & 1.95 & 2.19 \\
\hline
\end{tabular}

Table 7. Results of Two-sided t-Test and

Levene's F-Test of Hysteresis Indices

\begin{tabular}{|l|l|l|l|}
\hline $\begin{array}{l}\text { Statistical } \\
\text { Test }\end{array}$ & Test Value & $\begin{array}{l}\text { Degrees of } \\
\text { Freedom } \\
\text { (df) }\end{array}$ & p-value \\
\hline $\begin{array}{l}\text { Two-sided t- } \\
\text { Test }\end{array}$ & 1.81 & 39 & 0.078 \\
\hline $\begin{array}{l}\text { Levene's F- } \\
\text { Test }\end{array}$ & 1.17 & 39 & 0.632 \\
\hline
\end{tabular}




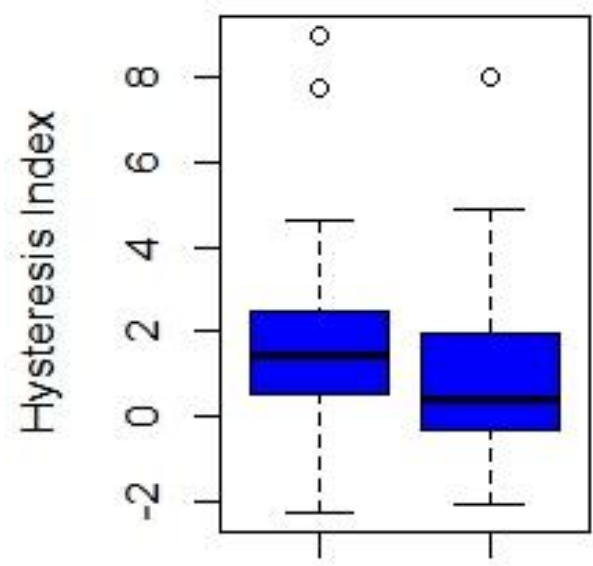

Carter Bridge Oregon City

Figure 12. Boxplot of Calculated HI Values from Clackamas River at Carter Bridge and Clackamas at Oregon City $(n=41)$

\section{Land Cover Characterization within 100 and 200 Meter Buffer Zones of Clackamas River}

The majority of land cover within both the 100 and 200-meter buffers for both sites was forest land (combined deciduous, evergreen and mixed) and shrub-scrub types, with Carter Bridge having slightly over $85 \%$ and Oregon City having 59.3\% forested land cover in the 100 -meter buffer. Carter Bridge is classified as $85 \%$ forest and shrub-scrub land cover and Oregon City classified as having 65.9\% within the 200meter buffer zone. 
The Carter Bridge site has about 0.3\% developed land of (combined low, medium and high) and Oregon City has about 2.7\% developed land in the 100-meter buffer, which is roughly an order of magnitude greater by comparison. The Carter Bridge site has slightly over $0.2 \%$ developed land (combined low, medium and high) and Oregon City has about $4.0 \%$ developed land in the 200 -meter buffer, which is about double an order of magnitude distinction by comparison. The Carter Bridge buffers have no agricultural or wetland land cover, however and Oregon City has about 1.5\% agricultural and $7.6 \%$ wetland land cover within the 100-meter buffer zone and 3.0\% agricultural and $5.9 \%$ wetland land cover within the 200-meter buffer. Numerically the differences in land cover within the 100 and 200-meter buffers for developed, agricultural land and wetland may not appear to be very substantial; however this difference represents a potential contrast in sediment and particulate matter available to be entrained into the river channel during storm events. Table 4 lists land cover classification percentages within the 100 and 200 meter buffers at both sites. 
Table 8. Percentage of Land Cover Classifications within 100-meter and 200meter Buffer Regions of the Clackamas River at Carter Bridge and Oregon City based on 2011 National Land Cover Data (NLDC)

\begin{tabular}{|c|c|c|c|c|c|c|c|c|}
\hline $\begin{array}{l}\text { Site and } \\
\text { Buffer } \\
\text { Region }\end{array}$ & $\begin{array}{l}\text { Open } \\
\text { Water }\end{array}$ & $\begin{array}{l}\text { Developed } \\
\text { Open } \\
\text { Space }\end{array}$ & $\begin{array}{l}\text { Developed } \\
\text { Land }\end{array}$ & $\begin{array}{l}\text { Barren } \\
\text { Land }\end{array}$ & $\begin{array}{l}\text { Forest } \\
\text { and } \\
\text { Shrub } \\
\text { Land }\end{array}$ & Grassland & $\begin{array}{l}\text { Cultivated } \\
\text { Crops and } \\
\text { Hay }\end{array}$ & Wetlands \\
\hline $\begin{array}{c}\text { Carter } \\
\mathbf{1 0 0 -} \\
\text { meter } \\
\text { Buffer }\end{array}$ & $4.4 \%$ & $9.3 \%$ & $0.3 \%$ & $0.4 \%$ & $85.0 \%$ & $0.5 \%$ & $0.0 \%$ & $0.0 \%$ \\
\hline $\begin{array}{c}\text { Oregon } \\
\text { City 100- } \\
\text { meter } \\
\text { Buffer }\end{array}$ & $15.0 \%$ & $10.1 \%$ & $2.7 \%$ & $1.6 \%$ & $59.3 \%$ & $2.4 \%$ & $1.4 \%$ & $7.6 \%$ \\
\hline $\begin{array}{c}\text { Carter } \\
\mathbf{2 0 0 -} \\
\text { meter } \\
\text { Buffer }\end{array}$ & $2.2 \%$ & $8.0 \%$ & $0.3 \%$ & $0.3 \%$ & $88.7 \%$ & $0.5 \%$ & $0.0 \%$ & $0.0 \%$ \\
\hline $\begin{array}{c}\text { Oregon } \\
\text { City 200- } \\
\text { meter } \\
\text { Buffer }\end{array}$ & $8.7 \%$ & $8.8 \%$ & $4.0 \%$ & $1.1 \%$ & $65.9 \%$ & $2.8 \%$ & $3.0 \%$ & $5.9 \%$ \\
\hline
\end{tabular}




\subsection{Relation between discharge and turbidity}

The best model results for Carter Bridge and Oregon City storm events were as follows:

Carter Bridge: $\log \Delta$ Turb $=-2.75+1.24 * \log \Delta \mathrm{Q}$

Oregon City: $\log \Delta \mathrm{Turb}=-2.19+0.96 * \log \Delta \mathrm{Q}$

The best model results for Carter Bridge and Oregon City Wet Season storm events were as follows:

Carter Bridge: $\log \Delta$ Turb $=-3.32+1.37 * \log \Delta \mathrm{Q}$

Oregon City: $\log \Delta$ Turb $=--1.96+0.95 * \log \Delta \mathrm{Q}$

The best model results for Carter Bridge and Oregon City Dry Season storm events were as follows:

Carter Bridge: $\log \Delta \mathrm{Turb}=-0.57+0.75 * \log \Delta \mathrm{Q}$

Oregon City: $\log \Delta \mathrm{Turb}=-4.70+1.25 * \log \Delta \mathrm{Q}+0.03 * \mathrm{API3}$

Where $\log \Delta T b=\operatorname{Ln}$ of the change in turbidity during the storm event, $\log \Delta Q=\operatorname{Ln}$ of the change in discharge during the storm event and $A P I 3=3$ day antecedent precipitation index 


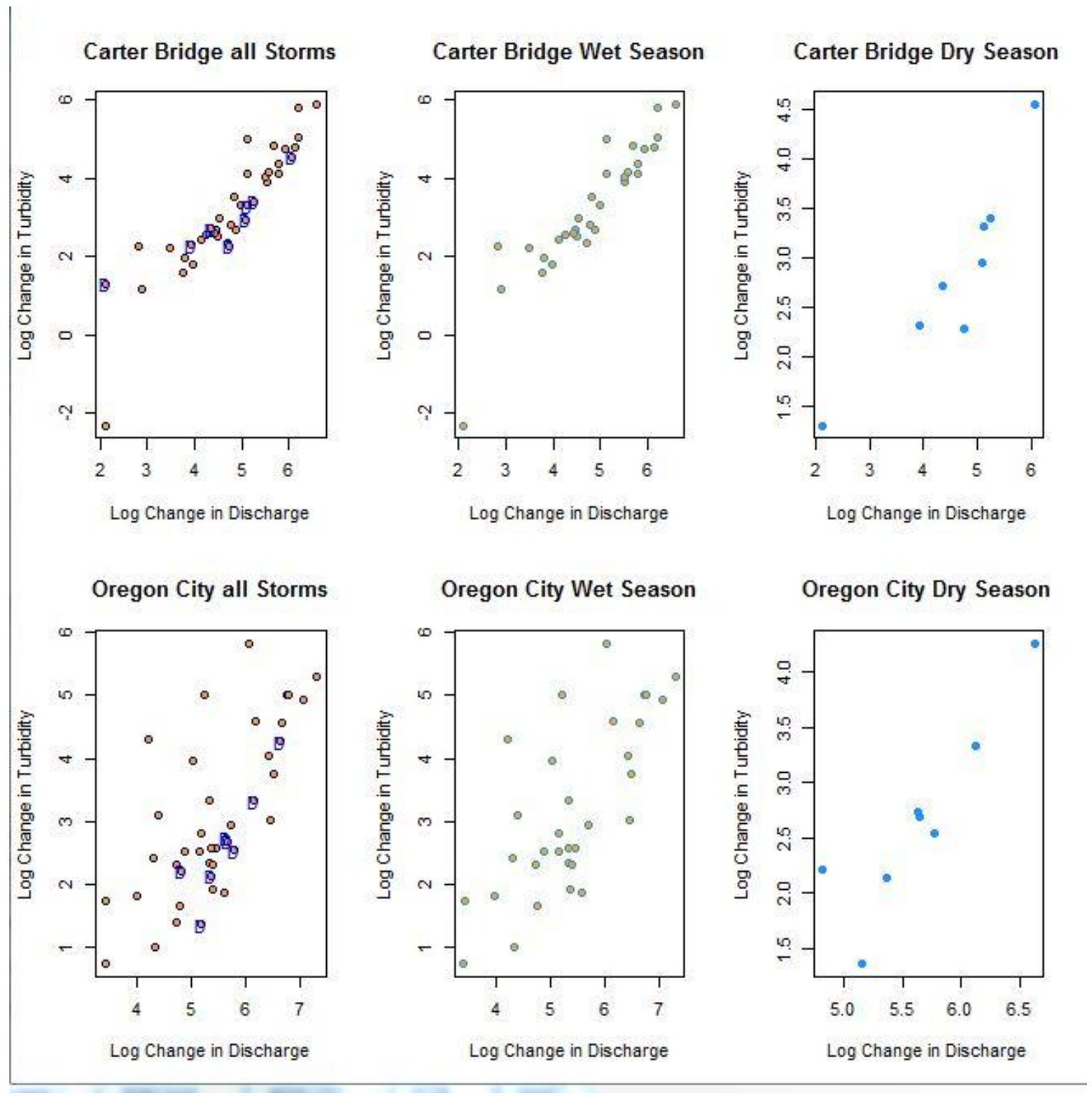

Figure 13. Scatter plots of linear fit of $\log \Delta T b$ as a function of $\log \Delta Q$ at Clackamas at Carter Bridge and Oregon City, Log $\Delta$ Turb=Natural Log (Ln) of change in turbidity from initial increase to peak value during storm event, $\Delta Q=$ Natural $\log (\mathrm{Ln})$ of change in discharge from initial increase to peak value during storm event, " $D$ " denotes dry season storm event All variables from Table 5 were used for the stepwise regression models and "Log $\Delta Q$ " alone produced the best fit. Model summaries are listed in Table 10. 
Table 9.

Data used for Carter Bridge Multiple Linear Regression Analysis-

\begin{tabular}{|c|c|c|c|c|c|c|c|c|c|c|}
\hline Event & Dates & $\mathbf{T b}_{\text {initial }}$ & $\mathrm{Tb}_{\text {Max }}$ & deltaT & LogDTb & $\mathbf{Q}_{\text {initial }}$ & Qmax & DeltaQ & LogDQ & Precipitation $_{\text {Total }}$ \\
\hline 2006.1 & $11 / 10-11 / 24$ & 1.8 & 8.9 & 7.1 & 1.96 & 38.8 & 85.8 & 44.7 & 3.80 & 48.3 \\
\hline 2006.2 & $12 / 18-12 / 26$ & 0.8 & 81.0 & 80.2 & 4.38 & 41.1 & 354.0 & 328.7 & 5.79 & 113.3 \\
\hline 2006.3 & $12 / 29-1 / 6$ & 45.0 & 160.0 & 115.0 & 4.74 & 224.3 & 560.7 & 376.1 & 5.93 & 188.0 \\
\hline 2006.4 & $1 / 28-2 / 11$ & 17.0 & 45.0 & 28.0 & 3.33 & 91.2 & 219.7 & 145.6 & 4.98 & 181.6 \\
\hline 2006.5 & $2 / 27-3 / 5$ & 3.2 & 13.0 & 9.8 & 2.28 & 48.1 & 62.6 & 16.7 & 2.82 & 35.3 \\
\hline 2006.6 & $3 / 7-3 / 12$ & 2.6 & 2.7 & 0.1 & -2.30 & 51.0 & 57.8 & 8.2 & 2.11 & 61.0 \\
\hline 2006.7 & $4 / 2-4 / 30$ & 1.9 & 12.0 & 10.1 & 2.31 & 49.8 & 103.6 & 51.5 & 3.94 & 119.4 \\
\hline 2007.1 & $10 / 31-11 / 12$ & 0.6 & 330.0 & 329.4 & 5.80 & 20.6 & 515.4 & 494.9 & 6.20 & 315.2 \\
\hline 2007.2 & $12 / 8-12 / 22$ & 2.1 & 130.0 & 127.9 & 4.85 & 53.0 & 356.8 & 293.1 & 5.68 & 186.2 \\
\hline 2007.3 & $12 / 22-1 / 7$ & 4.9 & 68.0 & 63.1 & 4.14 & 86.4 & 253.2 & 169.1 & 5.13 & 241.8 \\
\hline 2007.4 & $3 / 24-4 / 1$ & 2.0 & 8.1 & 6.1 & 1.81 & 69.9 & 122.9 & 53.2 & 3.97 & 60.2 \\
\hline 2008.1 & $10 / 15-10 / 26$ & 0.2 & 20.0 & 19.8 & 2.99 & 19.4 & 113.3 & 94.0 & 4.54 & 104.9 \\
\hline 2008.2 & $11 / 15-11 / 26$ & 1.0 & 16.0 & 15.0 & 2.71 & 38.5 & 186.0 & 87.5 & 4.47 & 101.6 \\
\hline 2008.3 & $12 / 1-12 / 16$ & 0.9 & 120.0 & 119.1 & 4.78 & 34.0 & 501.2 & 466.1 & 6.14 & 162.1 \\
\hline 2008.4 & $5 / 14-5 / 28$ & 5.8 & 36.0 & 30.2 & 3.41 & 113.3 & 283.2 & 191.4 & 5.25 & 82.5 \\
\hline 2009.1 & $10 / 27-11 / 5$ & 0.5 & 3.8 & 3.3 & 1.19 & 22.5 & 40.8 & 18.2 & 2.90 & 64.5 \\
\hline 2009.2 & $11 / 5-11 / 18$ & 1.6 & 52.0 & 50.4 & 3.92 & 33.7 & 288.8 & 252.0 & 5.53 & 142.5 \\
\hline 2009.3 & $12 / 23-1 / 20$ & 0.8 & 150.0 & 149.2 & 5.01 & 29.2 & 194.3 & 167.9 & 5.12 & 326.7 \\
\hline 2009.4 & $2 / 21-3 / 17$ & 0.6 & 13.0 & 12.4 & 2.52 & 28.9 & 122.3 & 90.6 & 4.51 & 256.0 \\
\hline 2009.5 & $5 / 4-5 / 31$ & 3.4 & 31.0 & 27.6 & 3.32 & 96.8 & 258.0 & 169.9 & 5.14 & 137.9 \\
\hline 2010.1 & $11 / 5-11 / 16$ & 0.7 & 5.6 & 4.9 & 1.59 & 26.8 & 69.4 & 43.3 & 3.77 & 152.4 \\
\hline 2010.2 & $12 / 9-12 / 30$ & 0.6 & 17.0 & 16.4 & 2.80 & 25.5 & 145.3 & 119.1 & 4.78 & 182.6 \\
\hline 2010.3 & $1 / 4-1 / 15$ & 3.4 & 14.0 & 10.6 & 2.36 & 84.1 & 192.8 & 110.7 & 4.71 & 80.5 \\
\hline 2010.4 & $3 / 28-4 / 5$ & 2.6 & 59.0 & 56.4 & 4.03 & 56.1 & 303.0 & 247.5 & 5.51 & 148.1 \\
\hline 2010.5 & $6 / 1-6 / 22$ & 1.8 & 21.0 & 19.2 & 2.95 & 52.4 & 216.6 & 164.5 & 5.10 & 164.6 \\
\hline 2010.6 & $9 / 14-10 / 2$ & 0.7 & 4.4 & 3.7 & 1.31 & 21.1 & 30.0 & 8.4 & 2.13 & 76.7 \\
\hline 2011.1 & $10 / 20-10 / 30$ & 0.7 & 10.0 & 9.3 & 2.23 & 18.3 & 55.2 & 32.9 & 3.49 & 108.2 \\
\hline 2011.2 & $11 / 13-11 / 26$ & 2.5 & 16.0 & 13.5 & 2.60 & 38.8 & 122.3 & 84.1 & 4.43 & 145.8 \\
\hline 2011.3 & $11 / 26-12 / 7$ & 2.4 & 14.0 & 11.6 & 2.45 & 39.6 & 111.0 & 62.0 & 4.13 & 88.9 \\
\hline 2011.4 & $12 / 7-12 / 25$ & 1.4 & 66.0 & 64.6 & 4.17 & 42.2 & 305.8 & 265.6 & 5.58 & 255.8 \\
\hline 2011.5 & $12 / 25-1 / 7$ & 3.9 & 17.0 & 13.1 & 2.57 & 51.0 & 121.2 & 70.5 & 4.26 & 91.7 \\
\hline 2011.6 & $1 / 11-2 / 2$ & 1.2 & 360.0 & 358.8 & 5.88 & 38.8 & 775.9 & 736.0 & 6.60 & 191.3 \\
\hline 2011.7 & $4 / 14-4 / 24$ & 6.8 & 22.0 & 15.2 & 2.72 & 68.8 & 151.8 & 77.6 & 4.35 & 67.8 \\
\hline 2012.2 & $11 / 21-12 / 26$ & 3.2 & 37.0 & 33.8 & 3.52 & 33.7 & 156.6 & 125.7 & 4.83 & 119.1 \\
\hline 2012.3 & $12 / 27-1 / 16$ & 1.2 & 120.0 & 118.8 & 4.78 & 23.5 & 481.4 & 458.7 & 6.13 & 229.9 \\
\hline 2012.4 & $1 / 17-2 / 10$ & 1.0 & 160.0 & 159.0 & 5.07 & 34.3 & 518.2 & 493.3 & 6.20 & 416.6 \\
\hline 2012.5 & $2 / 17-3 / 3$ & 1.3 & 16.0 & 14.7 & 2.69 & 59.2 & 187.5 & 130.5 & 4.87 & 175.0 \\
\hline 2012.6 & $3 / 9-3 / 27$ & 2.1 & 64.0 & 61.9 & 4.13 & 61.7 & 387.9 & 327.3 & 5.79 & 238.5 \\
\hline 2012.7 & $3 / 29-4 / 10$ & 15.0 & 110.0 & 95.0 & 4.55 & 101.7 & 512.5 & 430.4 & 6.06 & 134.9 \\
\hline 2012.8 & $4 / 15-5 / 13$ & 1.2 & 11.0 & 9.8 & 2.28 & 81.0 & 196.5 & 115.0 & 4.74 & 182.9 \\
\hline
\end{tabular}

Event-storm identification, $\mathrm{Tb}_{\text {initial }}$-turbidity at beginning of event in formazin nephelometric units (FNU), $\mathrm{Tb}_{\mathrm{Max}}$-Peak turbidity during event in formazin nephelometric units (FNU), deltaTb-change in turbidity from initial to peak in formazin nephelometric units (FNU), , LogDTb-log of deltaT [In(cubic meters per second)], $Q_{\text {initial }}$ - discharge at beginning of event [In(cubic meters per second)], Qmax-discharge Peak turbidity during 
event[In(cubic meters per second)], DeltaQ-change in discharge from initial to peak[In(cubic meters per second)] , LogDQ-log of DeltaQ[In(cubic meters per second)] , Precipitation $_{\text {Total }}$-total precipitation during event(millimeters))

Table 10. Data used for Oregon City Multiple Linear Regression Analysis

\begin{tabular}{|c|c|c|c|c|c|c|c|c|c|c|}
\hline Event & Dates & $T b_{\text {initial }}$ & $\mathrm{Tb}_{\max }$ & DeltaTb & LogDTb & $\mathbf{Q}_{\text {initial }}$ & $Q_{\max }$ & deltaQ & LogDQ & Precipitation $_{\text {Total }}$ \\
\hline 2006.1 & $11 / 10-11 / 24$ & 1.8 & 7.1 & 5.3 & 1.67 & 69.4 & 186.9 & 117.5 & 4.77 & 38.1 \\
\hline 2006.2 & 2 12/18-12/26 & 0.5 & 53.0 & 52.5 & 3.96 & 34.8 & 186.3 & 151.5 & 5.02 & 121.4 \\
\hline 2006.3 & 3 12/29-1/6 & 39.0 & 190.0 & 151.0 & 5.02 & 461.6 & 1305.4 & 843.8 & 6.74 & 5.1 \\
\hline 2006.4 & 4 1/27-2/11 & 8.1 & 30.0 & 21.9 & 3.09 & 136.8 & 218.3 & 81.6 & 4.40 & 13.5 \\
\hline 2006.5 & $2 / 27-3 / 5$ & 1.8 & 13.0 & 11.2 & 2.42 & 69.1 & 142.2 & 73.1 & 4.29 & 7.6 \\
\hline 2006.6 & 6 3/7-3/12 & 2.9 & 8.6 & 5.7 & 1.74 & 83.3 & 113.8 & 30.6 & 3.42 & 56.1 \\
\hline 2006.7 & 7 4/2-4/30 & 1.8 & 11.0 & 9.2 & 2.22 & 87.5 & 211.8 & 124.3 & 4.82 & 70.4 \\
\hline 2007.1 & 1 10/31 - 11/12 & 0.9 & 150.0 & 149.1 & 5.00 & 25.8 & 211.8 & 186.0 & 5.23 & 187.0 \\
\hline 2007.2 & 2 12/8-12/22 & 0.5 & 100.0 & 99.5 & 4.60 & 85.2 & 557.8 & 472.6 & 6.16 & 15.0 \\
\hline 2007.3 & 3 12/22-1/7 & 6.4 & 80.0 & 73.6 & 4.30 & 151.5 & 219.5 & 68.0 & 4.22 & 32.8 \\
\hline 2007.4 & 4 3/24-4/1 & 1.4 & 18.0 & 16.6 & 2.81 & 111.6 & 286.0 & 174.4 & 5.16 & 15.7 \\
\hline 2008.1 & 1 10/15-10/26 & 0.5 & 13.0 & 12.5 & 2.53 & 30.3 & 162.3 & 132.0 & 4.88 & 105.4 \\
\hline 2008.2 & 2 11/15- 11/26 & 0.7 & 14.0 & 13.3 & 2.59 & 54.7 & 288.8 & 234.2 & 5.46 & 108.7 \\
\hline 2008.3 & 3 12/1-12/16 & 2.8 & 98.0 & 95.2 & 4.56 & 72.2 & 841.0 & 768.8 & 6.64 & 100.8 \\
\hline 2008.4 & 4 5/14-5/28 & 0.6 & 16.0 & 15.4 & 2.73 & 158.9 & 436.1 & 277.2 & 5.62 & 49.0 \\
\hline 2009.1 & 1 10/27-11/5 & 0.4 & 6.6 & 6.2 & 1.82 & 26.5 & 80.1 & 53.7 & 3.98 & 63.0 \\
\hline 2009.2 & 2 11/5-11/18 & 2.7 & 23.0 & 20.3 & 3.01 & 58.1 & 688.1 & 630.0 & 6.45 & 117.9 \\
\hline 2009.3 & 3 12/23-1/20 & 0.9 & 340.0 & 339.1 & 5.83 & 43.3 & 464.4 & 421.1 & 6.04 & 193.3 \\
\hline 2009.4 & 4 2/21-3/17 & 0.5 & 11.0 & 10.5 & 2.35 & 47.6 & 252.3 & 204.7 & 5.32 & 144.5 \\
\hline 2009.5 & $5 / 4-5 / 31$ & 2.3 & 17.0 & 14.7 & 2.69 & 153.8 & 436.1 & 282.3 & 5.64 & 17.5 \\
\hline 2010.1 & $111 / 5-11 / 16$ & 1.0 & 11.0 & 10.0 & 2.30 & 39.1 & 152.6 & 113.5 & 4.73 & 97.3 \\
\hline 2010.2 & $212 / 9-12 / 30$ & 0.7 & 14.0 & 13.3 & 2.59 & 36.5 & 245.2 & 208.7 & 5.34 & 112.0 \\
\hline 2010.3 & $31 / 4-1 / 15$ & 4.2 & 11.0 & 6.8 & 1.92 & 148.4 & 365.3 & 216.9 & 5.38 & 60.9 \\
\hline 2010.4 & $43 / 28-4 / 5$ & 2.0 & 30.0 & 28.0 & 3.33 & 91.8 & 549.3 & 457.6 & 6.13 & 110.5 \\
\hline 2010.5 & $6 / 1-6 / 22$ & 2.3 & 15.0 & 12.7 & 2.54 & 116.4 & 438.9 & 322.5 & 5.78 & 94.5 \\
\hline 2010.6 & 6 9/14-10/2 & 0.6 & 2.7 & 2.1 & 0.74 & 24.5 & 54.7 & 30.2 & 3.41 & 65.3 \\
\hline 2011.1 & $10 / 20-10 / 30$ & 0.4 & 3.1 & 2.7 & 0.99 & 23.1 & 99.4 & 76.3 & 4.33 & 77.5 \\
\hline 2011.2 & $211 / 13-11 / 26$ & 1.6 & 30.0 & 28.4 & 3.35 & 75.9 & 280.9 & 205.0 & 5.32 & 92.5 \\
\hline 2011.3 & 3 11/26-12/7 & 2.0 & 12.0 & 10.0 & 2.30 & 76.5 & 294.5 & 218.0 & 5.38 & 53.9 \\
\hline 2011.4 & 4 12/7-12/25 & 2.1 & 45.0 & 42.9 & 3.76 & 90.3 & 753.2 & 662.9 & 6.50 & 177.0 \\
\hline 2011.5 & $12 / 25-1 / 7$ & 2.1 & 21.0 & 18.9 & 2.94 & 88.6 & 390.8 & 302.1 & 5.71 & 100.6 \\
\hline 2011.6 & $61 / 11-2 / 2$ & 1.5 & 200.0 & 198.5 & 5.29 & 74.2 & 1557.4 & 1483.2 & 7.30 & 134.6 \\
\hline 2011.7 & 7 4/14-4/24 & 4.5 & 13.0 & 8.5 & 2.14 & 137.3 & 351.1 & 213.8 & 5.37 & 55.9 \\
\hline 2012.1 & $111 / 10-11 / 21$ & 0.6 & 4.7 & 4.1 & 1.41 & 27.8 & 138.8 & 110.9 & 4.71 & 104.9 \\
\hline 2012.2 & $211 / 21-12 / 26$ & 3.6 & 16.0 & 12.4 & 2.52 & 55.5 & 228.8 & 173.3 & 5.16 & 116.1 \\
\hline 2012.3 & 3 12/27-1/16 & 0.3 & 150.0 & 149.7 & 5.01 & 35.1 & 906.1 & 871.0 & 6.77 & 131.6 \\
\hline 2012.4 & 4 1/17-2/10 & 1.9 & 140.0 & 138.1 & 4.93 & 68.8 & 1226.1 & 1157.3 & 7.05 & 216.7 \\
\hline 2012.5 & $2 / 17-3 / 3$ & 1.8 & 8.3 & 6.5 & 1.87 & 106.8 & 373.8 & 267.0 & 5.59 & 82.1 \\
\hline 2012.6 & 5 3/9-3/27 & 1.9 & 59.0 & 57.1 & 4.04 & 119.5 & 727.7 & 608.2 & 6.41 & 171.2 \\
\hline 2012.7 & 7 3/29-4/10 & 4.8 & 76.0 & 71.2 & 4.27 & 161.4 & 909.0 & 747.6 & 6.62 & 102.1 \\
\hline 2012.8 & $34 / 15-5 / 13$ & 1.8 & 5.7 & 3.9 & 1.36 & 131.7 & 305.8 & 174.2 & 5.16 & 103.4 \\
\hline
\end{tabular}

Event-storm identification, $\mathrm{Tb}_{\text {initial }}$-turbidity at beginning of event, $\mathrm{Tb}_{\mathrm{Max}}$-Peak turbidity during event, deltaTb-change in turbidity from initial to peak, LogDTb-log of deltaT, $\mathrm{Q}_{\text {initial }}$ - discharge at beginning of event, Qmax-discharge Peak turbidity during event, DeltaQ-change in discharge from initial to peak, LogDQ-log of DeltaQ, Precipitation Total- $^{-}$ total precipitation during event 
Linear models for Carter Bridge and Oregon City have $\mathrm{R}^{2}$ values of " 0.81 " and " 0.48 ", respectively. This illustrates that the log value of the change in discharge explains approximately $81 \%$ of the change in turbidity at Carter Bridge and approximately $48 \%$ of the change in turbidity at Oregon City.

Table 11. Change in Turbidity Model Summary

\begin{tabular}{|c|c|c|c|c|c|c|c|}
\hline Site & Estimate & $\begin{array}{l}\text { Standard } \\
\text { Error }\end{array}$ & t-value & $p$-value & $\begin{array}{l}\text { Multiple } \\
\mathrm{R}^{2}\end{array}$ & $\begin{array}{l}\text { Adjusted } \\
\mathrm{R}^{2}\end{array}$ & F-Statistic \\
\hline $\begin{array}{l}\text { Carter } \\
\text { Bridge } \\
\text { all } \\
\text { Storms } \\
(n=41)\end{array}$ & -2.74693 & 0.46679 & -5.885 & $1.276^{\wedge}(-15)$ & 0.82 & 0.81 & 170.4 \\
\hline $\begin{array}{l}\text { Carter } \\
\text { Bridge } \\
\text { Wet } \\
\text { Season } \\
\text { Storms } \\
(n=33)\end{array}$ & 1.3669 & 0.1046 & 13.072 & $6.388 \mathrm{e}-14$ & 0.85 & 0.85 & 170.9 \\
\hline $\begin{array}{l}\text { Carter } \\
\text { Bridge } \\
\text { Dry } \\
\text { Season } \\
\text { Storms } \\
(n=8)\end{array}$ & 0.7470 & 0.1313 & 5.688 & 0.001274 & 0.84 & 0.82 & 32.36 \\
\hline $\begin{array}{l}\text { Oregon } \\
\text { City all } \\
\text { Storms } \\
(n=41)\end{array}$ & -2.194 & 0.8564 & -2.562 & $2.761^{\wedge}(-7)$ & 0.50 & 0.48 & 38.4 \\
\hline $\begin{array}{l}\text { Oregon } \\
\text { City Wet } \\
\text { Season } \\
(n=33)\end{array}$ & 0.9528 & 0.1680 & 5.670 & $3.517 e-06$ & 0.52 & 0.50 & 32.15 \\
\hline $\begin{array}{l}\text { Oregon } \\
\text { City Dry } \\
\text { Season } \\
(n=8)\end{array}$ & $\mathrm{API}=0.029$ & 0.01492 & $\begin{array}{l}5.121 \\
1.961\end{array}$ & 0.004579 & 0.88 & 0.84 & 19.06 \\
\hline
\end{tabular}




\subsection{Model Diagnostics for both sites}

Diagnostic plots of linear regressions for Wet Season and Dry Season storms at Carter Bridge are shown in Figures $13 \mathrm{a}-\mathrm{b}$ and diagnostic plots of linear regressions for Wet Season and Dry Season storms at Oregon City are shown in Figures 14 a-b. Diagnostic plots of linear regressions for all storms at Carter Bridge and Oregon City are shown in Figures $15 a-b$, respectively. These diagnostic plots are useful checks to determine if the multiple linear regression model is adequately representative of the data. There are four different plots for each model

The Residuals vs. Fitted plots for both sites in show a random pattern above and below the horizontal line at the midpoint in each case

The normal quantile-quantile plots for all models appear to demonstrate a normal distribution for all models. The quantile-quantile plots for Oregon City shows strong visual evidence of being normally distributed. Shapiro-Wilk (SW) tests for normality results on final model variables and residuals are listed in Appendix F. 

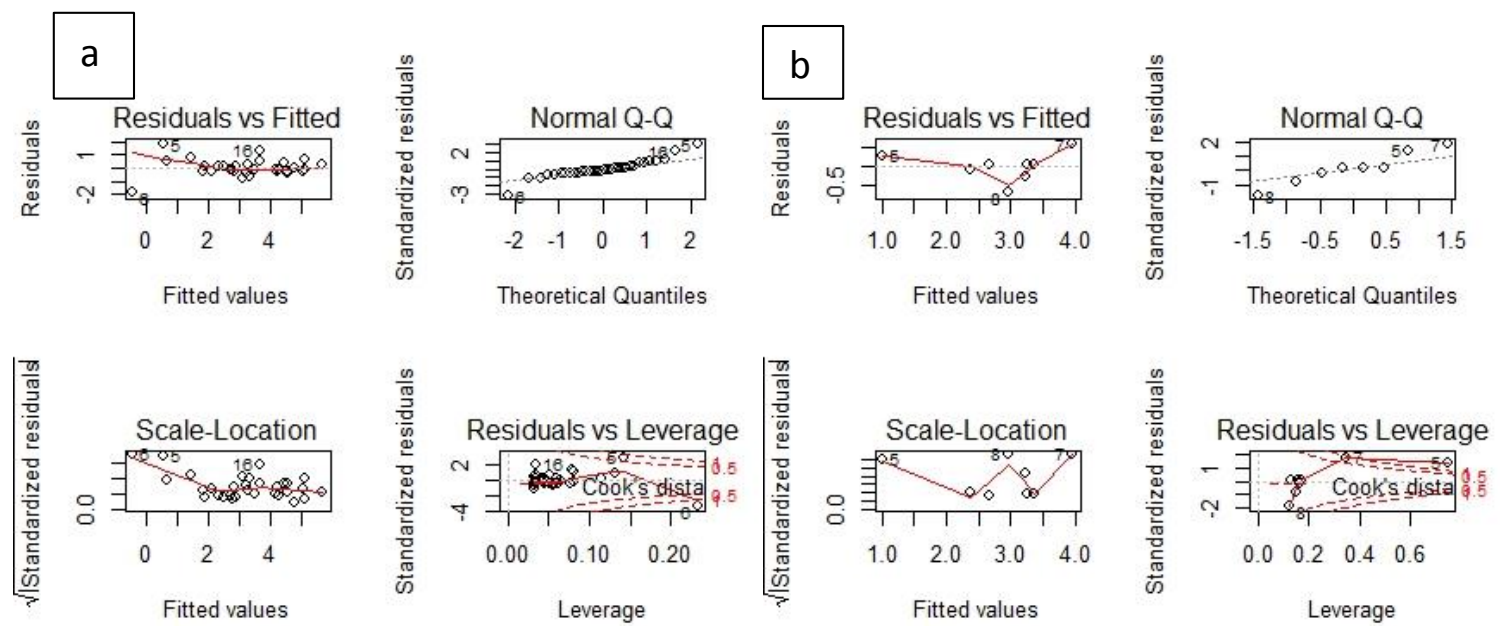

Figure 14. a-Diagnostic plots of Carter Bridge Wet Season model, bDiagnostic plots of Carter Bridge Dry Season model

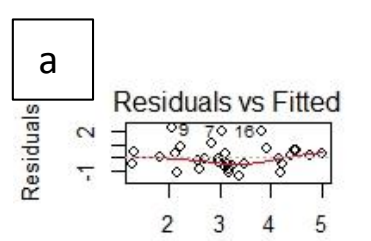

Fitted values

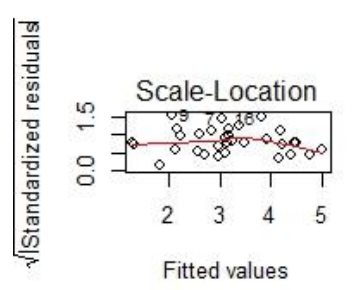

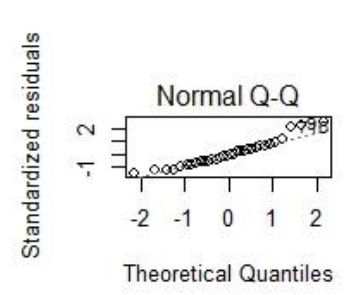
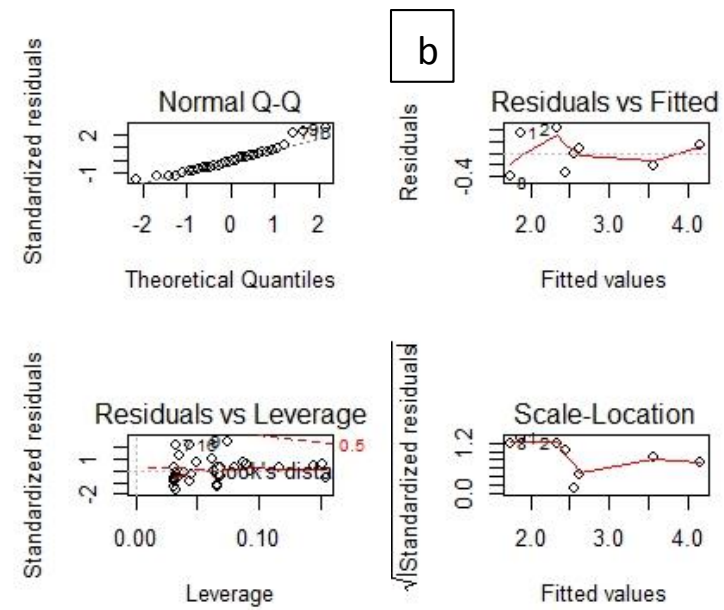

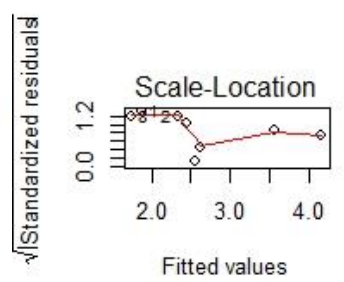

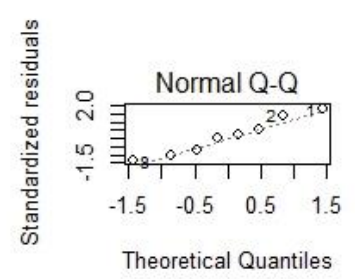

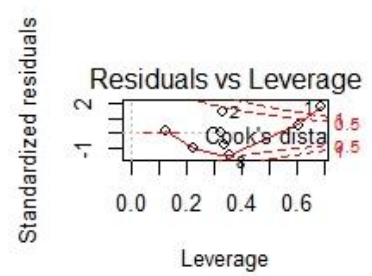

Figure 15. Diagnostic plots of Oregon City Wet Season model, b-Diagnostic plots of Oregon City Dry Season model 


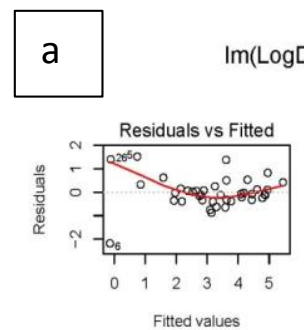

Fitted values

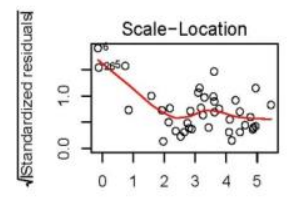

Fitted values
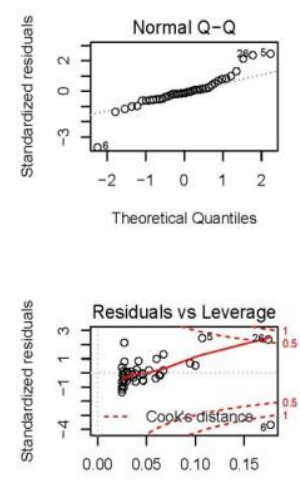

Leverage
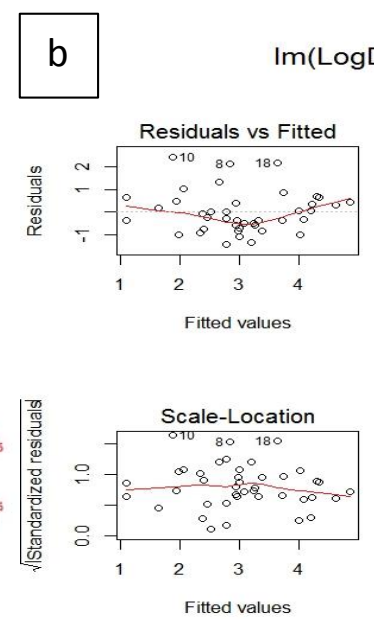

$\operatorname{Im}(\log D T \sim \log D Q)$
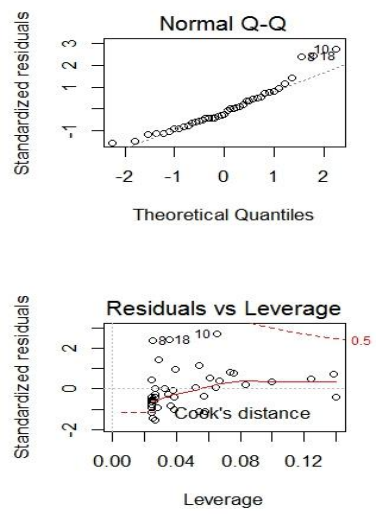

Figure 16. a-Diagnostic plots of Carter Bridge all Storms model, bDiagnostic plots of Oregon City all Storms model

The Residuals versus Leverage is used to look for any influential data points that can have a visible effect on the model. Within this plot we are looking for outlying values in the upper right or lower right corners. These outlying values represent data points which can be influential against a regression line. We are also looking for cases outside of a dashed line. The Carter Bridge plot (figure 15a)has two data points outside, but were not deleted ...in order to show distribution entire distribution of data points and the Oregon City plot 20d had no values outside of Cooks distance.

Results from covariance tests (Table 11) indicate that there is no strong evidence of serial autocorrelation in the residuals from either of the Carter Bridge and Oregon City models. 
Table 12. Results of Covariance Tests

\begin{tabular}{|c|c|c|c|c|}
\hline Site & $\begin{array}{l}\text { Breusch- } \\
\text { Godfrey }\end{array}$ & BG p-value & $\begin{array}{l}\text { Durbin Watson } \\
\text { (DW) }\end{array}$ & DW p-value \\
\hline $\begin{array}{l}\text { Carter Bridge } \\
\text { Final model }\end{array}$ & 1.5407 & 0.4629 & 2.3326 & 0.8474 \\
\hline $\begin{array}{l}\text { Oregon City } \\
\text { Final Model }\end{array}$ & 4.6004 & 0.1002 & 1.7762 & 0.2239 \\
\hline
\end{tabular}




\subsection{Turbidity Change During Storm Events}

Box and whisker plots the minimum turbidity prior to a storm event, peak turbidity during the storm and change in turbidity from the minimum to the peak during the event are shown in Figure 16. In the majority of the comparisons the turbidity readings between the two sites appear to be somewhat similar when comparing the seasonal storm events.
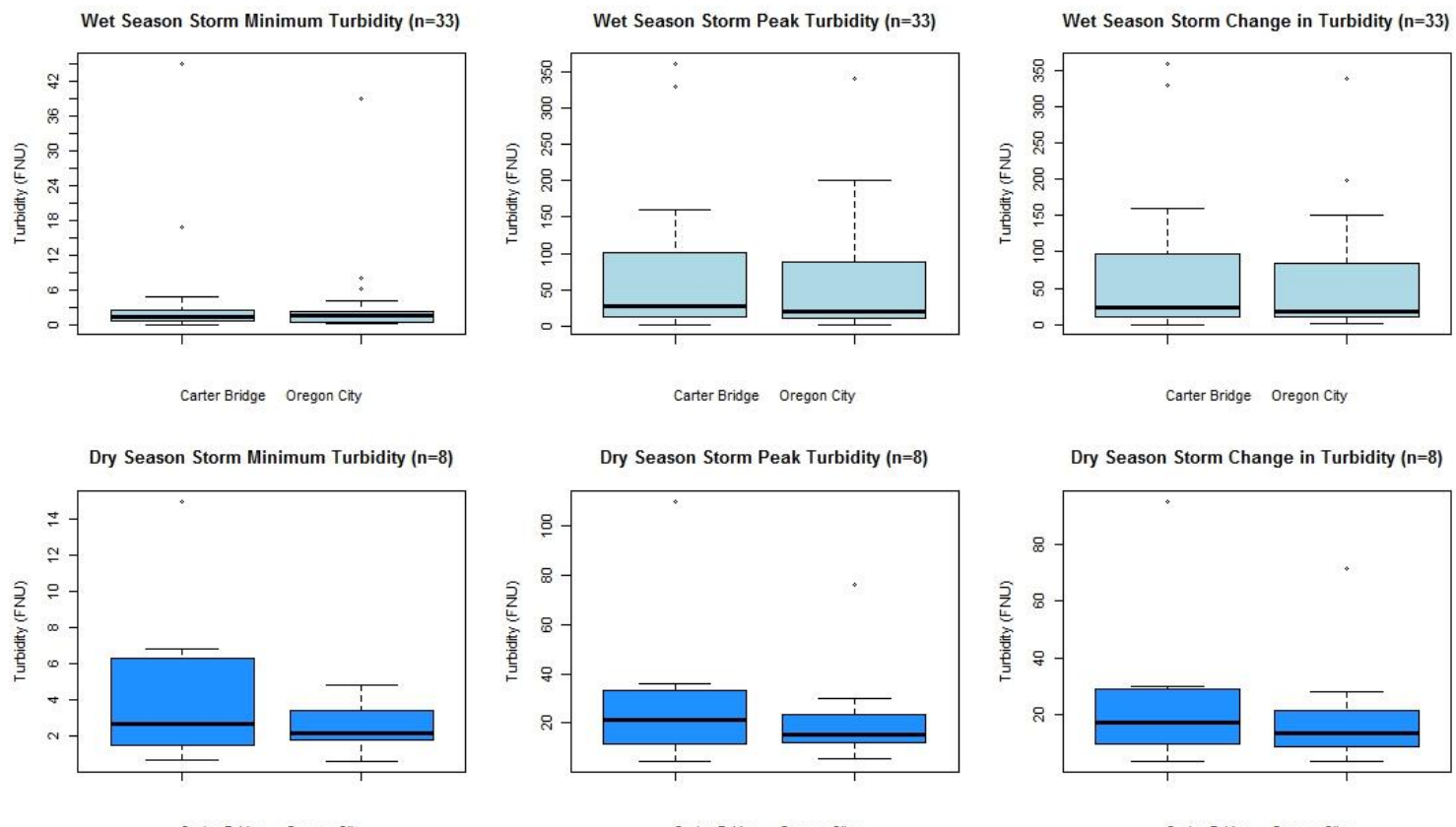

Dry Season Storm Change in Turbidity $(\mathrm{n}=8)$

Carter Bridge Oregon City

Carter Bridge Oregon City

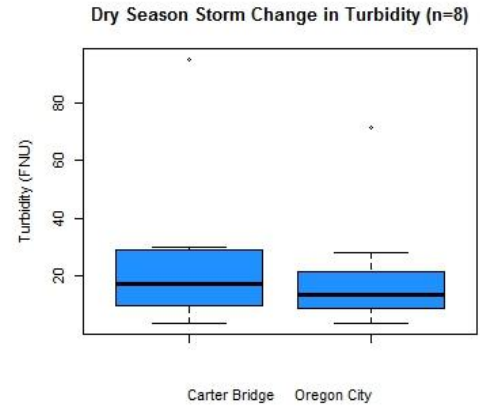

Figure 17. Boxplots of (a) minimum, (b) peak, and (c) change in turbidity during storm events 


\section{Discussion}

Based on the method of calculating a hysteresis index $(\mathrm{HI})$ at the midpoint of the hysteresis loop detailed by Lawler (2006) used in this analysis, overall, the majority of the storm events analyzed in this study exhibited a clockwise hysteresis pattern. This method was carefully selected for this study because of the importance of hysteresis as one of the many mechanisms that influences runoff during storm events. In comparison to the method of characterizing the properties of sediment discharge loops as detailed by other studies such as Seeger and others 2004 or Williams G. 1989, this method quantifies the magnitude and direction of the hysteretic affect in a single number and was used initially devised to be used with turbidity. Turbidity is a recognized surrogate for estimating suspended sediment concentrations and using an $\mathrm{HI}$ was better suited for this study than hysteretic loops.

Hysteresis is a rate-dependent non-linearity that is expressed through thresholds, switches and branches (Kane and Flynn, 2007). It is well established that soil moisture and precipitation are two of the primary influencing factors generating storm runoff. Subsequently soil moisture can be considered one of the critical switches that initiates storm runoff which further demonstrates the significance of taking hysteresis into account when investigating storm events. 


\subsection{Relation between land cover and hysteresis patterns}

Many studies have investigated hysteresis effects in relation to turbidity and suspended sediment concentrations during storm events (Istok and Boesrma, 1986; House and Warwick, 1998; Sheeder and Ross, 2002; Chang and Carlson 2004; Eder et al., 2010; Gellis 2013; Dominic et al. 2015; Zhang et al. 2016). Seeger et al. (2004) investigated discharge and suspended sediment concentrations during storms in a small headwater catchment in the Spanish Pyrenees. They determined that clockwise hysteresis in mountain catchments can be explained by the rapid displacement of sediment from sources near the channel and the decrease of sediment before the decrease in discharge indicates that the sediment sources are limited and rapidly depleted. This is also a likely explanation for the majority clockwise hysteresis observed at Carter Bridge which has a mostly forested upstream landscape.

During counter-clockwise HI events sediment sources are widespread throughout the catchment and not exhausted rapidly (Seeger et al., 2004). Lawler et al. (2006) conducted their study in an urban river in the United Kingdom and found counterclockwise hysteresis to be the dominant pattern in their urban setting. They suggested that counter-clockwise hysteresis could be explained by sources of suspended solids being further away from monitoring stations and also to the complex drainage systems present in urban environments in comparison to forested and rural settings. In situations where delayed sub-surface runoff is important, stream water is expected to 
be initially diluted in some solutes during storm runoff and be followed by higher concentrations when the sub-surface components becomes and important contributor (House and Warwick, 1997). The Oregon City monitoring station is located further downstream and its water-quality is impacted by a complicated network of upstream forested, agricultural and urban runoff sources. The higher number of counterclockwise hysteresis events at Oregon City in comparison to Carter Bridge may be attributed to the combined agricultural and urbanization signature due to its downstream location and tributaries that drain urban and suburban areas that have more complex landscapes in comparison to the forested upstream location of the Carter Bridge .

Increased turbidity during storm events is largely influenced by eroded sediment particles entering the stream from the near stream zone and upstream tributaries in the basin. Soil erosion and subsequent sediment transport into a waterway involves detachment, entrainment and eventual transport of particles via the stream network. In comparison to Carter Bridge, Oregon City has additional inputs from tributaries in the lower basin with the upstream influences of agricultural and urban development. This difference in tributary inputs must be taken into account when comparing turbidity measured during storms between the two stations. Agricultural practices affect the quantity of runoff through alteration of evaporation, the timing of runoff through changes in land drainage and water quality through erosion. Hydrologic consequences include siltation of water courses and reservoirs and an increase in flood peaks and a 
reduction in river low flows as vegetation and soil are removed from hill lands (Pimintel, 1976). As land urbanizes, it is covered by impervious surfaces and paved roads, parking lots, and roofs which prevent rainfall or snowmelt from infiltrating into the ground. Surface runoff in urban areas has a higher velocity than in nonurban areas because imperious surfaces are smoother than meadow, range land, forest or farm fields (Urbonas and Roesner, 1993). Once runoff starts, the quantity and size of material transported increases with the velocity of water runoff (Barfield and Warner, 1981). Particles transported in urban areas to rivers and streams contribute to increased turbidity during storm events. The larger tributaries in the northern part of the lower Clackamas Basin include Deep, Rock, and Sieben Creeks (Figure 1) contribute to runoff into the Clackamas River and runoff from this portion of the basin are not measured upstream at Carter Bridge.

Rock and Sieben Creeks drainage area (Figure 1) is roughly about $25 \mathrm{~km}^{2}$. In contrast to areas upstream of Carter Bridge ( $>88 \%$ forested) is classified as $33 \%$ forested (USGS, StreamStats) and the rest of this sub-basin is classified as $28 \%$ agriculture (cultivated crops), and the remaining portion of the land cover is classified as developed from low to high intensity. Storm water runoff from impervious surface area (12.4\%) originating from the urbanized lower basin would be likely to account for some of the differences in turbidity observed during storm events in comparison to upstream at Carter Bridge. 


\subsection{Effects of discharge on changes in turbidity}

Multiple linear regression (MLR) is an effective tool that can be used to explain the variation in a dependent variable (y), by using one or more explanatory variables. Antecedent precipitation index (API) of 3, 5, 7, 14 and 30 days, total precipitation (P) and change in discharge were the explanatory variables used to determine which one (or combination) of these variables best explained the change in turbidity during storms. It is well documented in literature that soil moisture conditions and precipitation are primary determinants in runoff during storm events (Nikas, 2007; Bousfield, 2008; Shakir, 2010; Tramblay, 2012). Results from MLR indicated that the model using change in discharge $[\Delta \mathrm{Q}=$ Natural $\log (\mathrm{Ln})$ of change in discharge] during a storm-event best explains the magnitude of turbidity during storms. The model developed for Carter Bridge and Oregon City using the log value of the change in discharge explained $81 \%$ of the change in turbidity at Carter Bridge and $48 \%$ of the change in turbidity for Oregon City during the 41-storm events selected for this study.

Results of MLR model surprisingly did not show any of the API indices to be one of the variables that contributed to the "best fit" results. In a few studies where API was the explanatory variable for runoff amounts (Fedor and Bescht, 1989)-API were directly related to storm runoff], (Nikas et al., 2007), found a correlation between API and runoff 
volume, (Ali et Al., 2010)-All found correlations with rainfall runoff amounts. ---This correlation did not translate to API in looking at changes in turbidity in this investigation. Onderka (2012) suggests that "complex systems (e.g. catchments) are most often hindered by interfering responses caused by several sub-processes that interact in time and space. It is very possible that the log "change in discharge" variable incorporates the processes of API and total precipitation and when the variables are regressed in the equations the "change in Q" variable overshadows the individual effect of API's and total precipitation. There is a correlation between the explanatory variables selected and it is a possible explanation as to why neither of the individual API's or precipitationtotal did not individually have representative coefficients in the final model equations.

\subsection{Implications for water management and potential model improvement}

The Oregon City site, located in the lower portion of the Clackamas Basin, is more impacted by upstream agriculture and urban development, and based on calculated $\mathrm{HI}$ values, it had more than three-times more likely to have counter clockwise hysteresis, with higher turbidity on the falling limb of the storm hydrograph than the upstream primarily forested Carter Bridge site. This information can be very important for water management agencies and drinking water providers in the basin. Knowing that a system is likely to have increased particulate matter (higher turbidity) on the recession limb of a hydrograph could inform management strategies in three ways that 
could lessen exposure to pollutants that are higher during storm runoff events, minimize costs for water treatment and provide real-time warnings of conditions that might prove detrimental to source-water quality and therefore the quality of finished water for drinking water providers that use water from the Clackamas River. High turbidity conditions can be detrimental to water treatment, and such conditions may be avoided with sufficient flexibility in planning, system storage, and operations.

The Clackamas Basin encompasses an area of $2,440 \mathrm{~km}^{2}$ of forested and rural land in the upper basin; with some agricultural and urban land in the lower basin. Studies have shown that the lack of spatially and temporally distributed rainfall data can have a serious impact on watershed runoff generation (Sun and others, 2002). Several factors must be considered attempting to understand the hydrological control that affect storm events in the basin. Precipitation is not uniformly distributed over the entire basin during storm events, therefore including spatially-varying precipitation amounts in different locations within the basin should improve our model results. 


\section{Summary and Conclusions}

\subsection{Summary}

This research answers the three questions stated in the introduction:

- In respect to the first research question:

"Are there any differences in turbidity measured during high-flow storm events between the Carter Bridge (upstream) and Oregon City (downstream) water-quality monitoring stations on the Clackamas River?"

Paired -t-tests results showed, of the 41 storm-events compared, turbidity values during storms between the two sites were statistically different. This is strong evidence that the two stations respond differently during storm events.

- In respect to the second research question

"What are the dominant hysteresis regimes in both stations by season?"

$\mathrm{HI}$ results showed that clockwise hysteresis $(\mathrm{C})$ was the most common pattern of $\mathrm{HI}$ at both sites, and Oregon City was "3-times" more likely to exhibit counter-clockwise (CC) hysteresis in comparison to Carter Bridge. The likely reason for this is that (C) hysteresis during storm events is due to turbidity peaks proceeding peaks in discharge and likely caused by depletion of sediments deposited in channels or near stream areas. The opposite CC is likely due to more complex particles introduced from complex urban 
environments and agricultural environments and by later arriving sediments from subbasins located in the lower portion of the Clackamas Basin.

- In respect to the third research question:

"Of the following parameters: antecedent precipitation index (API), total precipitation and discharge and which one, or combination of these parameters are the major controls that determine the magnitude of turbidity measured during storm events turbidity during storm events?" MLR model showed that the "Log change in discharge" best explained the "change in turbidity". A number of the model equations generated by the MLR did have coefficients for API values, but they were negative coefficients and not used in the final model. The log value of the change in discharge explains approximately $81 \%$ of the change in turbidity at Carter Bridge and $48 \%$ of the change in turbidity at Oregon City.

\section{Conclusions}

Storm events in the Clackamas Basin for purposes of the study particulate matter resulting increased turbidity (which can be attributed to sediment in the water column) are limited to sediment and other particles near the stream channel. Similar conclusions suggested that observed hysteresis might be due to early episode flushing of soluble material (Walling and Foster, 1975), McKee et. al. (2000) attributed nutrient 
concentrations during storm events to similar hysteresis patterns by the flushing of material on the rising limb of a hydrograph during storms.

\subsection{Suggested Additional Research}

Further investigation into the research questions would likely focus on having concurrent suspended sediment concentration and particle size analysis. With this additional information it would be possible to establish a correlation and measurable relationship between the turbidity and suspended sediment concentration. Additional sample collection and turbidity measurement in the lower basin would also give information about the differences in particles mobilized during events between the forested upstream flow regimes and the more mixed land-use flow regimes.

It would also be beneficial to obtain discharge measurements at Carter Bridge instead of using discharge measurements from the upstream Three Lynx station as a surrogate for discharge at Carter Bridge. 


\section{References}

Ali S., Ghosh N. and Singh R., 2010, Rainfall-runoff simulation using a normalized antecedent precipitation index, Hydrological Sciences Journal, 55:2, 266-274

American Public Health Association, American Water Works Association, and Water

Environment Federation. 1998. Standard methods for the examination of water and wastewaters (20 $2{ }^{\text {th }}$ Ed.). American Public Health Association, Washington, D.C., pp. 2-8 to 2-11.

Anderson, C.W., and Rounds, S.A., 2003, Phosphorus and E. coli and their relation to selected constituents during storm runoff conditions in Fanno Creek, Oregon, 1998-99: U.S. geological Survey Water-Resources Investigations Report 02-4232, 34 p.

Anderson C.W., 2006, Turbidity (ver. 2.1): U.S. Geological Survey Techniques of WaterResources Investigations, book 9, chap. A6., sec. 6.7, September, 2005 accessed [March 30, 2014], from http://pubs.water.usgs.gov/twri9A6/.

ASTM International, 2003a, D1889-00 Standard test method for turbidity of water, in ASTM International, Annual Book of ASTM Standards, Water and Environmental Technology, 2003, v. 11.01, West Conshohocken, Pennsylvania, 6 p.

Barfield B., Warner R., 1981, Applied Hydrology and sedimentation for disturbed areas, Berrie, A. D., 1993, The rivers handbook volume 1: Hydrological and ecological principles, edited by P. Calow and G. E. Petts, Blackwell Scientific Publications, Oxford. $526 \mathrm{pp}$.

Bragg H., Sobieszczyk, S., Uhrich, M., and Piatt D., 2007, Suspended-sediment loads and yields in the North Santiam river basin, Oregon, water years 1999-2004: U.S. Geological Survey Scientific Investigations Report 2007-5187, 26 p.

Calder I., 1993, Hydrologic Effects of Land Use Change section 13.1, published in Handbook of hydrology David Maidment Editor McGraw-Hill Inc.

Cannon A., Whitfield P., 2001 Modeling Transient pH Depressions in Coastal Streams of British Columbia using Neural Networks Journal of the American Water Resources Association Volume 37, 1, 73-89

Carpenter K., 2003, Water Quality and Algal Conditions in the Clackamas River Basin, Oregon and their Relations to Land and Water Management, U.S. Geological Survey WRIR 02-4189

Chang H., 2007, Comparative stream flow characteristics in urbanizing basins in the Portland Metropolitan Area, Oregon, USA, Hydrological Processes 21, 211-222 
Chanson H., Takeuchi M., Trevethan M., 2008 Using turbidity and acoustic backscatter intensity as surrogate measures of suspended sediment concentration in a small subtropical estuary. Journal of Environmental Management 88, 1406-1416

Chen H., Chang, H., 2014 Response of Discharge, TSS, and E.coli to Rainfall Events in Urban, Suburban, and Rural Watersheds. Environmental Science: Processes and Impacts 16 (10): $2313-2324$

Clackamas River Water Providers Website, 2017, http://www.clackamasproviders.org/crwp-members/ accessed 3/1/2017

Davie T., 2008, Fundamentals of Hydrology, $2^{\text {nd }}$ ed., pg. 132, by Routledge Taylor and Francis Group

Davies-Colley, R.J., and Smith, D.G., 2001, Turbidity, suspended sediment, and water clarity-A review: Journal of the American Water Resources Association, v. 37, no. 5, p. 1085-1101.

Driver, N. E., Troutman B.M., 1988, Regression Models for Estimating Urban StormRunoff Quality and Quantity in the United States Journal of Hydrology, 109 (1989) 221236221 Elsevier Science Publishers B.V., Amsterdam -- Printed in The Netherlands

Eckhardt K., 2008, A comparison of baseflow indices, which were calculated with seven different baseflow separation methods, Journal of Hydrology 352, 168-173

Esralew, R.A., Andrews, W.J., and Smith, S.J., 2011, Evaluation and trends of land cover, stream flow, and water quality in the North Canadian River Basin near Oklahoma City, Oklahoma, 1968-2009: U.S. Geological Survey Scientific Investigations Report 20115117, 97 p. (Revised October 2011)

Evans, C. and Davies, T.D., 1998, Causes of concentration/discharge hysteresis and its potential as a tool for analysis of episode hydrochemistry, Journal of the American Water Resources Association 38 (4):1027-1040.Fausch, Kurt D.; Torgersen, Christian E.;

Fedora M.A. and Beschta R.L., 1989, Storm Runoff Simulation using an Antecedent Precipitation Index (API) Model, Journal of Hydrology, 112, 121-133 Elsevier Science Publishers B.V., Amsterdam- Printed in The Netherlands

Fletcher T.D. and Deletic, 2007 Statistical evaluation and optimization of storm water quality monitoring programs Water Science \& Technology Vol 56 No 12 pp 1-9 Q

Foster I., 1978, a Multivariate Model of Storm-Period Solute Behaviour. Journal of Hydrology, 39, 339-353 Elsevier Science Publishers B.V., Amsterdam-Printed in the Netherlands

Gering A.J., 1985, Soil Survey of Clackamas County Oregon, United States Department of Agriculture, Soil Conservation Service in cooperation with United States Department of Interior, Bureau of Land Management and Oregon Agricultural Experiment Station 
Gippel, C., 1989, Use of turbidimeters in suspended sediment research: Hydrobiologia, v. 176 , no 17, p. $74-76$

Gippel, C. 1995, Potential of turbidity monitoring for measuring the transport of suspended solids in streams, Hydrol. Processes, 9, 83-97

Graves D., and Chang H., 2007, Clim Res. Vol. 33: 143-157

Gray J., and Glysson D., 2003, Proceedings of the federal interagency workshop on turbidity and other sediment surrogates, April30-May 2, 2002, Reno, Nevada: U.S. Geological Survey Circular 1250, 56 p.

Helsel D.R., and Hirsch Statistical Methods in Water Resources, 2002, Techniques of Water-Resources Investigations of the United States Geological Survey Book 4, Hydrologic Analysis and Interpretation Chapter A3, Publication available at: http://water.usgs.gov/pubs/twri/twri4a3/ Horowitz, A., 1991 A primer on sediment-trace element chemistry $2^{\text {nd }}$ rev.ed. by Lewis Publishers, Inc.

Homer, C.H., Fry, J.A., and Barnes C.A., 2012, The National Land Cover Database, U.S. Geological Survey Fact Sheet 2012-3020, 4 p. (https://www.mrlc.gov/nlcd11 data.php) House, William A., and Warwick Melanie S., 1998, Hysteresis of the solute concentration/discharge relationship in rivers during storms. Water Res earch, 32(8): $2279-2290$

International Organization for Standardization, Reference number ISO 7027:1999(E) 1999, International Standard ISO 7027 was prepared by Technical Committee ISO/TC 147, Water quality, Subcommittee SC 2, Physical, chemical, biochemical methods.

Istok J., Boersma L., 1986 Journal of Hydrology, 88, 329-342 Elsevier Science Publishers B.V., Amsterdam -- Printed in the Netherlands

Langan S., and Hirst D., 2004, An analysis of the long-term variation in stream water quality for three upland catchments at Loch Dee (Galloway, S.W. Scotland) under contrasting land management, Hydrology and Earth Systems Sciences, 8 (3), 422-435 Larson, S., Capel P., Majewski M., 1997 Pesticides in surface waters: distribution, trends, and governing factors, Volume Three of the Series Pesticides in the Hydrologic System Ann Arbor Press, Inc.

Lawler D., Petts G., Foster I., Harper S., 2006, Turbidity dynamics during storm events in an urban headwater river system: The Upper Tame, West Midlands, UK Science of the Total Environment 360, 109-126

McCutcheon S., Martin J., Barnwell T., 1993, Water Quality section 11.1.5, published in Handbook of hydrology David Maidment Editor McGraw-Hill Inc. 
McKee L., Bradley E., Shahadat H., 2000, Intra- and interannual export of nitrogen and phosphorus in the subtropical Richmond River catchment, Australia, Hydrol. Process 14, 1787-1809,

Meene. J., Williams C. and Vose R., 2013. United States Historical Climatology Network Daily Temperature, Precipitation, and Snow Data. Carbon Dioxide Information Analysis Center, Oak Ridge National Laboratory, Oak Ridge, Tennessee. Available on-line: (http://cdiac.ornl.gov/epubs/ndp/ushcn/ushcn.html) from the Carbon Dioxide Information Analysis Center, Oak Ridge National Laboratory, Oak Ridge, Tennessee.

Metro, 1997, Clackamas River Watershed Atlas: Portland, Oregon, Metro Regional Services, $41 \mathrm{p}$.

Meybeck M. and Moatar F., 2012, Daily variability of river concentrations and fluxes: indicators based on segmentation of the rating curve, Hydrological Processes 26, 11881207

Nikas K., Antonakos A., Lambrakis N., and Kallergis G., 2007, THE USE OF ANTECEDENT PRECIPITATION INDEX AND "DELAY FACTOR" TO ESTIMATE RUNOFF FROM RAINFALL; A CASE STUDY FROM EIGHT DRAINAGE BASINS -ACHAIA, PELOPONESSOS, GREECE., Bulletin of the Geological Society of Greece vol. XXXX, 2007 Proceedings of the 11 th International Congress, Athens, May

Onderka M., Andreas K., Wrede S., Martínez-Carreras N., Hoffmann L., 2012, Dynamics of storm-driven suspended sediments in a headwater catchment described by multivariable modeling- J Soils Sediments 12:620-635--Reference for antecedent conditions and table showing storm events

Pidwirny, M., 2006, Climate Classification and Climatic Regions of the World". Fundamentals of Physical Geography, 2nd Edition

Prestigiacomo A., Steven E., O'Donnell D., Hassett J., Michalenko E., Lee Z., and Weidemann A., 2007, Turbidity and suspended solids levels and loads in a sediment enriched stream: implications for impacted lotic and lentic ecosystems, Lake and Reservoir Management, 23:3, 231-244

Rantz, S, 1982, Measurement and computation of stream flow (Geological Survey Water-Supply Paper 2175) Includes bibliographies. Contents: v. 1. Measurement of stage and discharge.- v. 2. Computation of discharge. 1. Stream measurements.

Rasmussen, T., Lee, C., and Ziegler, A., 2008, Estimation of constituent concentrations, loads, and yields in streams of Johnson County, northeast Kan sas, using continuous water-quality monitoring and regression models, October 2002 through December 2006: U.S. Geological Survey Scientific Investigations Report 2008-5014, 103 p. 
Rutledge A.T., 1993 Computer programs for describing the recession of ground-water discharge and for estimating mean ground-water recharge and discharge from streamflow records U.S. Geological Survey Water Resource Investigations Report 93$412145 \mathrm{p}$.

Settle S., Ashantha G., and Godwin A., 2007, Determination of Surrogate Indicators for Phosphorus and Solids in Urban Storm water: Application of Multivariate Data Analysis Techniques Water Air Soil Pollution 182:149-161

Sadar M., 1999, Turbidimeter Instrument Comparison: Low-level Sample Measurements. Hach Company, all rights reserved Printed in U.S.A. D90.5

Seeger M., Erreab M., Beguerı'ab S., Arna'ezc J., Martı'b C., Garci'a-Ruiz J., 2004 Catchment soil moisture and rainfall characteristics as determinant factors for discharge/suspended sediment hystereticloops in a small headwater catchment in the Spanish Pyrenees., Journal of Hydrology 288, 299-311

http://www.elsevier.com/locate/jhydrol

Shedder, S., Ross J., and Carlson T., 2002, Dual urban and rural hydrograph signals in three small watersheds. Journal of the American Water Resources Association 38 (4):1027-1040

Sun H., Cornish P.S., Daniel T.M., 2002, Spatial Variability in Hydrologic Modeling Using Rainfall-Runoff Model and Digital Elevation Model, , J. Hydrol. Eng. 7:404-412

Taylor B., 1999, Salmon and Steelhead Runs and Related Events of the Clackamas River Basin-A Historical Perspective, Prepared for Portland General Electric (PGE). for copies contact: PGE Hydro Licensing Department 121 SW Salmon St. Portland, OR 97204

Tramblay Y., Bouaicha R., Brocca L., Dorigo W., Camici S., Servat E., 2012, Estimation of antecedent wetness conditions for flood modelling in northern Morocco, Hydrology and Earth System Sciences, 16, 4375-4386

Uhrich, M., Bragg H., 2003, Monitoring in stream turbidity to estimate continuous suspended-sediment loads and yields and clay-water volumes in the Upper Santiam River Basin, Oregon, 1998-2000: U.S. Geological Survey Water-Resources Investigations Report 03-4098, 43 p.

Uhrich, M., Kolasinac J., Booth P., Fountain L., Spicer K., and Mosbrucker R.,2014, Correlations of Turbidity to Suspended-Sediment Concentration in the Toutle River Basin, near Mount St. Helens, Washington, 2010-11, 2014, Geological Survey Open-File Report 2014-1204, 30 p.,

Urbonas B., Roesner L., 1993, Hydrologic Design for Urban Drainage and Flood Control, published in Handbook of hydrology David Maidment Editor McGraw-Hill Inc.

U.S. Geological Survey, 2016, The StreamStats program, online at http://streamstats.usgs.gov, accessed on (4/13/2017). 
Van Dijk A., 2010, Climate and terrain factors explaining stream flow response and recession in Australian catchments. Hydrol. Earth Syst. Sci., 14, 159-169

Verzani J., 2004, Using R for introductory statistics, CRC Press Taylor and Francis Group, LLC

Vicenzo, A., Molino, B., Viparelli R., Caramiscia P., 2011A methodological approach for estimating turbidity in a river, International Journal of Sediment Research 26, 112-119

Wagner, R., Boulger, R., Jr., Oblinger, C., Smith, B., 2006, Guidelines and standard procedures for continuous water-quality monitors-Station operation, record computation, and data reporting: U.S. Geological Survey Techniques and Methods, Book 1, Chapter D3.

Walling, D., Foster I., 1975, Variations in natural chemical concentration of river water during flood flows, and the lag effect: Some further comments, J. Hydrol.,26, 237-244, Walling, D., Webb B., 1998, the reliability of rating curve estimates of suspended sediment yield: some further comments, in Sediment Budgets, IAHS Publ.174, pp. 337350

Ward A., Trimble S., 2004, Environmental Hydrology Second Edition pg. 59, CRC Press LLC, Lewis Publishers

Wass P., Marks S., Finch J., Leeks G., Ingram J., (1997) Monitoring and preliminary interpretation of in-river turbidity and remote sensed imagery for suspended sediment transport studies in the Humber catchment. The Science of the Total Environment 194/195 263-283

Williams G., 1989, J Suspended Sediment Concentration vs. Discharge during Single Hydrologic Events in Rivers, Journal of Hydrology, 111, 89-106 89. Elsevier Science Publishers B.V.,Amsterdam printed in Netherlands

Yellow Springs Incorporated (YSI) Incorporated Environmental Monitoring Systems Manual pg. 5-18, Item \#069300 Revision E April, 2009 


\section{Appendix A-Statistical Summary of Turbidity and Discharge Data for Clackamas at Carter Bridge and Oregon City Sites}

Turbidity Data Water Years 2006-2012 Discharge Data Water Years 2006-2012

\begin{tabular}{|c|c|c|c|c|c|}
\hline Statistic & $\begin{array}{c}\text { Carter } \\
\text { Bridge } \\
\text { (FNU) }\end{array}$ & $\begin{array}{c}\text { Oregon } \\
\text { City } \\
\text { (FNU) }\end{array}$ & Statistic & $\begin{array}{c}\text { Carter } \\
\text { Bridge } \\
\text { (Three } \\
\text { Lynx) } \\
\text { (CMS) }\end{array}$ & $\begin{array}{c}\text { Oregon } \\
\text { City } \\
\text { (CMS) }\end{array}$ \\
\hline Mean & 5.1 & 4.5 & Mean & 70.6 & 106.3 \\
\hline $\begin{array}{l}\text { Standard } \\
\text { Deviation }\end{array}$ & 18.5 & 14.2 & $\begin{array}{l}\text { Standard } \\
\text { Deviation }\end{array}$ & 62.2 & 111.0 \\
\hline IQR & 2.7 & 2.7 & IQR & 59.1 & 101.0 \\
\hline Minimum & 0 & 0 & Minimum & 18.3 & 21.1 \\
\hline $25 \%$ & 0.7 & 0.7 & $25 \%$ & 29.0 & 32.3 \\
\hline Median & 1.5 & 1.4 & Median & 55.4 & 81.3 \\
\hline $75 \%$ & 3.4 & 3.4 & $75 \%$ & 88.1 & 133.2 \\
\hline Maximum & 340 & 340 & Maximum & 674.2 & 1413.0 \\
\hline$n$ & 2509 & 2535 & $n$ & 2557 & 2454 \\
\hline $\begin{array}{l}\text { Missing } \\
\text { Values }\end{array}$ & 48 & 22 & $\begin{array}{l}\text { Missing } \\
\text { Values }\end{array}$ & 0 & 103 \\
\hline
\end{tabular}

$\mathrm{FNU}=$ formazin nephelometric units, $\mathrm{CMS}=$ cubic meters per second, IQR=interquartile range 
Appendix B-Annual Precipitation Data Summary Measured at Clackamas at Three Lynx for Water Years 2006-2012

\begin{tabular}{|l|l|l|l|l|l|l|l|l|l|}
\hline Month & $\begin{array}{l}\text { Water } \\
\text { Year } \\
\mathbf{2 0 0 6} \\
(\mathbf{m m})\end{array}$ & $\begin{array}{l}\text { Water } \\
\text { Year } \\
\mathbf{2 0 0 7} \\
(\mathbf{m m})\end{array}$ & $\begin{array}{l}\text { Water } \\
\text { Year } \\
\mathbf{2 0 0 8} \\
(\mathbf{m m})\end{array}$ & $\begin{array}{l}\text { Water } \\
\text { Year } \\
\mathbf{2 0 0 9} \\
(\mathbf{m m})\end{array}$ & $\begin{array}{l}\text { Water } \\
\text { Year } \\
\mathbf{2 0 1 0} \\
(\mathbf{m m})\end{array}$ & $\begin{array}{l}\text { Water } \\
\text { Year } \\
\mathbf{2 0 1 1} \\
(\mathbf{m m})\end{array}$ & $\begin{array}{l}\text { Water } \\
\text { Year } \\
\mathbf{2 0 1 2} \\
(\mathbf{m m})\end{array}$ & $\begin{array}{l}\text { Monthly } \\
\text { Average } \\
(\mathbf{m m})\end{array}$ & $\begin{array}{l}\text { Standard } \\
\text { Deviatio } \\
\mathbf{n}\end{array}$ \\
\hline October & 142.2 & 639.1 & 188.0 & 228.3 & 269.2 & 292.1 & 233.4 & 284.6 & 164.7 \\
\hline November & 303.3 & 299.5 & 382.8 & 241 & 186.7 & 357.1 & 211.3 & 283.1 & 73.4 \\
\hline December & 356.4 & 166.9 & 280.2 & 197.6 & 213.1 & 207.3 & 424.9 & 263.8 & 95.2 \\
\hline January & 475 & 270 & 162.1 & 181.9 & 128.5 & 199.4 & 210.1 & 232.4 & 115.6 \\
\hline February & 139.2 & 108.5 & 190 & 229.1 & 241.3 & 243.8 & 393.2 & 220.7 & 92.2 \\
\hline March & 144.3 & 104.4 & 151.6 & 165.9 & 177.5 & 257.3 & 176.8 & 168.3 & 46.6 \\
\hline April & 130.3 & 49.8 & 109 & 159.3 & 16.3 & 131.6 & 101.6 & 99.7 & 36.3 \\
\hline May & 68.3 & 48.5 & 66.3 & 51.3 & 164.6 & 50.5 & 145 & 84.9 & 48.7 \\
\hline June & 1.0 & 8.4 & 2.3 & 8.9 & 13.2 & 29.7 & 10.4 & 10.6 & 9.5 \\
\hline July & 6.1 & 27.7 & 62.5 & 6.9 & 0.0 & 4.6 & 0.3 & 15.4 & 22.8 \\
\hline August & 35.3 & 65.5 & 28.7 & 45.5 & 106.4 & 9.1 & 1.8 & 41.8 & 35.7 \\
\hline September & 100.6 & 172 & 90.2 & 195.1 & 153.4 & 114.3 & 232.2 & 151.1 & 52.5 \\
\hline mamillim & & & & & & & & & \\
\hline
\end{tabular}

$\mathrm{m}=$ millimeters 
Appendix C Annual Precipitation Data Summary at Three Lynx and Oregon City for years 2006-2012

\begin{tabular}{|l|r|r|}
\hline \multicolumn{2}{|l|}{$\begin{array}{l}\text { Yater } \\
\text { Year 2006 }\end{array}$} & \multicolumn{2}{|l|}{} \\
\hline Statistic & \multicolumn{2}{|l|}{ Three Lynx } \\
Mean & 5.2 & 3.2 \\
\hline $\begin{array}{l}\text { Standard } \\
\text { Deviation }\end{array}$ & 10.3 & 7.5 \\
\hline IQR & 5.1 & 1.8 \\
\hline $0 \%$ & 0.0 & 0.0 \\
\hline $25 \%$ & 0.0 & 0.0 \\
\hline $50 \%$ & 0.0 & 0.0 \\
\hline $75 \%$ & 5.1 & 1.8 \\
\hline $100 \%$ & 71.1 & 50.8 \\
\hline $\mathrm{n}$ & 365 & 320 \\
\hline Missing & 0 & 45 \\
\hline
\end{tabular}

\begin{tabular}{|c|c|c|}
\hline \begin{tabular}{|l} 
Water \\
Year 2007
\end{tabular} & & \\
\hline Statistic & Three & Oregon City \\
\hline Mean & 5.4 & 1.6 \\
\hline $\begin{array}{l}\text { Standard } \\
\text { deviation }\end{array}$ & 11.2 & 4.9 \\
\hline IQR & 5.3 & 0.8 \\
\hline $0 \%$ & 0.0 & 0.0 \\
\hline $25 \%$ & 0.0 & 0.0 \\
\hline $50 \%$ & 0.0 & 0.0 \\
\hline $75 \%$ & 5.3 & 0.8 \\
\hline $100 \%$ & 102.4 & 50.8 \\
\hline$n$ & 365 & 341 \\
\hline Missing & 0 & 24 \\
\hline
\end{tabular}


Annual Precipitation Data Summary at Three Lynx and Oregon City for years 20062012 (cont.)

\begin{tabular}{|c|c|c|}
\hline $\begin{array}{l}\text { Water } \\
\text { Year } 2008\end{array}$ & & \\
\hline Statistic & Three Lynx & $\begin{array}{l}\text { Oregon } \\
\text { City }\end{array}$ \\
\hline Mean & 4.7 & 3.2 \\
\hline $\begin{array}{l}\text { Standard } \\
\text { Deviation }\end{array}$ & 8.2 & 7.7 \\
\hline IQR & 6.8 & 1.8 \\
\hline $0 \%$ & 0.0 & 0.0 \\
\hline $25 \%$ & 0.0 & 0.0 \\
\hline $50 \%$ & 0.1 & 0.0 \\
\hline $75 \%$ & 6.8 & 1.8 \\
\hline $100 \%$ & 47.0 & 50.8 \\
\hline $\mathrm{n}$ & 270 & 366 \\
\hline Missing & 96 & 0 \\
\hline
\end{tabular}

\begin{tabular}{|l|r|r|}
\hline \multicolumn{1}{|l|}{$\begin{array}{l}\text { Yater } \\
\text { Year 2009 }\end{array}$} & \multicolumn{2}{|c|}{$\begin{array}{c}\text { Oregon } \\
\text { City }\end{array}$} \\
\hline Mean & 4.7 & 2.2 \\
\hline $\begin{array}{l}\text { Standard } \\
\text { Deviation }\end{array}$ & 9.4 & 6.2 \\
\hline IQR & 5.1 & 1.3 \\
\hline $0 \%$ & 0.0 & 0.0 \\
\hline $25 \%$ & 0.0 & 0.0 \\
\hline $50 \%$ & 0.0 & 0.0 \\
\hline $75 \%$ & 5.1 & 1.3 \\
\hline $100 \%$ & 64.8 & 63.5 \\
\hline $\mathrm{n}$ & 365 & 327 \\
\hline Missing & 0 & 38 \\
\hline
\end{tabular}


Annual Precipitation Data Summary at Three Lynx and Oregon City for years 20062012

\begin{tabular}{|l|r|r|}
\hline $\begin{array}{l}\text { Yater } \\
\text { Year 2010 }\end{array}$ & \multicolumn{2}{|l}{} \\
\hline Statistic & \multicolumn{2}{|l|}{ Three Lynx } \\
Cregon \\
\hline Mean & 4.9 & 3.1 \\
\hline $\begin{array}{l}\text { Standard } \\
\text { Deviation }\end{array}$ & 8.8 & 6.5 \\
\hline IQR & 6.4 & 2.5 \\
\hline $0 \%$ & 0.0 & 0.0 \\
\hline $25 \%$ & 0.0 & 0.0 \\
\hline $50 \%$ & 6.3 & 0.0 \\
\hline $75 \%$ & 49.5 & 2.5 \\
\hline $100 \%$ & 365 & 39.5 \\
\hline $\mathrm{n}$ & 0 & 3 \\
\hline Missing & & \\
\hline
\end{tabular}

\begin{tabular}{|l|r|r|}
\hline $\begin{array}{l}\text { Yater } \\
\text { Year 2011 }\end{array}$ & \multicolumn{2}{|l|}{} \\
\hline Statistic & Three Lynx & \multicolumn{2}{|l|}{$\begin{array}{l}\text { Cregon } \\
\text { Mean }\end{array}$} & 5.2 & 3.9 \\
\hline $\begin{array}{l}\text { Standard } \\
\text { Deviation }\end{array}$ & 9.4 & 8.2 \\
\hline IQR & 6.9 & 4.1 \\
\hline $0 \%$ & 0.0 & 0.0 \\
\hline $25 \%$ & 0.0 & 0.0 \\
\hline $50 \%$ & 0.8 & 0.0 \\
\hline $75 \%$ & 6.9 & 4.1 \\
\hline $100 \%$ & 75.2 & 50.8 \\
\hline $\mathrm{n}$ & 365 & 365 \\
\hline Missing & 0 & 0 \\
\hline
\end{tabular}


Annual Precipitation Data Summary at Three Lynx and Oregon City for years 20062012

\begin{tabular}{|c|c|c|}
\hline $\begin{array}{l}\text { Water } \\
\text { Year } 2012\end{array}$ & & \\
\hline Statistic & Three Lynx & $\begin{array}{l}\text { Oregon } \\
\text { City }\end{array}$ \\
\hline Mean & 5.8 & 3.4 \\
\hline $\begin{array}{c}\text { Standard } \\
\text { Deviation }\end{array}$ & 12.3 & 8.1 \\
\hline IQR & 6.5 & 2.5 \\
\hline $0 \%$ & 0.0 & 0.0 \\
\hline $25 \%$ & 0.0 & 0.0 \\
\hline $50 \%$ & 0.0 & 0.0 \\
\hline $75 \%$ & 6.5 & 2.5 \\
\hline $100 \%$ & 120.7 & 58.2 \\
\hline$n$ & 366.0 & 366.0 \\
\hline Missing & 0 & 0 \\
\hline
\end{tabular}


Appendix D-Summary and Statistical Information of Wet Season and Dry Season Turbidity and Discharge

Wet Season (October-March)

Wet Season (October-March)

Turbidity Data 2006-2012

Discharge Data 2006-2012

\begin{tabular}{|c|c|c|c|c|c|}
\hline Statistic & $\begin{array}{l}\text { Carter } \\
\text { Bridge } \\
\text { (FNU) }\end{array}$ & $\begin{array}{l}\text { Oregon } \\
\text { City } \\
\text { (FNU) }\end{array}$ & Statistic & $\begin{array}{l}\text { Carter } \\
\text { Bridge } \\
\text { (Three } \\
\text { Lynx) } \\
\text { (CMS) }\end{array}$ & $\begin{array}{l}\text { Oregon } \\
\text { City } \\
\text { (CMS) }\end{array}$ \\
\hline Mean & 8.2 & 7.3 & Mean & 82.5 & 131.4 \\
\hline $\begin{array}{l}\text { Standard } \\
\text { Deviation }\end{array}$ & 22.6 & 19.5 & $\begin{array}{l}\text { Standard } \\
\text { Deviation }\end{array}$ & 74.4 & 134.5 \\
\hline IQR & 4.0 & 5 & IQR & 54.4 & 97.1 \\
\hline Minimum & 0 & 0 & Minimum & 21.8 & 22.0 \\
\hline $25 \%$ & 1.1 & 1 & $25 \%$ & 39.6 & 53.5 \\
\hline Median & 2.2 & 2.4 & Median & 62.6 & 92.6 \\
\hline $75 \%$ & 5.1 & 6 & $75 \%$ & 94.0 & 150.7 \\
\hline Maximum & 340 & 340 & Maximum & 674.2 & 1413.0 \\
\hline$n$ & 1254 & 1271 & $\mathrm{n}$ & 1276 & 1273 \\
\hline $\begin{array}{l}\text { Missing } \\
\text { Values }\end{array}$ & 22 & 5 & $\begin{array}{l}\text { Missing } \\
\text { Values }\end{array}$ & 0 & 3 \\
\hline
\end{tabular}


Dry Season (April-September)

Turbidity Data 2006-2012

\begin{tabular}{|c|c|c|c|c|c|}
\hline Statistic & $\begin{array}{l}\text { Carter } \\
\text { Bridge }\end{array}$ & $\begin{array}{l}\text { Oregon } \\
\text { City }\end{array}$ & Statistic & $\begin{array}{l}\text { Carter } \\
\text { Bridge } \\
\text { (Three } \\
\text { Lynx) }\end{array}$ & $\begin{array}{l}\text { Oregon } \\
\text { City }\end{array}$ \\
\hline Mean & 22.1 & 1.6 & Mean & 58.7 & 79.3 \\
\hline $\begin{array}{l}\text { Standard } \\
\text { Deviation }\end{array}$ & 22.9 & 2.1 & $\begin{array}{l}\text { Standard } \\
\text { Deviation }\end{array}$ & 45.4 .0 & 68.6 \\
\hline IQR & 26.0 & 1.1 & IQR & 58.0 & 86.9 \\
\hline Minimum & 1.0 & 0 & Minimum & 18.3 & 21.1 \\
\hline $25 \%$ & 7.0 & 0.6 & $25 \%$ & 26.8 & 27.2 \\
\hline Median & 11.0 & 0.9 & Median & 36.5 & 47.9 \\
\hline $75 \%$ & 33.0 & 1.7 & $75 \%$ & 84.9 & 114.1 \\
\hline Maximum & 96.0 & 26 & Maximum & 311.0 & 472.9 \\
\hline$n$ & 1281 & 1264 & $n$ & 1281 & 1181 \\
\hline $\begin{array}{l}\text { Missing } \\
\text { Values }\end{array}$ & 0 & 17 & $\begin{array}{l}\text { Missing } \\
\text { Values }\end{array}$ & & 100 \\
\hline
\end{tabular}

Dry Season (April-September)

Discharge Data 2006-2012

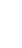




\section{Appendix E- Hysteresis Indices for Carter Bridge}

\begin{tabular}{|c|c|c|c|c|c|c|c|c|c|}
\hline \multicolumn{10}{|c|}{ Hysteresis Indices and Associated Data from Clackamas at Carter Bridge } \\
\hline $\begin{array}{l}\text { Event } \\
\text { ID }\end{array}$ & $\begin{array}{l}\text { WY } \\
2006 \\
\text { Dates }\end{array}$ & $\begin{array}{l}\text { Qmin } \\
\left(\mathrm{M}^{3} / \mathrm{sec}\right)\end{array}$ & $\begin{array}{l}\text { Qmax } \\
\left(\mathrm{M}^{3} / \mathrm{sec}\right)\end{array}$ & $\begin{array}{l}\text { Qmid } \\
\text { (M3/sec) }\end{array}$ & $\begin{array}{l}\text { Qrising } \\
\left(\mathrm{TU}_{\mathrm{RL}}\right)\end{array}$ & $\begin{array}{l}\text { Qfalling } \\
\left(\mathrm{TU}_{\mathrm{FL}}\right)\end{array}$ & Season & HI & HD \\
\hline 2006.1 & $\begin{array}{l}11 / 10- \\
11 / 24\end{array}$ & 41.1 & 85.8 & 63.4 & 14 & 1.6 & wet & 7.75 & C \\
\hline 2006.2 & $\begin{array}{l}12 / 18- \\
12 / 26\end{array}$ & 25.3 & 354.0 & 189.6 & 45 & 47 & wet & -0.04 & CC \\
\hline 2006.3 & $\begin{array}{l}12 / 29- \\
1 / 6\end{array}$ & 184.6 & 560.7 & 372.6 & 110 & 92 & wet & 0.20 & $C$ \\
\hline 2006.6 & $\begin{array}{l}1 / 28- \\
2 / 11\end{array}$ & 74.2 & 219.7 & 147.0 & 22 & 8.4 & wet & 1.62 & C \\
\hline 2006.7 & $\begin{array}{l}2 / 27- \\
3 / 5\end{array}$ & 45.9 & 62.6 & 54.2 & 3 & 0.3 & wet & 9.00 & C \\
\hline 2006.8 & $\begin{array}{l}3 / 7- \\
3 / 12\end{array}$ & 49.6 & 57.8 & 53.7 & 1.2 & 3.9 & wet & -2.25 & CC \\
\hline 2006.9 & $\begin{array}{l}4 / 2- \\
4 / 30\end{array}$ & 52.1 & 103.6 & 77.9 & 17 & 2.2 & dry & 6.73 & $C$ \\
\hline $\begin{array}{l}\text { Event } \\
\text { ID }\end{array}$ & $\begin{array}{l}\text { WY } \\
2007 \\
\text { Dates }\end{array}$ & $\begin{array}{l}\text { Qmin } \\
\left(\mathrm{M}^{3} / \mathrm{sec}\right)\end{array}$ & $\begin{array}{l}\text { Qmax } \\
\left(\mathrm{M}^{3} / \mathrm{sec}\right)\end{array}$ & $\begin{array}{l}\text { Qmid } \\
\text { (M3/sec) }\end{array}$ & $\begin{array}{l}\text { Qrising } \\
\left(\mathrm{TU}_{\mathrm{RL}}\right)\end{array}$ & $\begin{array}{l}\text { Qfalling } \\
\left(\mathrm{TU}_{\mathrm{FL}}\right)\end{array}$ & Season & HI & HD \\
\hline 2007.1 & $\begin{array}{l}10 / 31- \\
11 / 12\end{array}$ & 20.5 & 515.4 & 267.9 & 170 & 100 & wet & 0.70 & $C$ \\
\hline 2007.2 & $\begin{array}{l}12 / 8- \\
12 / 22\end{array}$ & 63.7 & 356.8 & 210.3 & 34 & 32 & wet & 0.06 & C \\
\hline 2007.3 & $\begin{array}{l}12 / 22- \\
1 / 7\end{array}$ & 84.1 & 253.2 & 168.6 & 29 & 12 & wet & 1.42 & C \\
\hline 2007.6 & $\begin{array}{l}3 / 24- \\
4 / 1\end{array}$ & 69.7 & 122.9 & 96.3 & 11 & 2.7 & wet & 3.07 & C \\
\hline $\begin{array}{l}\text { Event } \\
\text { ID }\end{array}$ & $\begin{array}{l}W Y \\
2008\end{array}$ & $\begin{array}{l}\operatorname{Qmin}_{\left(\mathrm{M}^{3} / \mathrm{sec}\right)} \\
\end{array}$ & $\begin{array}{l}\text { Qmax } \\
\left(\mathrm{M}^{3} / \mathrm{sec}\right)\end{array}$ & $\begin{array}{l}\text { Qmid } \\
\text { (M3/sec) }\end{array}$ & $\begin{array}{l}\text { Qrising } \\
\left(\mathrm{TU}_{\mathrm{RL}}\right)\end{array}$ & $\begin{array}{l}\text { Qfalling } \\
\left(\mathrm{TU}_{\mathrm{FL}}\right)\end{array}$ & Season & $\mathrm{HI}$ & HD \\
\hline 2008.1 & $\begin{array}{l}10 / 15- \\
10 / 26\end{array}$ & 19.2 & 113.3 & 66.2 & 11 & 2.8 & wet & 2.93 & C \\
\hline 2008.2 & $\begin{array}{l}11 / 15- \\
11 / 26\end{array}$ & 98.5 & 186.0 & 142.3 & 9.6 & 21 & wet & -1.19 & CC \\
\hline 2008.3 & $\begin{array}{l}12 / 1- \\
12 / 16\end{array}$ & 35.1 & 501.2 & 268.2 & 63 & 38 & wet & 0.66 & C \\
\hline 2008.5 & $\begin{array}{l}5 / 14- \\
5 / 28\end{array}$ & 91.7 & 283.2 & 187.5 & 22 & 12 & dry & 0.83 & $C$ \\
\hline
\end{tabular}




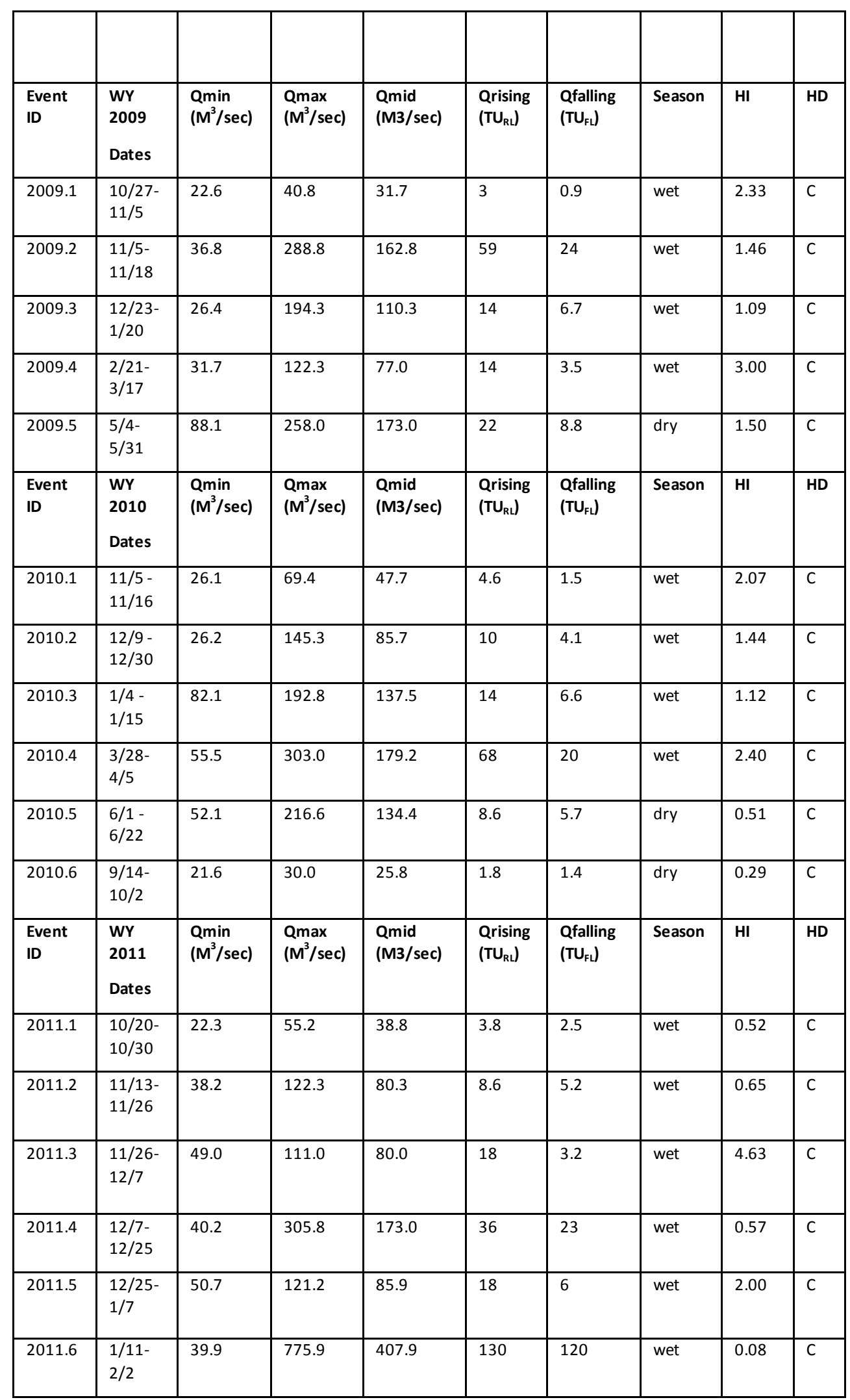




\section{Appendix F- Hysteresis Indices for Oregon City}

\begin{tabular}{|c|c|c|c|c|c|c|c|c|c|}
\hline \multicolumn{10}{|c|}{ Hysteresis Indices and Associated Data from Clackamas at Oregon City } \\
\hline $\begin{array}{l}\text { Event } \\
\text { ID }\end{array}$ & $\begin{array}{l}\text { WY } 2006 \\
\text { Dates }\end{array}$ & $\begin{array}{l}\text { Qmin } \\
\left(\mathrm{M}^{3} / \mathrm{sec}\right)\end{array}$ & $\begin{array}{l}\text { Qmax } \\
\left(\mathrm{M}^{3} / \mathrm{sec}\right)\end{array}$ & $\begin{array}{l}\text { Qmid } \\
\left(\mathrm{M}^{3} / \mathrm{sec}\right)\end{array}$ & $\begin{array}{l}\text { Qrising } \\
\text { (TURL) }\end{array}$ & $\begin{array}{l}\text { Qfalling } \\
\text { (TUFL) }\end{array}$ & Season & HI & HD \\
\hline 2006.1 & $\begin{array}{l}11 / 10- \\
11 / 24\end{array}$ & 73.1 & 186.9 & 130.0 & 4.8 & 1.4 & wet & 2.43 & $\mathrm{C}$ \\
\hline 2006.2 & $\begin{array}{l}12 / 18- \\
12 / 26\end{array}$ & 34.8 & 186.3 & 110.6 & 23 & 23 & wet & 0.00 & \\
\hline 2006.3 & \begin{tabular}{|l|}
$12 / 29-$ \\
$1 / 6$
\end{tabular} & 362.5 & 1305.4 & 833.9 & 120 & 100 & wet & 0.20 & $\mathrm{C}$ \\
\hline 2006.6 & $\begin{array}{l}1 / 27- \\
2 / 11\end{array}$ & 74.8 & 218.3 & 146.5 & 30 & 52 & wet & $\begin{array}{l}- \\
0.73\end{array}$ & $\mathrm{CC}$ \\
\hline 2006.7 & $2 / 27-3 / 5$ & 65.1 & 142.2 & 103.6 & 21 & 3.7 & wet & 4.68 & $\mathrm{C}$ \\
\hline 2006.8 & $3 / 7-3 / 12$ & 83.8 & 113.8 & 98.8 & 24 & 4.2 & wet & 4.71 & C \\
\hline 2006.9 & $4 / 2-4 / 30$ & 81.0 & 211.8 & 146.4 & 7.8 & 4.1 & Dry & 0.90 & C \\
\hline $\begin{array}{l}\text { Event } \\
\text { ID }\end{array}$ & $\begin{array}{l}\text { WY } 2007 \\
\text { Dates }\end{array}$ & $\begin{array}{l}\text { Qmin } \\
\left(\mathrm{M}^{3} / \mathrm{sec}\right)\end{array}$ & $\begin{array}{l}\text { Qmax } \\
\left(\mathrm{M}^{3} / \mathrm{sec}\right)\end{array}$ & $\begin{array}{l}\text { Qmid } \\
\text { (M3/sec) }\end{array}$ & $\begin{array}{l}\text { Qrising } \\
\left(\mathrm{TU}_{\mathrm{RL}}\right)\end{array}$ & $\begin{array}{l}\text { Qfalling } \\
\left(T_{\mathrm{FL}}\right)\end{array}$ & Season & $\mathrm{HI}$ & HD \\
\hline 2007.2 & $\begin{array}{l}12 / 8- \\
12 / 22\end{array}$ & 84.4 & 557.8 & 321.1 & 20 & 30 & Wet & $-\overline{-}$ & $\mathrm{CC}$ \\
\hline 2007.3 & \begin{tabular}{|l|}
$12 / 22-$ \\
$1 / 7$
\end{tabular} & 138.5 & 219.5 & 179.0 & 12 & 7.4 & Wet & 0.62 & $C$ \\
\hline 2007.6 & $3 / 24-4 / 1$ & 109.0 & 286.0 & 197.5 & 29 & 4.9 & Wet & 4.92 & C \\
\hline $\begin{array}{l}\text { Event } \\
\text { ID }\end{array}$ & $\begin{array}{l}\text { WY } 2008 \\
\text { Dates }\end{array}$ & $\begin{array}{l}\text { Qmin } \\
\left(\mathrm{M}^{3} / \mathrm{sec}\right)\end{array}$ & $\begin{array}{l}\mathrm{Qmax} \\
\left(\mathrm{M}^{3} / \mathrm{sec}\right)\end{array}$ & $\begin{array}{l}\text { Qmid } \\
\text { (M3/sec) }\end{array}$ & $\begin{array}{l}\text { Qrising } \\
\left(\mathrm{TU}_{\mathrm{RL}}\right)\end{array}$ & $\begin{array}{l}\text { Qfalling } \\
\left(\mathrm{TU}_{\mathrm{FL}}\right)\end{array}$ & Season & HI & HD \\
\hline 2008.1 & \begin{tabular}{|l}
$10 / 15-$ \\
$10 / 26$
\end{tabular} & 28.9 & 162.3 & 95.6 & 9.7 & 2.7 & Wet & 2.59 & C \\
\hline 2008.2 & \begin{tabular}{|l|}
$11 / 15-$ \\
$11 / 26$
\end{tabular} & 53.0 & 288.8 & 170.9 & 24 & 7 & Wet & 2.43 & C \\
\hline
\end{tabular}




\begin{tabular}{|c|c|c|c|c|c|c|c|c|c|}
\hline 2008.3 & $\begin{array}{l}12 / 1- \\
12 / 16\end{array}$ & 69.9 & 841.0 & 455.5 & 45 & 40 & Wet & 0.13 & C \\
\hline 2008.5 & $\begin{array}{l}5 / 14- \\
5 / 28\end{array}$ & 130.5 & 436.1 & 283.3 & 3.3 & 4.7 & Dry & $\overline{-}-42$ & CC \\
\hline $\begin{array}{l}\text { Event } \\
\text { ID }\end{array}$ & $\begin{array}{l}\text { WY } 2009 \\
\text { Dates }\end{array}$ & $\begin{array}{l}\text { Qmin } \\
\left(\mathrm{M}^{3} / \mathrm{sec}\right)\end{array}$ & $\begin{array}{l}\text { Qmax } \\
\left(\mathrm{M}^{3} / \mathrm{sec}\right)\end{array}$ & $\begin{array}{l}\text { Qmid } \\
\text { (M3/sec) }\end{array}$ & $\begin{array}{l}\text { Qrising } \\
\left(\mathrm{TU}_{\mathrm{RL}}\right)\end{array}$ & $\begin{array}{l}\text { Qfalling } \\
\left(\mathrm{TU}_{\mathrm{FL}}\right)\end{array}$ & Season & HD & $\mathrm{HI}$ \\
\hline 2009.1 & $\begin{array}{l}10 / 27- \\
11 / 5\end{array}$ & 26.4 & 80.1 & 2.3 & 7 & 2.3 & Wet & 2.04 & C \\
\hline 2009.2 & $\begin{array}{l}11 / 5- \\
11 / 18\end{array}$ & 48.4 & 688.1 & 368.3 & 50 & 31 & Wet & 0.61 & $\mathrm{C}$ \\
\hline 2009.3 & $\begin{array}{l}12 / 23- \\
1 / 20\end{array}$ & 35.1 & 464.4 & 249.8 & 16 & 9.4 & Wet & 0.70 & C \\
\hline 2009.4 & $\begin{array}{l}2 / 21- \\
3 / 17\end{array}$ & 45.6 & 252.3 & 148.9 & 4.2 & 8.1 & Wet & $\begin{array}{l}- \\
0.93\end{array}$ & CC \\
\hline 2009.5 & $5 / 4-5 / 31$ & 145.8 & 436.1 & 291.0 & 4.6 & 14 & Dry & $\begin{array}{l} \\
2.04\end{array}$ & CC \\
\hline $\begin{array}{l}\text { Event } \\
\text { ID }\end{array}$ & $\begin{array}{l}\text { WY } 2010 \\
\text { Dates }\end{array}$ & $\begin{array}{l}\text { Qmin } \\
\left(\mathrm{M}^{3} / \mathrm{sec}\right)\end{array}$ & $\begin{array}{l}\text { Qmax } \\
\left(\mathrm{M}^{3} / \mathrm{sec}\right)\end{array}$ & $\begin{array}{l}\text { Qmid } \\
\text { (M3/sec) }\end{array}$ & $\begin{array}{l}\text { Qrising } \\
\left(T_{R L}\right)\end{array}$ & $\begin{array}{l}\text { Qfalling } \\
\left(\mathrm{TU}_{\mathrm{FL}}\right)\end{array}$ & Season & HI & HD \\
\hline 2010.1 & $\begin{array}{l}11 / 5- \\
11 / 16\end{array}$ & 36.8 & 152.6 & 94.7 & 5.3 & 3.8 & Wet & 0.39 & C \\
\hline 2010.2 & $\begin{array}{l}12 / 9- \\
12 / 30\end{array}$ & 36.5 & 245.2 & 140.9 & 15 & 4.5 & Wet & 2.33 & C \\
\hline 2010.3 & $\begin{array}{l}1 / 4- \\
1 / 15\end{array}$ & 138.8 & 365.3 & 252.0 & 5.9 & 8.2 & Wet & $\begin{array}{l}- \\
0.39\end{array}$ & CC \\
\hline 2010.4 & $\begin{array}{l}3 / 28- \\
4 / 5\end{array}$ & 89.8 & 549.3 & 319.6 & 34 & 23 & $\begin{array}{l}\text { Wet/Dr } \\
y\end{array}$ & 0.48 & C \\
\hline 2010.5 & $\begin{array}{l}6 / 1- \\
6 / 22\end{array}$ & 109.3 & 438.9 & 274.1 & 17 & 9.4 & Dry & 0.81 & C \\
\hline 2010.6 & $\begin{array}{l}9 / 14- \\
10 / 2\end{array}$ & 20.2 & 54.7 & 37.4 & 0.9 & 1.3 & Wet & $\begin{array}{l}- \\
0.44\end{array}$ & CC \\
\hline $\begin{array}{l}\text { Event } \\
\text { ID }\end{array}$ & $\begin{array}{l}\text { WY } 2011 \\
\text { Dates }\end{array}$ & $\begin{array}{l}\text { Qmin } \\
\left(\mathrm{M}^{3} / \mathrm{sec}\right)\end{array}$ & $\begin{array}{l}\text { Qmax } \\
\left(\mathrm{M}^{3} / \mathrm{sec}\right)\end{array}$ & $\begin{array}{l}\text { Qmid } \\
\text { (M3/sec) }\end{array}$ & $\begin{array}{l}\text { Qrising } \\
\left(\mathrm{TU}_{\mathrm{RL}}\right)\end{array}$ & $\begin{array}{l}\text { Qfalling } \\
\left(\mathrm{TU}_{\mathrm{FL}}\right)\end{array}$ & Season & $\mathrm{HI}$ & HD \\
\hline 2011.2 & $\begin{array}{l}11 / 13- \\
11 / 26\end{array}$ & 72.8 & 280.9 & 176.8 & 30 & 8.4 & Wet & 2.57 & C \\
\hline 2011.3 & $\begin{array}{l}11 / 26- \\
12 / 7\end{array}$ & 69.9 & 294.5 & 182.2 & 11 & 4.9 & Wet & 1.24 & C \\
\hline 2011.4 & $\begin{array}{l}12 / 7- \\
12 / 25\end{array}$ & 85.8 & 753.2 & 419.5 & 43 & 31 & Wet & 0.39 & C \\
\hline 2011.5 & $\begin{array}{l}12 / 25- \\
1 / 7\end{array}$ & 85.2 & 390.8 & 238.0 & 35 & 12 & Wet & 1.92 & C \\
\hline 2011.6 & $1 / 11-2 / 2$ & 68.8 & 1557.4 & 813.1 & 59 & 120 & Wet & $\begin{array}{l}- \\
1.03\end{array}$ & CC \\
\hline
\end{tabular}




\begin{tabular}{|c|c|c|c|c|c|c|c|c|c|}
\hline 2011.7 & $\begin{array}{l}4 / 14- \\
4 / 24\end{array}$ & 132.8 & 351.1 & 242.0 & 4.6 & 7.9 & Dry & $\begin{array}{l}- \\
0.72\end{array}$ & CC \\
\hline $\begin{array}{l}\text { Event } \\
\text { ID }\end{array}$ & $\begin{array}{l}\text { WY } 2012 \\
\text { Dates }\end{array}$ & $\begin{array}{l}\text { Qmin } \\
\left(M^{3} / \mathrm{sec}\right)\end{array}$ & $\begin{array}{l}\text { Qmax } \\
\left(M^{3} / \mathrm{sec}\right)\end{array}$ & $\begin{array}{l}\text { Qmid } \\
\text { (M3/sec) }\end{array}$ & $\begin{array}{l}\text { Qrising } \\
\left(\mathrm{TU}_{\mathrm{RL}}\right)\end{array}$ & $\begin{array}{l}\text { Qfalling } \\
\left(\mathrm{TU}_{\mathrm{FL}}\right)\end{array}$ & Season & HI & HD \\
\hline 2012.2 & $\begin{array}{l}11 / 21- \\
12 / 26\end{array}$ & 53.2 & 228.8 & 141.0 & 13 & 7.1 & Wet & 0.83 & C \\
\hline 2012.3 & $\begin{array}{l}12 / 27- \\
1 / 16\end{array}$ & 35.4 & 906.1 & 470.8 & 110 & 82 & Wet & 0.34 & C \\
\hline 2012.4 & $\begin{array}{l}1 / 17- \\
2 / 10\end{array}$ & 69.7 & 1226.1 & 647.9 & 65 & 36 & Wet & 0.81 & C \\
\hline 2012.5 & $2 / 17-3 / 3$ & 105.3 & 373.8 & 239.6 & 5.3 & 8.9 & Wet & $\begin{array}{l}- \\
0.68\end{array}$ & CC \\
\hline 2012.6 & $3 / 9-3 / 27$ & 132.0 & 727.7 & 429.8 & 21 & 25 & Wet & $\begin{array}{l}- \\
0.19\end{array}$ & $\mathrm{CC}$ \\
\hline 2012.7 & $\begin{array}{l}3 / 29- \\
4 / 10\end{array}$ & 152.6 & 909.0 & 530.8 & 30 & 35 & $\begin{array}{l}\text { Wet/Dr } \\
y\end{array}$ & $\begin{array}{l}- \\
0.17\end{array}$ & $\mathrm{CC}$ \\
\hline 2012.8 & $\begin{array}{l}4 / 15- \\
5 / 13\end{array}$ & 132.8 & 305.8 & 219.3 & 5.9 & 5.8 & Dry & 0.02 & $\mathrm{C}$ \\
\hline \multicolumn{10}{|c|}{$\begin{array}{l}\text { Event- water year and storm number of that water year, WY-water year, } \mathrm{M}^{3} / \mathrm{sec} \text {-cubic meters per second, } \\
\mathrm{Q}_{\min } \text {-discharge at the start of storm event, } \mathrm{Q}_{\mathrm{max}} \text {-peak discharge of storm event, } \mathrm{Q}_{\mathrm{mid}} \text {-discharge at the } \\
\text { midpoint of storm event, } \mathrm{TU}_{\mathrm{RL}} \text {-turbidity at the midpoint on the rising limb of the hydrograph, } \mathrm{TU}_{\mathrm{FL}} \\
\text { turbidity at the midpoint on the falling limb of the hydrograph, HI-hysteresis index, } \mathrm{HD} \text {-hysteresis } \\
\text { direction, C-clockwise hysteresis (turbidity higher on rising limb of storm hydrograph), CC-counter } \\
\text { clockwise hysteresis (turbidity higher on the falling limb of the storm hydrograph) }\end{array}$} \\
\hline
\end{tabular}


Appendix G-Shapiro-Wilk Test for Normality Results for Change in Turbidity Final Model Variables and Residuals

\begin{tabular}{|l|c|r|}
\hline \multicolumn{3}{|c|}{$\begin{array}{l}\text { Shapiro-Wilk Test Results } \\
\text { for Carter Bridge }\end{array}$} \\
\hline Site/Parameter & $\begin{array}{l}\text { Shapiro- } \\
\text { Wilk } \\
\text { (SW) }\end{array}$ & $\begin{array}{l}\text { SW p- } \\
\text { value }\end{array}$ \\
\hline $\begin{array}{l}\text { Carter Bridge } \\
\text { (Log } \Delta \mathrm{Q})\end{array}$ & 0.9545 & 0.1087 \\
\hline $\begin{array}{l}\text { Carter Bridge } \\
\text { (Log } \Delta \mathrm{Tb})\end{array}$ & 0.9242 & $\begin{array}{r}0.0104 \\
8\end{array}$ \\
\hline $\begin{array}{l}\text { Linear Model } \\
\text { Residuals }\end{array}$ & 0.9081 & 0.0332 \\
\end{tabular}

\begin{tabular}{|l|l|l|}
\hline \multicolumn{3}{|l|}{ Shapiro-Wilk Test Results for Oregon } \\
City
\end{tabular}

